\author{
UNIVERSIDADE DE SÃO PAULO \\ INSTITUTO DE BIOCIÊNCIAS \\ INSTITUTO DE FÍSICA \\ INSTITUTO DE QUÍMICA \\ FACULDADE DE EDUCAÇÃO
}

Ser mulher em Ciências da Natureza e Matemática

Renata Rosenthal

São Paulo

2018 
RENATA ROSENTHAL

Ser mulher em Ciências da Natureza e Matemática

Versão Original

Dissertação apresentada ao Programa de Pós-Graduação Interunidades em Ensino de Ciências da Universidade de São Paulo, como parte das exigências para a obtenção do título de Mestrado.

Orientadora: Profa. Dra. Daisy de Brito Rezende

São Paulo

2018 
Autorizo a reprodução e divulgação total ou parcial deste trabalho, por qualquer meio convencional ou eletrônico, para fins de estudo e pesquisa, desde que citada a fonte.

FICHA CATALOGRÁFICA

Preparada pelo Serviço de Biblioteca e Informação do Instituto de Física da Universidade de São Paulo

Rosenthal, Renata

Ser mulher em Ciências da Natureza e Matemática.

São Paulo, 2018.

Dissertação (Mestrado) - Universidade de São Paulo. Faculdade de Educação, Instituto de Física, Instituto de Química e Instituto de Biociências

Orientador: Profa. Dra. Daisy de Brito Rezende

Área de Concentração: Ensino de Química

Unitermos: 1. Química - Estudo e Ensino; 2. Mulheres na ciência; 3. Gêneros (Grupos sociais); 4. Educação.

USP/IF/SBI-006/2018 


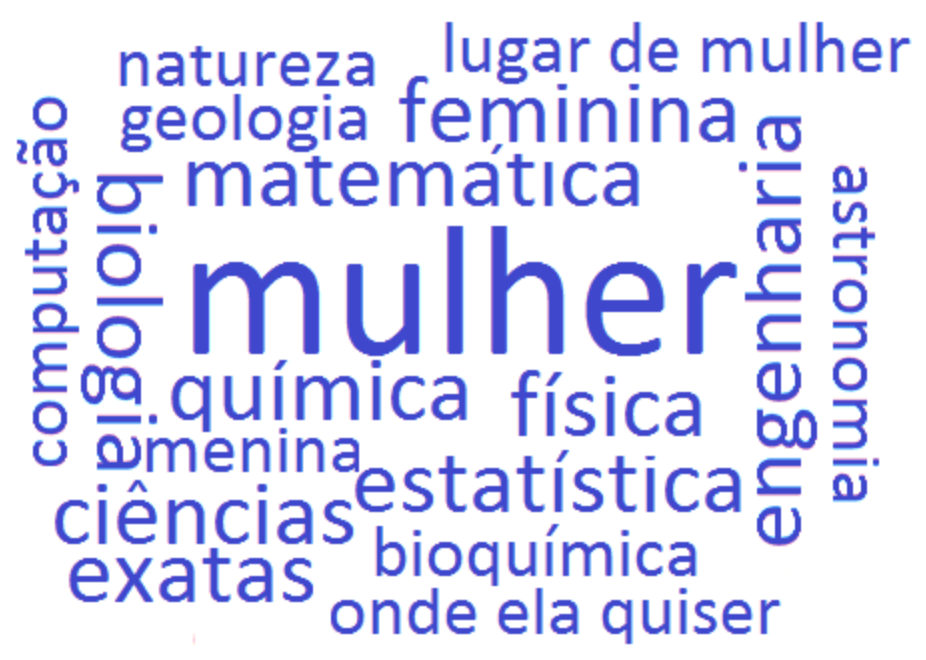

A todas as mulheres. 


\section{Homenagem e agradecimentos}

Gostaria de homenagear, neste trabalho, Ana Rosa Kucinski Silva, professora do Instituto de Química (IQ) da Universidade de São Paulo, que lutou contra a Ditadura Militar brasileira e desapareceu em 1974. Além de referência de luta e de química mulher durante toda a minha Graduação no IQ-USP, a história de Ana Rosa me tocou e me toca profundamente até hoje. Ela também era amiga dos meus tios, Abrahão e Sophia Szarfarc: ele falecido ator, e ela também química do IQ-USP, a quem deixo sinceros agradecimentos por ter me contado sua história de amizade com Ana Rosa.

Agradeço aos meus pais, Mauro e Márcia, e aos meus irmãos, Rafael e Bruno, por todo o apoio desde sempre.

Ao Leandro, meu companheiro, que me mostra a vida a partir da primeira pessoa do plural.

À professora Daisy B. Rezende, minha orientadora, que desde o início me deixou segura e confiou em meu trabalho, que é mais que uma realização profissional ou acadêmica, é uma realização pessoal.

Ao professor Mikiya Muramatsu pela acolhida logo que ingressei no Programa Interunidades; ainda que depois eu tenha mudado de ideia quanto ao tema de trabalho e tenha buscado outra orientação, foi muito importante esse primeiro contato.

Às professoras Maria Eulina P. Carvalho e Cynthia P. Sousa pelas contribuições valiosas na qualificação e na defesa. A professora Maria Eulina ainda contribuiu também em dois trabalhos que apresentei em congressos; e professora Cynthia, coordenando o grupo de estudos Formações: leituras comparadas em Ciência, Gênero e Educação na Faculdade de Educação da USP, foi essencial nessa trajetória.

À professora Marília P. Carvalho, que por meio da disciplina Relações de Gênero e Educação Escolar, me ensinou muito e me "iniciou" academicamente nessas teorias em que tanto me envolvi. Às professoras Barbara C. S. Pinheiro, Katemari D. Rosa, Christina Brech e Márcia C. B. Barbosa, grandes referências de estudiosas da questão de gênero nas Ciências da Natureza e Exatas.

Às professoras entrevistadas que aceitaram participar desse estudo e contribuíram com suas vozes e histórias de vida tão valiosas. 
Aos colegas de grupo de pesquisa, Thaiara, Luiz Guilherme, Camila, Marcos, e de outros grupos de pesquisa também, Magô, Priscila, Mauritz e Fernanda, pelas inúmeras trocas produtivas e referências acadêmicas nesse caminho.

Ao coletivo Existimos, de alunas do IME-USP, em especial Bartira, Ana Luiza e Luciana, que me ensinaram verdadeiramente o que é sororidade.

À Raphaela, que além de grande amiga, é minha referência intelectual e pessoal.

Às amigas Daniela, Camila e Vivian, que me deram um empurrão crucial nos momentos em que achei que não conseguiria, e Thais e Marcel que, além de grandes amigos, me deram muito apoio e me ajudaram muito no trabalho.

Às muitas amigas, amigos e colegas de trabalho que tenho a sorte de ter por perto e que são essenciais na minha trajetória. A todas/os as/os colaboradoras/es que, de alguma forma, contribuíram para que este trabalho saísse da forma.

"Daquelas que cantan as pombas $i$ as frores, Todos din que teñen alma de muller Pois eu que n'as canto, virxe da Paloma ¡Ai!, ¿ de que a terei?’ Rosalía de Castro 


\section{RESUMO}

ROSENTHAL, R. Ser mulher em Ciências da Natureza e Matemática. 2018. 106 p. Dissertação (Mestrado Interunidades em Ensino de Ciências) - Instituto de Biociências, Instituto de Física, Instituto de Química e Faculdade de Educação - Universidade de São Paulo, São Paulo, 2018.

Estudos do Instituto Brasileiro de Geografia e Estatística (IBGE) mostram que as mulheres ainda ganham menos do que os homens no mercado de trabalho: $76,1 \%$ da renda deles ${ }^{1}$. $O$ relatório do Fórum Econômico Mundial de 2017 (acrônimo do inglês, WEF) mostrou que a desigualdade entre homens e mulheres voltou a crescer, em 2017, considerando-se quatro pilares - trabalho, educação, política e saúde - e que só seria possível alcançar a igualdade de gênero no país em cerca de 217 anos (o Brasil ocupa a nonagésima posição em relação à paridade de gênero nesses campos em uma classificação hierárquica em que se analisaram 144 países $^{2}$ ). As mulheres passaram séculos proibidas de exercer seus direitos como cidadãs, de exercer atividades remuneradas fora do lar, de estudar e, apesar de no fim do século XIX elas terem começado a ingressar nas universidades, há áreas, como as das Ciências da Natureza, Tecnologias, Engenharias e Matemática, nas quais, até hoje, a quantidade de mulheres não é significativa. Houve um aumento do número de mulheres nessas áreas no Brasil, mas elas ainda são minoria tanto no Brasil quanto no restante do mundo $^{3} \mathrm{e}$, conforme se avança na hierarquia da carreira, esse número cai significativamente. Considerando esse cenário, o presente trabalho buscou entender quais fatores têm contribuído para a permanência dessa minoria de mulheres nas carreiras científicas, pensando também no afastamento delas da área, desde os passos iniciais da carreira profissional. Para tanto, realizaram-se nove coletas de narrativas de vida de cientistas pesquisadoras universitárias de vários ramos das Ciências da Natureza e da Matemática. A partir destes relatos autobiográficos, empregou-se uma ferramenta computacional (IRAMUTEQ) aos textos transcriados que gera estatísticas textuais das palavras mais citadas e as relaciona em pares. Para a atribuição de significado a estas

\footnotetext{
1 Disponível em:

$<$ https://agenciadenoticias.ibge.gov.br/agencia-noticias/2013-agencia-de-noticias/releases/9461-pnad2015-rendimentos-tem-queda-e-desigualdade-mantem-trajetoria-de-reducao.html>. Acesso em: 21 jan. 2018.

2 Disponível em:

$<$ http://reports.weforum.org/global-gender-gap-report-2017/dataexplorer/\#economy=BRA>. Acesso em: 01 dez. 2017.

${ }^{3}$ Disponível em: <http://unesdoc.unesco.org/images/0023/002354/235406e.pdf>. Acesso em: 21 jul. 2017.
} 
palavras, dependente do contexto de cada narração, procedeu-se a uma análise de conteúdo (na perspectiva francesa) segundo contornos delimitados pela revisão de diversos trabalhos sobre a temática. Em todas as entrevistas analisadas, evidenciou-se que um dos pares de palavras relacionadas mais citado pelas narradoras é "não" e "mulher" que, em conjunto com outras interpretações de falas destas mulheres, sugere que o sentido da negação da própria "feminilidade" não se refira à mudança de suas identidades, mas a uma possível negação do "lugar de mulher" estabelecido na sociedade como mecanismo de permanência na carreira profissional, inclusive a científica. A perspectiva do presente trabalho é a de propor reflexões acerca do que se pode fazer para colaborar para uma educação mais igualitária, incluindo potenciais ações que incentivem meninas a se interessarem pelas Ciências e as mulheres a permanecerem profissionalmente nesse campo. Essas ações devem contribuir para a quebra de estereótipos e preconceitos, visando à construção de uma sociedade mais justa.

Palavras-chave: gênero, ciência, educação, mulheres. 
ROSENTHAL, R. To be a woman in Sciences and Mathematics. 2018. 106 p. Dissertação (Mestrado Interunidades em Ensino de Ciências) - Instituto de Biociências, Instituto de Física, Instituto de Química e Faculdade de Educação - Universidade de São Paulo, São Paulo, 2018.

The Brazilian Institute of Geography and Statistics (Portuguese acronym from IBGE) has recently shown that women still earn less than men in the labor market: $76.1 \%$ of their income $^{1}$. A report by the 2017 World Economic Forum $\left(\mathrm{WEF}^{2}\right)$ showed that inequality between men and women regarding four pillars - work, education, politics, and health - has grown again that year. The same report states it would take at least 217 years, in Brazil, to achieve gender equality (Brazil is in the 90th position in the ranking of 144 countries in gender parity). For centuries, women have been prohibited from exerting their rights as citizens, which includes studying and working outside their homes. Although they have begun to enter universities by the end of the nineteenth century, areas such as Sciences and Mathematics lack the presence of women so far. An increase in the number of women in these areas has been observed in Brazil, even though they remain a minority both in Brazil ${ }^{3}$ and in the rest of the world and, as the career hierarchy progresses, this number drops significantly. This scenario leads to the development of this Master research that intends to unveil the factors that contribute to the permanence of a minority of women in the scientific career, also considering their distancing from this area since a very early age. For that, we carried out nine life narratives with female scientists. Based on these autobiographical narratives, we employed a computational tool (IRAMUTEQ) that performs a textual statistic to get the most cited pairs of words in the interview. The attribution of meaning to these word pairs depended on the context of each transcribed narration and was done by content analysis (as developed in the French perspective) within the limits of the literature review. Out of the set of analyzed interviews, one of the most quoted pairs of related words by the narrators is "no" and "woman". One possible interpretation of this connection is the denial of "femininity" itself, not in the sense of a change in their identities, but instead as a rejection

\footnotetext{
${ }^{1}$ Retrieved from:

<https://agenciadenoticias.ibge.gov.br/agencia-noticias/2013-agencia-de-noticias/releases/9461-pnad2015-rendimentos-tem-queda-e-desigualdade-mantem-trajetoria-de-reducao.html> (2018, jan 21).

${ }^{2}$ Retrieved from:

<http://reports. weforum.org/global-gender-gap-report-2017/dataexplorer/\#economy=BRA> (2017, dez. $01)$.

${ }^{3}$ Retrieved from: <http://unesdoc.unesco.org/images/0023/002354/235406e.pdf> (2017, jul 21).
} 
towards the social representation of "a woman's place" established nowadays in our society. This mechanism of permanence in the career allows understanding the character of the apparent gender rejection perceived. In this way, the work sought to promote reflections about what can be done to transform education, through the implementation of actions which deal with the breakdown of stereotypes and prejudices. These changes should lead to the construction of a fair world and to the encouragement of girls to enjoy Sciences and Mathematics, and the women to embrace STEM ${ }^{4}$ careers.

Keywords: gender, sciences, education, woman.

${ }^{4}$ Science, Technology, Engineering, and Mathematics. 


\section{LISTA DE FIGURAS}

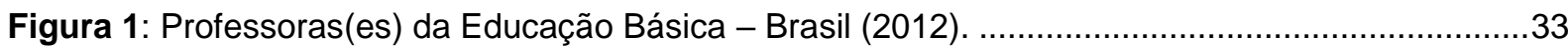

Figura 2: Árvore obtida a partir da análise de similitude do relato de Alice. .........................................66

Figura 3: Árvore obtida a partir da análise de similitude do relato de Annie.......................................68

Figura 4: Árvore obtida a partir da análise de similitude do relato de Enedina. ...................................70

Figura 5: Árvore obtida a partir da análise de similitude do relato de Grace. ........................................72

Figura 6: Árvore obtida a partir da análise de similitude do relato de Juliana. ...................................73

Figura 7: Árvore obtida a partir da análise de similitude do relato de Nagwa......................................76

Figura 8: Árvore obtida a partir da análise de similitude do relato de Nise..........................................77

Figura 9: Árvore obtida a partir da análise de similitude do relato de Rosalind. ...................................79

Figura 10: Árvore obtida a partir da análise de similitude do relato de Stephanie...............................81

Figura 11: Árvore obtida a partir da análise de similitude de um único texto com todos os relatos.....82 


\section{LISTA DE QUADROS}

Quadro 1: Disciplinas cursadas na USP durante o tempo de Mestrado.........................................17

Quadro 2: Caracterização profissional das mulheres entrevistadas....................................................56

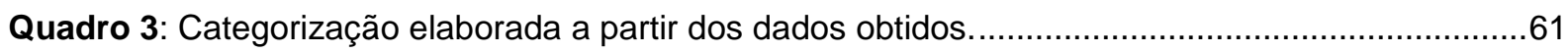

Quadro 4: Categorização de termos a partir dos relatos sobre a escolha profissional das entrevistadas

Quadro 5: Categorização de termos a partir dos relatos sobre a permanência na carreira das entrevistadas.

Quadro 6: Categorização de termos a partir dos relatos sobre momentos marcantes na carreira das entrevistadas.

Quadro 7: Caracterização das entrevistadas em relação à idade, estado civil e ano de titulação.

Quadro 8: Exemplos de desenhos elaborados pelos alunos, nos quais o cientista é um homem......104

Quadro 9: Exemplos de desenhos elaborados pelas crianças, nos quais a cientista é mulher .105

Quadro 10: Exemplos de desenhos elaborados pelos alunos nos quais as mulheres são assistentes do cientista.

Quadro 11: Exemplos de desenhos nos quais o cientista não tem gênero definido. 106 


\section{LISTA DE TABELAS}

Tabela 1: Distribuição de matrículas em cursos de Graduação em função do gênero. .33

Tabela 2: Porcentagem de mulheres Graduadas em quatro campos de conhecimento, em 2012. ....34 


\section{SUMÁRIO}

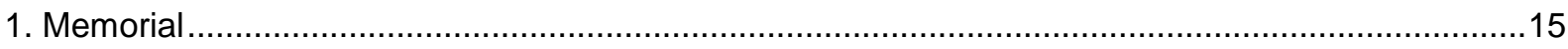

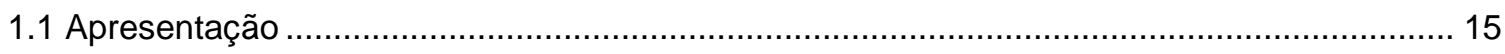

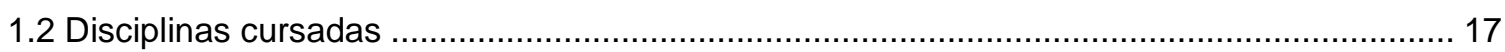

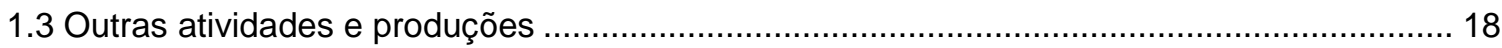

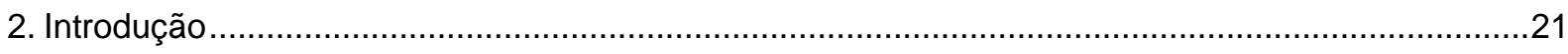

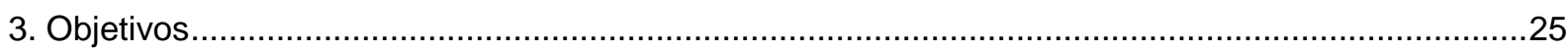

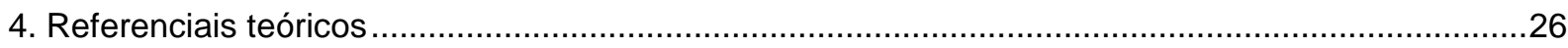

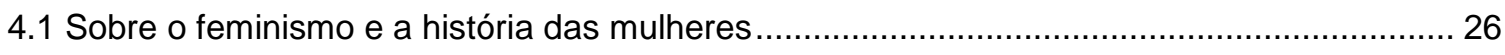

4.2 Mulheres no Ensino Superior e a violência simbólica ............................................................ 29

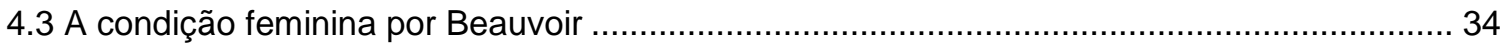

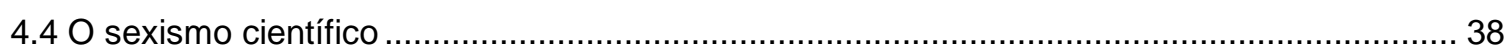

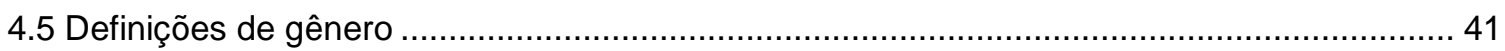

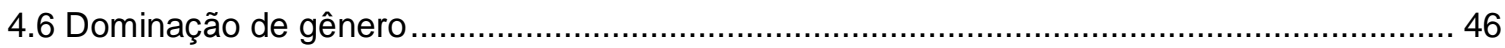

4.7 O sexismo nas Ciências da Natureza e Exatas - Efeito Matilda............................................. 49

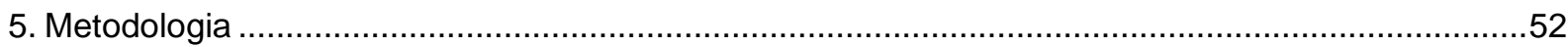

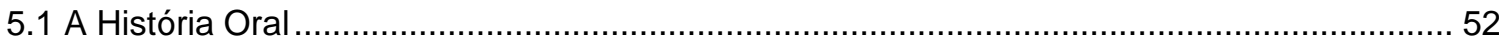

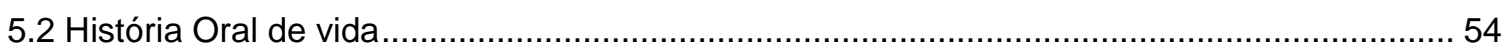

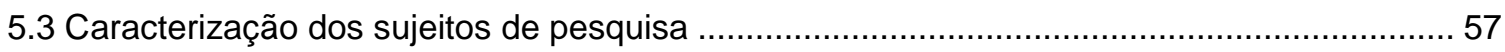

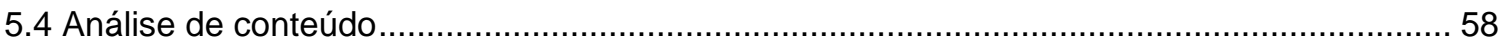

5.5 Estatísticas textuais como ferramenta na análise de conteúdo............................................ 59

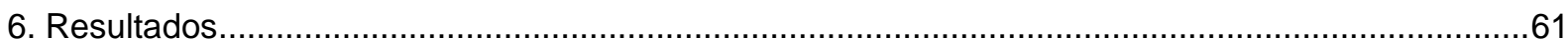

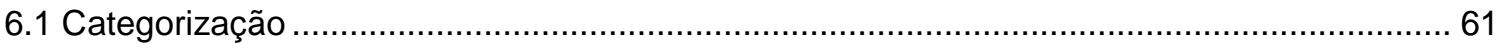

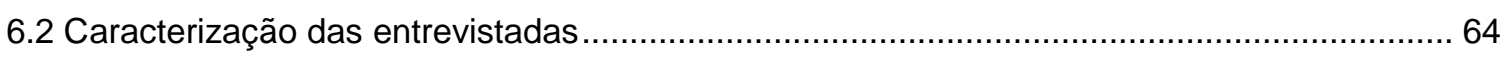

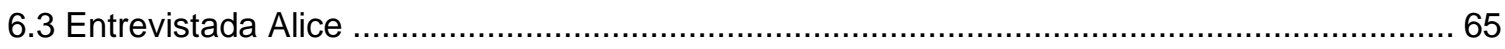

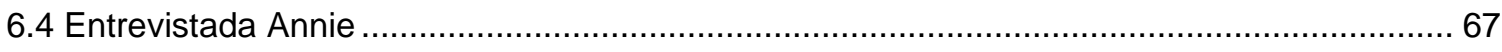

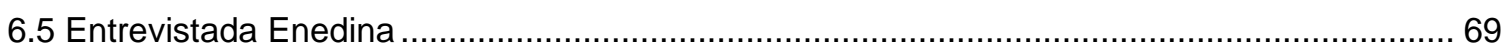

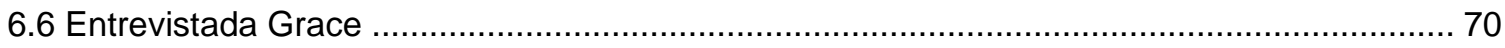

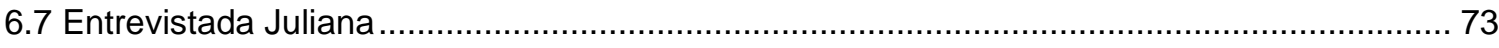

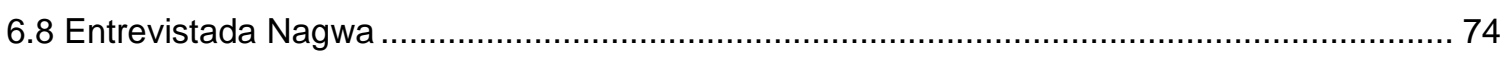

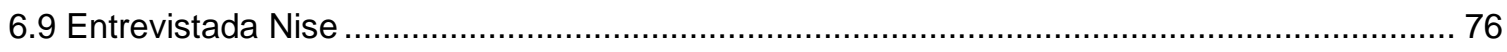

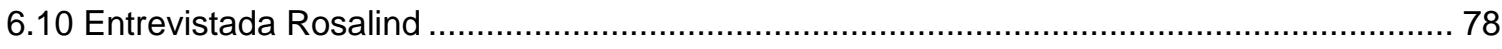

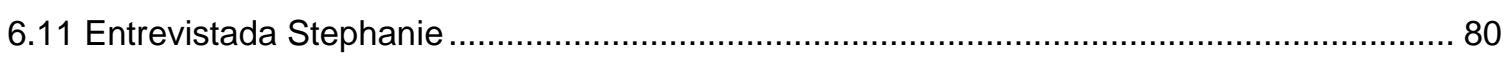

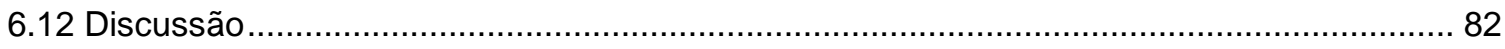

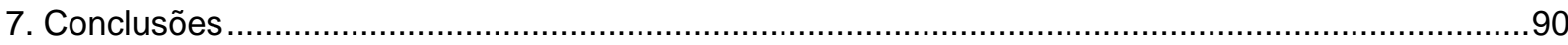

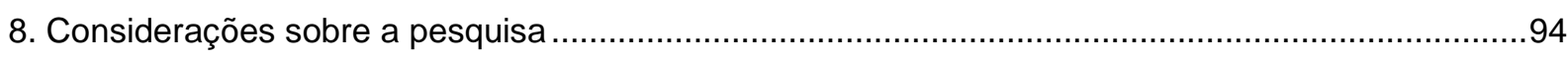

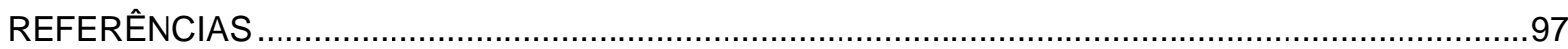

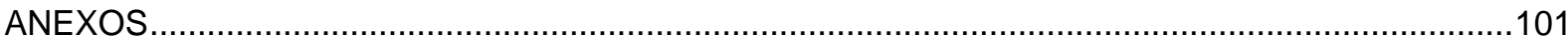




\section{Memorial}

\subsection{Apresentação}

Meu percurso até chegar à atual pesquisa apresentou diversas fases. Durante minha trajetória escolar, me aproximei muito das Ciências Humanas, principalmente Literatura e Redação. Cheguei a pensar em cursar Letras, Psicologia ou Jornalismo, mas minha paixão pelas Ciências da Natureza e Exatas sempre se destacou, talvez por influência dos meus pais, que, apesar de não terem concluído o Ensino Superior, sempre se identificaram muito com essas áreas.

Os professores que me deram aula no Ensino Médio contribuíram para essa paixão pelas Ciências da Natureza e Exatas aumentar e um professor de Química em especial, Caio, me incentivou muito à aproximação da Química. A decisão pela área de Educação também foi tomada antes mesmo de meu ingresso no curso; eu adorava estudar com os amigos, explicando conteúdos em que eu me sentia segura e, esse mesmo professor, perguntou um dia: "Você quer dar aula?". Eu disse: "Quero". Ele então respondeu: "Vou começar a te indicar para algumas aulas". E isso aconteceu logo que saí do Ensino Médio.

Sempre ficava muito nervosa em situações de avaliações e, apesar de todo o esforço e de todo o estudo, demorei ainda mais dois anos para passar no vestibular do curso de Química da Universidade de São Paulo (USP). Naquele ano do ingresso, eu já tinha dois anos de experiência dando aulas particulares e fui convidada pelo Caio para trabalhar em um colégio como plantonista de dúvidas. E, assim, segui toda a Graduação trabalhando na área de Educação, parte dela dando aulas, parte dela trabalhando com materiais didáticos de Química e Ciências, oportunidade que surgiu ao longo do meu percurso um pouco mais tarde.

Muitas dúvidas surgiram ao longo da Graduação, além de ter sido difícil trabalhar tanto quanto eu trabalhava junto com os estudos, o que fez com que eu ficasse nesse estágio muito mais tempo do que o previsto. Me perguntava se estava no lugar certo; muitas vezes não me sentia parte do Instituto de Química, mas a Educação ainda me fazia seguir.

Terminei a Graduação em 2014 com muito "suor", certa de que queria seguir os estudos em uma área mais ampla, que ainda falasse de Química ou de outras áreas das Ciências da Natureza, mas que me fizesse sentir parte dela, ou, ainda, que me estimulasse 
a permanecer nela. A decisão foi trabalhar, inicialmente, com Divulgação Científica, área que conheci em 2012 em um congresso. Lá me apaixonei pela possibilidade de mostrar as Ciências da Natureza e Exatas para as pessoas, aproximar quem jamais imaginava que essas áreas poderiam ser interessantes; de maneira geral, torná-las acessíveis para todos e todas.

Assim, ingressei, em 2015, no Programa de Pós-Graduação Interunidades em Ensino de Ciências (PIEC) com essa intenção de trabalho de Mestrado, só que, por diversos motivos, demorei a pensar e definir verdadeiramente o tema de pesquisa para essa etapa.

Algumas experiências pessoais com questões de gênero já me moviam há muitos anos. Sempre me perguntei por que mulheres eram tratadas de forma diferente na religião (tive criação judaica), nas relações afetivas, na mídia, na escola, na sociedade como um todo e, mais ainda, me questionava como mulher, buscava encontrar meu lugar e papel na sociedade.

Em outubro de 2015, fui assistir à estreia de um documentário de uma grande amiga (VOZERIA, 2015), que articula reflexões sobre gênero e sexualidade. Além da amizade que tenho com a idealizadora e diretora do filme, Raphaela, estar ali naquele dia me tocou muito. As questões de gênero tratadas no documentário são, na verdade, parte importante das reflexões que eu vinha fazendo há anos sobre o meu real espaço na sociedade como mulher. $\mathrm{E}$, ali, me questionei sobre como poderia unir a vida de cientista às questões sobre a mulher na sociedade. Percebi que, mais do que apresentar as Ciências da Natureza e Exatas para as pessoas, que era minha intenção inicial ao ingressar no Mestrado, eu gostaria de aproximá-la das mulheres; mais do que tornar essas temáticas acessíveis, eu queria entender por que há menor número de mulheres dedicadas a essas áreas do conhecimento, quais seriam as relações de gênero envolvidas na baixa procura das mulheres por essas áreas, quais seriam as relações entre os diversos tipos de violência contra as mulheres e esse afastamento delas dessas áreas.

Além disso, também fiz relações com a minha trajetória. Afinal, o que é que me afastava da área? Por que eu sentia com tanta frequência que não fazia parte dela? Comecei a resgatar em minha memória diversas situações tanto da vida acadêmica e profissional, quanto pessoal, e passei, então, a pensar em conversar com outras mulheres sobre o assunto.

Desde então, além de alterar meu projeto de pesquisa e recomeçar meus estudos no final de 2015, me envolvi em diversos outros trabalhos. Além da pesquisa em estudos de gênero, fiz parte do coletivo feminista "Existimos", composto por alunas do Instituto de 
Matemática e Estatística da USP e participei, também, do grupo de estudos Formações: leituras comparadas em Ciência, Gênero e Educação, coordenado pela Professora Cynthia Pereira de Sousa na Faculdade de Educação da USP. Ainda, tenho participado de diversos eventos, tais como: reuniões, rodas de conversa, palestras, seminários, encontros e mesasredondas sobre as questões de gênero. Sempre que possível, tenho apresentado trabalhos e me dado voz, como mulher e cientista, acerca deste tema ainda pouco abordado.

\subsection{Disciplinas cursadas}

\begin{tabular}{|c|l|c|r|r|r|c|}
\hline Sigla & \multicolumn{1}{|c|}{$\begin{array}{c}\text { Nome da } \\
\text { disciplina }\end{array}$} & Período & $\begin{array}{c}\text { Carga } \\
\text { horária }\end{array}$ & $\begin{array}{c}\text { Créd } \\
\cdot\end{array}$ & Freq. & Conc. \\
\hline ECQ5711 & $\begin{array}{l}\text { Introdução à } \\
\text { Química } \\
\text { Computacional }\end{array}$ & $\begin{array}{c}03 / 03 \mathrm{a} \\
15 / 06 / 15\end{array}$ & 90 & 6 & 100 & $\mathrm{~A}$ \\
\hline ECF5701 & $\begin{array}{l}\text { Seminários } \\
\text { Gerais de } \\
\text { Ensino de } \\
\text { Ciências I }\end{array}$ & $\begin{array}{c}10 / 03 \mathrm{a} \\
22 / 06 / 15\end{array}$ & 30 & 2 & 100 & $\mathrm{~A}$ \\
\hline EDF5099 & $\begin{array}{l}\text { Temas de } \\
\text { Psicanálise e } \\
\text { Educação }\end{array}$ & $\begin{array}{c}13 / 03 \mathrm{a} \\
04 / 06 / 15\end{array}$ & 120 & 8 & 90 & $\mathrm{~A}$ \\
\hline EDA5030 & $\begin{array}{l}\text { Relações de } \\
\text { Gênero e } \\
\text { Educação } \\
\text { Escolar }\end{array}$ & $\begin{array}{c}02 / 03 \mathrm{a} \\
03 / 06 / 16\end{array}$ & 120 & 8 & 92 & $\mathrm{~A}$ \\
\hline ECQ5705 & $\begin{array}{l}\text { Conceitos } \\
\text { Fundamentais } \\
\text { em Química } \\
\text { Orgânica }\end{array}$ & $\begin{array}{c}17 / 03 \mathrm{a} \\
29 / 06 / 17\end{array}$ & 90 & 6 & 100 & $\mathrm{~A}$ \\
\hline Total de \\
créditos
\end{tabular}

Quadro 1: Disciplinas cursadas na USP durante o tempo de Mestrado (sistema Janus -

http://uspdigital.usp.br/janus). 


\subsection{Outras atividades e produções}

Desde o ingresso no PIEC, em 2015, participei de diversos eventos:

- Participação, como convidada, em mesa-redonda sobre Gênero e Educação em aula do curso de Licenciatura em Educomunicação - ECA (USP) - 08/2017.

- Apresentação de trabalho (comunicação oral) no 13 Mundo de Mulheres (Women's Worlds) e Fazendo Gênero 11 - UFSC - 08/2017.

- Apresentação de trabalho (pôster) no XI ENPEC - Encontro Nacional de Pesquisa em Ensino de Ciências - UFSC - 07/2017.

- Ouvinte da mesa-redonda sobre lançamento de livro Breve história do feminismo no Brasil e outros ensaios da Maria Amélia de Almeida Teles - Grupo de Estudos e Pesquisas sobre Educação e Diferenciação Sociocultural (GEPEDISC) - Faculdade de Educação da Unicamp (SP) - 06/2017.

- Participação, como convidada, em mesa-redonda sobre Mulheres na Ciência, evento para professores, coordenadores e alunos do Ensino Médio - Escola da Vila (SP) - 06/2017.

- Participação no curso Feminismo Existencialista de Simone de Beauvoir. Docente: Djamila Ribeiro. Carga horária: 8 horas - Espaço Cult (SP) - 05/2017.

- Participação no curso Introdução à análise de dados textuais assistida pelo software IRAMUTEQ. Docente: Brigido Vizeu Camargo. Carga horária: 12 horas - Fundação Carlos Chagas (SP) - 05/2017.

- Ouvinte do XII EPIEC - Encontro da Pós-Graduação Interunidades em Ensino de Ciências - USP - 04/2017.

- Participação, como convidada, da Semana de Gênero da EMEF Amorim Lima (SP), ministrando palestra para pais, professores e comunidade, rodas de conversa com duas salas de $8^{\circ}$ e $9^{\circ}$ anos e oficinas com três salas de $6^{\circ}$ ano. Todas as atividades abordaram a questão de gênero na sociedade e, mais especificamente, a questão das mulheres nas Ciências da Natureza e Exatas 10/2016.

- Participação, como convidada, em mesa-redonda sobre Mulheres na Matemática, evento da Semana da Licenciatura (SELIC) do IME (USP) para alunos e professores da Graduação - 10/2016.

- Ouvinte da mesa-redonda Mulheres nas Carreiras Científicas - Fundação Carlos Chagas (SP) - 09/2016. 
- Apresentação de trabalho (pôster) no XVIII ENEQ - Encontro Nacional de Ensino de Química - UFSC - 07/2016.

- Apresentação de trabalho (comunicação oral) no XIX REDOR - Encontro Internacional da Rede Feminista Norte e Nordeste de Estudos e Pesquisas sobre Mulher e Relações de Gênero - UFS (SE) - 06/2016.

- Ouvinte da mesa-redonda Mulheres nas Ciências Exatas - IME (USP) 05/2016; 03/2016.

- Apresentação de trabalho (comunicação oral) no XI EPIEC - Encontro da PósGraduação Interunidades em Ensino de Ciências - USP - 03/2016.

- Ouvinte da II Conferência Brasileira de Mulheres na Física - CBPF (RJ) $11 / 2015$.

Outros projetos, comissões e coletivos:

- Participação da Comissão Eleitoral de Representação Discente do Programa de Pós-Graduação Interunidades em Ensino de Ciências (PIEC-USP) - 06/2017 a $10 / 2017$.

- Integrante do Coletivo Existimos de alunas do Instituto de Matemática e Estatística (IME) da USP - 03/2016 a 06/2017.

- Participação da Comissão de Seleção do Processo Seletivo (2017) de Mestrado do Programa de Pós-Graduação Interunidades em Ensino de Ciências (PIECUSP) - 09/2016 a 12/2016.

- Participação no Projeto Pós-Graduandos na Escola da Faculdade de Educação da Universidade de São Paulo (FE-USP). O Projeto é constituído por vários outros planos de oficinas/palestras/vivências a serem aplicadas em escolas públicas de São Paulo. A minha intervenção propôs incentivar as meninas de Ensino Fundamental ao interesse pelas carreiras científicas - 08/2016 a $12 / 2016$.

Publicações em 2016 e 2017:

ROSENTHAL, R.; REZENDE, D. B. Mulheres cientistas: um estudo sobre os estereótipos de gênero das crianças acerca de cientistas. In: MUNDO DE MULHERES E FAZENDO GÊNERO, 13 e 11, Florianópolis, 2017. Anais. Florianópolis: Universidade Federal de Santa Catarina, s.d. 
ROSENTHAL, R.; REZENDE, D. B. É possível ser mulher na Ciência?. In: ENCONTRO NACIONAL DE PESQUISA EM ENSINO DE CIÊNCIAS, 11, Florianópolis, 2017. Anais. Florianópolis: Universidade Federal de Santa Catarina, s.d.

AGUILAR, M. B. R.; ROSENTHAL, R.; REZENDE, D. B. Professora ou professor? Questão de gênero e socio-gênese das representações sociais sobre a docência do Timor-Leste. In: CONFERÊNCIA INTERNACIONAL SOBRE REPRESENTAÇÕES SOCIAIS, 13, Marseille, 2016. Anais. Marseille: Palais du Pharo, s.d.

BORTOLAI, M. M. S.; AGUILAR, M. B. R.; ROSENTHAL, R.; VOGEL, M. Representação social de professores do Ensino Fundamental sobre Sequência Didática. In: CONFERÊNCIA INTERNACIONAL SOBRE REPRESENTAÇÕES SOCIAIS, 13, Marseille, 2016. Anais. Marseille: Palais du Pharo, s.d.

ROSENTHAL, R.; MURAMATSU, M.; REZENDE, D. B. Ser mulher na Ciência: a questão de gênero nas Ciências da Natureza e na Matemática. In: ENCONTRO NACIONAL DE ENSINO DE QUÍMICA, 18, Florianópolis, 2016. Anais. Florianópolis: Universidade Federal de Santa Catarina, s.d.

AGUILAR, M. B. R.; BORTOLAI, M. M. S.; ROSENTHAL, R.; REZENDE, D. B. Professoras de Ciências da Natureza na educação timorense: questão de gênero na análise da sóciogênese. In: ENCONTRO NACIONAL DE ENSINO DE QUÍMICA, 18, Florianópolis, 2016. Anais. Florianópolis: Universidade Federal de Santa Catarina, s.d.

ROSENTHAL, R.; MURAMATSU, M.; REZENDE, D. B. Ser mulher na Ciência: um estudo sobre a questão de gênero nas Ciências da Natureza e na Matemática. In: ENCONTRO INTERNACIONAL DA REDE FEMINISTA NORTE E NORDESTE DE ESTUDOS E PESQUISAS SOBRE MULHER E RELAÇÕES DE GÊNERO, 19, São Cristóvão, 2016. Anais. São Cristóvão: Universidade Federal de Sergipe, 2016.

ROSENTHAL, R.; MURAMATSU, M.; REZENDE, D. B. A Ciência é feminina: um estudo sobre a questão de gênero nas Ciências da Natureza e na Matemática. In: ENCONTRO DO PROGRAMA DE PÓS-GRADUAÇÃO INTERUNIDADES EM ENSINO DE CIÊNCIAS DA USP, 11, São Paulo, 2016. Anais. São Paulo: Faculdade de Educação, Universidade de São Paulo, 2016. 


\section{Introdução}

Segundo dados da UNESCO (2015), apenas 33,1\% do total de graduados(as) nas áreas das Ciências da Natureza e Exatas ${ }^{1}$, no Brasil, são mulheres. Além disso, à medida que se avança na hierarquia da carreira, o número de mulheres decresce. Atualmente, no Brasil, as mulheres representam somente $35 \%$ de bolsistas de produtividade em pesquisa (PQ) do Conselho Nacional de Desenvolvimento Científico e Tecnológico (CNPq) nas áreas das Exatas (BRASIL, 2014), número que também diminui conforme se avança na carreira acadêmica.

Os estudos de gênero nas Ciências da Natureza e Exatas não são novos, mas algumas discussões são relativamente recentes. Embora as mulheres tenham sido excluídas da instrução ao longo da história, ainda assim, algumas das poucas que conseguiram estudar chegaram a voltar-se a áreas científicas, o que é bem pouco citado.

Umas poucas mulheres, entretanto, estudaram e lecionaram em
universidades a partir do século XIII - primeiramente na Itália. Elas com
frequência prosperavam em campos, como a física e a matemática,
considerados, hoje, especialmente resistentes às incursões femininas. O
exemplo mais excepcional foi o da física Laura Bassi, que, em 1732, tornou-
se a segunda mulher na Europa a receber um grau universitário (depois da
veneziana Elena Cornaro Piscopia, em 1678) e a primeira a ser agraciada
com uma cadeira na universidade (SCHIEBINGER, 2001, p. 61).

No final do século XVII, surge a primeira enciclopédia sobre a história das conquistas das mulheres nas Ciências da Natureza e, em 1894, faz-se a primeira conferência sobre a temática (SCHIEBINGER, 2001). Desde essa época até hoje, foram publicados diversos estudos sobre o tema, embora esses estudos sobre a temática tenham crescido substancialmente só a partir da década de 1970.

Quando se fala em gênero, assim como em sexualidade, raça, etnia e classe, está-se falando de diferenças e de desigualdades. Ao falarmos sobre gênero, a despeito das diferentes formas de conceituá-lo, o senso comum refere-se a classificações dicotômicas e hierárquicas entre masculino e feminino, mas também é importante entender como estão configuradas as relações de poder entre homens e mulheres. O termo gênero, segundo Joan Scott (1995, p. 7), "coloca a ênfase sobre todo um sistema de relações que pode incluir o sexo, mas que não é diretamente determinado pelo sexo nem determina diretamente a sexualidade". Ela explica que:

\footnotetext{
1 Nesta Dissertação, adota-se um critério epistemológico para a classificação dos campos do saber, que não se vincula estritamente à definição de áreas adotada pela CAPES e pelo CNPq. Ao longo do trabalho, essa área mais abrangente será designada como Ciências ou Ciências da Natureza e Exatas.
} 
[...] o gênero é igualmente utilizado para designar as relações sociais entre os sexos. O seu uso rejeita explicitamente as justificativas biológicas, como aquelas que encontram um denominador comum para várias formas de subordinação no fato de que as mulheres têm filhos e que os homens têm uma força muscular superior. O gênero se torna, aliás, uma maneira de indicar as 'construções sociais' - a criação inteiramente social das ideias sobre os papéis próprios aos homens e às mulheres. É uma maneira de se referir às origens exclusivamente sociais das identidades subjetivas dos homens e das mulheres (SCOTT, 1995, p. 7).

Segundo dados do censo do Diretório de Grupos de Pesquisa (DGP) do CNPq (2013), apesar de algumas áreas das Ciências da Natureza e Exatas terem aumento do número de mulheres ao longo dos últimos anos, carreiras como Engenharia, Matemática, Computação e Física são ocupadas em maior número pelos homens até hoje, enquanto cursos como Fonoaudiologia, Serviço Social e Pedagogia são escolhidos, predominantemente, por mulheres. Uma das construções sociais que está por trás desses números é a de que as mulheres teriam mais aptidão para carreiras que envolvem "cuidar do outro". E essa ideia é a mesma que pode impedir ou dificultar o percurso delas na carreira científica, já que existe a "obrigação social" de colocar o cuidado com a família à frente da carreira. O próprio site do CNPq (2013) justifica os dados do censo, usando essa mesma consideração.

Para as pesquisadoras Hildete Melo e Lígia Rodrigues, na publicação Pioneiras da Ciência do Brasil, a inclusão das mulheres nas profissões científicas tem se dado em ritmo mais lento do que em outras áreas e há uma tendência das ciências exatas - matemática, física, engenharias atraírem relativamente poucas mulheres. Isso se explica, de acordo com as pesquisadoras, provavelmente pelas dificuldades em conciliar a vida familiar e a afetiva com a grande dedicação exigida pela prática da ciência, sobretudo considerando-se as atuais exigências de "produtividade" e a enorme competição inerente à atividade (CNPq, 2013).

Essa justificativa está baseada na responsabilidade, que é atribuída essencialmente às mulheres, de conciliar a vida afetiva, familiar e doméstica com a carreira científica. Gerda Lerner $(1993)^{2}$ apud Londa Schiebinger (2001, p. 182) disse que: "A divisão sexual do trabalho que atribuiu às mulheres a responsabilidade principal pelos serviços domésticos e criação dos filhos liberou o homem dos incômodos detalhes das atividades diárias de sobrevivência, ao passo que sobrecarregou as mulheres de forma desproporcional".

A produtividade de uma mulher que conduza sua carreira científica pari passo com os afazeres domésticos é cobrada tanto quanto a de qualquer pessoa que se dedique à carreira em tempo integral e exclusivo. Nesse sentido, a comparação é desleal, o que faz muitas mulheres desistirem da carreira pela família.

À medida que as mulheres começaram a tomar seus lugares nas profissões, certos aspectos da vida profissional foram reformados. A esfera

2 Lerner, G. The Creation of Feminist Consciousness: From the Middle Ages to Eighteen-Seventy. New York: Oxford University Press, 1993. 
doméstica, entretanto, nunca foi submetida à ação afirmativa ou emendas legislativas que requerem a redistribuição do trabalho doméstico. As mulheres em relações heterossexuais geralmente permanecem - de modo relutante ou não - encarregadas da família e do lar. Em consequência, as mulheres que saem para trabalhar acrescentam uma profissão exigente ao que costumava ser considerado um trabalho de tempo integral. Ser cientista, esposa e mãe é uma carga em uma sociedade que espera que as mulheres, mais do que os homens, ponham a família à frente da carreira (SCHIEBINGER, 2001, p. 182).

De acordo com dados do IBGE (BRASIL, 2017), somando-se as horas dedicadas a atividades domésticas, a cuidados com a família e à ocupação fora do lar, as mulheres trabalham mais do que os homens, com uma carga horária média que ultrapassa 54 horas semanais, enquanto os homens trabalham, em média, 51,5 horas semanais.

Com o excesso da carga de trabalho em casa, a chance de a produtividade nas atividades fora do lar cair é alta, assim como cresce também a de desistência ou de interrupção da carreira. Um estudo da UNESCO (2015), mostra que as áreas Física, Química, Biologia, Engenharia e Tecnologia são as que possuem menos mulheres na pesquisa, ou seja, em nível avançado da carreira. Assim, se já há muito menos mulheres do que homens no ingresso e ao final da Graduação dos cursos de Ciências da Natureza e Exatas no Brasil, além de uma evasão grande delas durante o percurso acadêmico até chegar à pesquisa, o número de mulheres cientistas no topo da carreira pode se tornar extremamente subrepresentado em relação à porcentagem de mulheres na população.

Nesse contexto, são necessários estudos para investigar os motivos que levam tão poucas mulheres a se interessarem pelas Ciências da Natureza e Exatas, a permanecerem na carreira e a ascenderem nela.

Diversos trabalhos têm sido feitos com o intuito de chamar a atenção de mais mulheres para o ingresso nas áreas das Ciências da Natureza e Exatas. Uma das abordagens é o projeto denominado "Tem menina no circuito", aprovado no Programa Meninas e Jovens Fazendo Ciências Exatas, Engenharias e Computação ${ }^{3}$, que propõe a utilização de tecidos e papeis para a montagem de circuitos elétricos, a fim de atrair mais meninas para a Física. A partir de projetos e estudos como esse, ainda que sejam completamente válidos e necessários, abre-se a questão: Por que a interface com outras áreas, como neste caso em que a Física está-se unindo à Arte, torna as Ciências da Natureza e Exatas mais atraentes para as mulheres?

${ }^{3}$ Programa que tem por objetivo principal incentivar estudantes mulheres a ingressar nas carreiras de Ciências Exatas, Engenharias e Computação. Parceria do Ministério de Ciência, Tecnologia e Inovação - MCTI com o Conselho Nacional de Desenvolvimento Científico e Tecnológico - CNPq, a Secretaria de Políticas para as Mulheres da Presidência da República - SPM-PR e a Petróleo Brasileiro - Petrobras, chamada no 18 de 2013. Disponível em: <resultado.cnpq.br/3458553434931920>. Acesso em: 30 jun. 2017. 
O que está por trás de um dos motivos que pode tornar eficiente esse projeto é a construção da cultura que conhecemos hoje, que faz as mulheres e os homens serem atraídos inconsciente ou conscientemente para determinados interesses. A questão de grande parte das mulheres e dos homens gostarem mais de determinados campos que outros é explicada, dentre outros fatores, pela força dos estereótipos presentes em nossa sociedade.

A noção do que se entende por estereótipos aparece a partir das relações sociais. Diferentes contextos sociais podem conduzir à construção de diferentes estereótipos. Bardin (1977) define:

O estereótipo é "a ideia que temos de...", a imagem que surge espontaneamente, logo que se trate de... É a representação de um objeto (coisas, pessoas, ideias) [...], partilhada pelos membros de um grupo social [...]. Estrutura cognitiva e não inata (submetida à influência do meio cultural, da experiência pessoal, de instâncias e de influências privilegiadas como as comunicações de massa), o estereótipo, no entanto, mergulha as suas raízes no afetivo e no emocional, porque está ligado ao preconceito por ele racionalizado, justificado ou engendrado (BARDIN, 1977, p. 51).

Os estereótipos são tão poderosos que podem delimitar espaços entre as pessoas desde muito cedo, até mesmo antes do nascimento, já estabelecendo o que é "esperado" das meninas e dos meninos e, posteriormente, influenciando suas escolhas futuras. Essa espécie de normatividade naturalizada também permeia o que conhecemos como sexismo, que é a discriminação baseada no sexo, ou seja, utiliza-se da justificativa de as mulheres e os homens "nascerem assim" e, por isso, terem determinadas características que se tornam praticamente imutáveis, como "mulheres cuidam melhor de filhos", "mulheres cuidam melhor da casa", "homens são melhores líderes". O sexismo, definido pelas feministas do início da segunda fase ${ }^{4}$ do feminismo (1960 a 1980, aproximadamente), pode levar à naturalização das desigualdades de gênero, além de também poder decorrer dela e se justificar nessa naturalização das diferenças.

De alguns anos para cá, o tema gênero e Ciências da Natureza e Exatas vem ganhando espaço, há mais trabalhos na área, mais programas premiando projetos científicos que valorizem a diversidade de gênero e está mais fácil dialogar sobre o assunto. Mas ainda há muito a fazer. As Ciências da Natureza e Exatas não podem ser apenas masculinas e é necessário que mais mulheres se interessem pela carreira e permaneçam nela, crescendo, produzindo e contribuindo para a vida de todos - o que é um dos papeis importantes do campo, que não deveria prescindir precocemente de cerca de $50 \%$ das pessoas que se poderiam interessar pela área, as mulheres.

4 O feminismo, como movimento social de luta das mulheres, teve três grandes fases, também chamadas de ondas, divididas desde seu início, no século XIX, até hoje. Há teóricas que dizem que o momento atual que vivemos seria uma quarta onda. 


\section{Objetivos}

A presente pesquisa estruturou-se em torno da investigação acerca da baixa representatividade de mulheres nas Ciências da Natureza e Exatas. O objetivo geral deste trabalho foi o de desvelar possíveis fatores que levam à pouca permanência e ascensão delas no campo.

Sendo assim, foram estabelecidos alguns objetivos específicos:

- conhecer a história das mulheres na sociedade, na Educação e nas carreiras científicas;

- identificar os papeis sociais construídos em nossa cultura e analisar como eles influenciam nas escolhas profissionais das mulheres;

- investigar mecanismos desenvolvidos por mulheres cientistas para permanência e ascensão na carreira;

- refletir sobre possibilidades de caminhos para o incentivo de meninas a ingressarem na carreira e o de mulheres a permanecerem nela. 


\section{Referenciais teóricos}

\subsection{Sobre o feminismo e a história das mulheres}

O que marca a história das mulheres de forma diferente das outras é o fato de estar ligada diretamente a um movimento social: por um longo período, ela foi escrita a partir de convicções feministas (TILLY, 1994).

O feminismo é um movimento político e social que tem por base questionar as relações de poder na sociedade, no que se refere à condição das mulheres, buscando contribuir para o estabelecimento de uma situação mais justa e igualitária.

O feminismo é uma filosofia universal que considera a existência de uma
opressão específica a todas as mulheres. Essa opressão se manifesta tanto
a nível das estruturas como das superestruturas (ideologia, cultura e
política). Assume formas diversas conforme as classes e camadas sociais,
nos diferentes grupos étnicos e culturas (TELES, 2017, p. 22).

Para se compreender a importância do feminismo como movimento, e, mais que isso, dos estudos sobre as mulheres, é preciso investigar a situação da mulher no mundo e no Brasil ao longo de toda a história. Não há como falar de feminismo sem falar da História. Mas há tanto a falta de registros suficientes, quanto o desconhecimento sobre a participação das mulheres em diversos momentos históricos.

O Brasil colônia (1500-1822) era habitado por povos indígenas, que eram vistos pelos colonizadores como seres irracionais, o que explica porque os homens nativos eram úteis somente para o trabalho escravo e as mulheres, para trabalhos domésticos, esposas, concubinas ou mesmo corpos sexualizados (TELES, 2017).

Aliás, vale registrar que, em pleno ano de 1992 , num editorial do jornal
Folha de S. Paulo, de $11 / 2 / 1992$, intitulado "As meninas índias são
terríveis", o jornalista Gilberto Dimenstein denuncia as "curiosas
interpretações antropológicas" do coronel Francisco Abrão (comandante do
$5^{\circ}$. Batalhão Especial de Fronteiras do Exército), que afirma que seus
soldados são ameaçados de estupro pelas mulheres indígenas, quando
estas estão "no cio". E completa: "Eu tenho que segurar meus soldados,
porque eles não podem se aproveitar dessa deficiência das índias" (TELES,
2017, p. 28).

Durante o Brasil colônia, era pouco comum encontrar mulheres brancas. A maioria dos portugueses que veio para o Brasil era composta por homens; estes mantinham relações com as negras e índias brasileiras, o que aumentou a miscigenação, e muitos assassinavam suas esposas brancas por ciúmes, porque estavam longe e não as poderiam 
vigiar. A falta de mulheres brancas naquela época pode ter contribuído para a superioridade da mulher branca em relação à mulher negra ou indígena (TELES, 2017).

Além disso, M. Amélia Teles (2017) conta que o papel atribuído às mulheres brancas, naquela época, era o de serem esposas e mães, em meio a todas as atividades do lar (que também envolviam o direcionamento do trabalho das escravizadas). Algumas mulheres também faziam trabalhos manuais com tecidos, fios e rendas. As que não se casavam iam para o convento e a grande maioria encaixava-se nesses padrões. Só os homens estudavam e, nesse contexto, a Educação no Brasil era regida pela Igreja Católica, o que contribuía ainda mais para a construção de uma mulher ignorante e submissa.

Nesse contexto, a mão-de-obra de Portugal era composta por escravizados e escravizadas de origem africana. $O$ trabalho era tão árduo que a média de vida de mulheres e homens negros escravizados, que trabalhavam em plantações e minas, era estimada entre sete e dez anos. A mulher escravizada, além do trabalho igual ao dos homens, ainda era usada como objeto sexual. Muitas dessas mulheres escravizadas se recusavam a ter filhos, abortavam ou matavam seus filhos recém-nascidos para que não surgissem mais escravizados, lutando pela mudança da condição da escravatura (TELES, 2017).

A mulher negra, em sua condição de escrava, transferiu diferentes valores:
por um lado, reproduzindo a força de trabalho e, por outro, trabalhando nas
tarefas domésticas a serviço dos colonizadores, nas casas dos senhores na
cidade e no campo. Em ambos os casos, foi geradora de mais-valia nos
setores econômicos mais importantes: minas, fazendas e plantações. Enfim,
a divisão do trabalho por sexo se consolidou na Colônia, fortalecendo a
dupla opressão da mulher: de sexo e de classe (TELES, 2017, p. 31).

Até esse momento, o ensino era quase que em sua totalidade ocupado por homens. Às mulheres era permitida somente a instrução de primeiro grau e, ainda assim, voltada aos trabalhos do lar (costura, bordado, cozinha etc.) e não à leitura, geometria e cálculos, por exemplo, que eram estudos direcionados aos homens. Além disso, existiam menos escolas para meninas do que para meninos (LOURO, 1997).

Ao longo de todo o período colonial, muitas mulheres tiveram participações importantes, ainda que os registros sejam mínimos. Mais tarde, por volta do final do século XVIII, houve a Revolução Industrial, a consequente valorização do capital, e a então Independência do Brasil, quando o discurso sobre a importância da Educação torna-se cada vez mais forte, como aponta a autora Guacira Lopes Louro (1997).

Proclamada a Independência, parecia haver, ao menos como discurso oficial, a necessidade de construir uma imagem do país que afastasse seu caráter marcadamente colonial, atrasado, inculto e primitivo. E bem verdade que os mesmos homens e grupos sociais continuavam garantindo suas posições estratégicas nos jogos de poder da sociedade. No entanto, talvez fossem agora necessários outros dispositivos e técnicas que 
apresentassem as práticas sociais transformadas, ainda que muitas transformações fossem apenas aparentes. O discurso sobre a importância da educação na modernização do país era recorrente (LOURO, 1997, p. 443).

Nesse período, a Educação começa a ascender, pois, entre outros fatores, era necessário cada vez mais especializar os assalariados, mantendo o sistema capitalista em funcionamento. Assim, cursos de formação de professores, surgidos na Europa no século XVIII, fortalecem-se no Brasil nas denominadas Escolas Normais, que eram cursos de segundo grau.

À medida que cresce a demanda por professores generalistas, estabelece-se que a profissão de professor pode ser de interesse das mulheres, já que elas estavam associadas a todas as funções relacionadas ao lar e, portanto, ao cuidado e ensino de crianças. Assim, as mulheres começam a ser admitidas nas Escolas Normais.

Embora isso tenha sido uma grande conquista, outras implicações evidenciam-se a partir desse momento, já que as mulheres ocupavam os postos mais baixos da hierarquia do sistema educacional. Alguns estudos mostram como isso fortaleceu alguns estereótipos, como o da domesticidade feminina, e como isso contribuiu para a desvalorização do campo, uma vez feminizado, como aponta Cynthia Pereira de Sousa et al. (2015). Falaremos mais sobre isso adiante.

Educadas dentro e fora da escola para serem submissas, era-lhes natural que o saber emanasse do livro, do professor, do diretor, do topo da pirâmide acadêmica ou administrativa, e não de suas próprias cabeças (SOUSA et al., 2015, p. 66).

Apesar de o Ensino Superior existir no Brasil desde 1808, as mulheres ingressaram somente por volta de $1881^{5} \mathrm{e}$, em 1887 , formou-se a primeira mulher brasileira no curso de Medicina, Rita Lobato Velho Lopes ${ }^{6}$. As grandes transformações, fruto do capitalismo instaurado, começam no fim do século XIX: abolição da escravidão (o que não significou a libertação total dos negros e negras) e ampliação dos meios de transporte, das cidades e do comércio. Caminhando para a Proclamação da República, chega-se à época em que começa a haver um pouco mais de participação das mulheres. No entanto, essas mulheres ainda pertenciam majoritariamente à classe dominante, que buscava assegurar 0 direcionamento do movimento da melhor forma para si, apesar de negros e negras já estarem lutando pelos mesmos ideais há pelo menos três séculos (TELES, 2017).

No início do século $X X$, as mulheres da classe trabalhadora, que estavam em maior número em indústrias de tecelagem e de costura, dentre outras, juntamente com os

${ }^{5}$ Disponível em: <http://www.faperj.br/?id=2748.2.6>. Acesso em: 19 jan. 2018.

6 Disponível em: <http://www.cienciaecultura.ufba.br/agenciadenoticias/noticias/primeira-medica-saiuda-instituicao-em-1887>. Acesso em: 12 jul. 2017. 
homens, começam a entrar em sucessivas greves no Brasil pela regulamentação do trabalho.

Até meados de 1920, as manifestações pela redução da jornada trabalhista e igualdade salarial entre homens e mulheres continuavam e uniram-se às reivindicações pelo voto feminino no Brasil. Em 1928, o estado do Rio Grande do Norte permitiu o voto às mulheres; entretanto, naquele ano seus votos foram anulados. O direito ao voto foi conquistado somente após a década de 1930. Depois, as lutas concentraram-se na proteção à maternidade.

\subsection{Mulheres no Ensino Superior e a violência simbólica}

Após séculos de proibições em relação ao que era permitido às mulheres na Educação, na política e no mercado de trabalho, mesmo com a admissão e o reconhecimento delas em diferentes campos, a sociedade ainda direciona o que pode ser "aceito" segundo padrões culturais e sociais.

Hoje as mulheres já não são proibidas de ingressarem em cursos superiores, mas ainda há uma discriminação que as direciona a determinados papeis desde cedo. Esses papeis estão relacionados a funções ditas "naturais" das mulheres, presas a um passado em que elas só podiam dedicar-se ao lar e às famílias como se suas capacidades fossem restritas a tais afazeres, enquanto os homens cumpriam o papel da instrução e do trabalho remunerado.

Há, assim, um "modelo de mulher" construído por prescrições de funções derivadas da condição biológica (PERROT, 2005), que conduz as mulheres a essas carreiras que elas imaginam que sejam próximas de suas características pessoais e que facilitam a flexibilização da jornada de trabalho, para conciliação com a vida e os afazeres domésticos, que ainda são majoritamente exercidos pelas mulheres (IPEA, 2017).

Dessa forma, na medida em que as mulheres se direcionam majoritariamente a determinadas profissões e os homens a outras, há o conceito estudado por Rebeca Ávila (2009) chamado de "guetização" das carreiras.

A discriminação no campo educacional mudou de roupagem na medida em que não ocorre mais por meio do impedimento de acesso, mas transfere-se para o interior do próprio sistema de ensino no qual a discriminação passa a acontecer no processo de escolha das carreiras, provocando a "guetização" por sexo, o que leva à formação de guetos profissionais. Essa "guetização" refere-se às possíveis escolhas, feitas pelas mulheres, por carreiras consideradas "tipicamente femininas" (ÁVILA, 2009, p. 93). 
Michelle Perrot (2005) fala sobre essas características que a sociedade enxerga como "femininas" que são colocadas como se fossem "ingredientes" de supostas "profissões de mulher".

Qualificações reais fantasiadas como "qualidades" naturais e subsumidas a um atributo supremo, a feminilidade: tais são os ingredientes da "profissão de mulher", construção e produto da relação entre os sexos (PERROT, 2005, p. 253).

Além das imposições sobre a conjecturada naturalidade de algumas características femininas, há uma inferiorização delas, mantendo as mulheres que explicitam essa "vocação" em um lugar menor, o que caracteriza um tipo de violência, que, nesse caso, por não ser física e/ou explícita, é simbólica.

Em um dos trabalhos de Bourdieu (2017), essa noção da violência simbólica é apresentada como diferente da violência física. $\mathrm{O}$ autor enfatiza que a violência física contra a mulher não pode ser minimizada ou esquecida, mas a violência simbólica precisa ser reconhecida como violência tão potente quanto qualquer outra, uma vez que é um dos meios de manutenção do sistema de estruturas de dominação que age sobre as mulheres. Ele também diz que essas estruturas

São produto de um trabalho incessante (e, como o tal, histórico) de reprodução, para o qual contribuem agentes específicos (entre os quais os homens, com suas armas como a violência física e a violência simbólica) e instituições, famílias, Igreja, Escola, Estado (BOURDIEU, 2017, p. 56).

Bourdieu não foi o único autor a tratar de violência simbólica, mas o conceito fortalece-se em seu trabalho, uma vez que ele aplica a ideia ao mecanismo de dominação sobre aqueles que a sofrem e esclarece que falar de violência "não-física", ainda que não seja a forma brutal de violência, é violência e, por isso, é cunhada dessa forma. É um processo violento, ainda que oculto, ainda que velado, ainda que disfarçado.

A violência simbólica em relação às mulheres age de diferentes formas, como, por exemplo, desde cedo classificando ações, brincadeiras, comportamentos, roupas, habilidades e desejos das crianças como "de menino" e "de menina", o que naturalmente já delimita o espaço principalmente das meninas; e, mais tarde, desmotivando as meninas com base, no fundo, na mesma ideia, que se refere ao que é aceito pela sociedade.

$\mathrm{Na}$ década de 1970, as Escolas Normais, onde as mulheres foram inicialmente admitidas, foram substituídas pelos cursos técnicos de Magistério e, nos anos 1990, a legislação indicou que os cursos de formação de professores para 010 Ciclo do Ensino Fundamental passassem a ser de Ensino Superior em Faculdades de Educação ou Escolas Normais Superiores. Desde a admissão das mulheres nesses cursos, até hoje, a situação é praticamente a mesma: as mulheres são maioria nesses cursos de formação de 
professores, como Pedagogia e Licenciaturas, além de também maioria em campos como Enfermagem, Serviço Social, Psicologia e outros de Ciências Humanas.

Como falamos anteriormente, foi após a industrialização que houve um processo que gerou a demanda de cursos de formação de professores; as mulheres passaram a ser admitidas nesses cursos com a premissa de que eram profissões que se encaixavam perfeitamente nas características delas, que já estavam acostumadas a cuidar do lar e da família. Além disso, também havia um interesse do governo em reduzir custos nessa ampliação da oferta de ensino e, como a mulher era vista como "naturalmente" cuidadora ou professora, devido à uma vocação nata, era de se esperar, então, que ela nem cobrasse ou cobrasse muito menos do que um homem (RABELO; MARTINS, 2010). Essa correlação entre a vocação e a profissão de professor pode ser uma das razões para a desvalorização da área ainda hoje.

Quando se inaugurou em São Paulo a seção feminina da Escola Normal, segundo alguns historiadores, esta foi primeiramente destinada às jovens de poucos recursos e às órfãs sem dote, às quais eram interditos os sonhos de um bom casamento, dado que este se apoiava necessariamente em bases econômicas. Sendo difícil casar-se, precisavam essas moças, para não ser um peso para a sociedade, conseguir um meio de subsistência proporcionado por uma profissão digna, de acordo com o ideal feminino e que não atentasse contra os costumes herdados dos portugueses de aprisionar a mulher no lar e só valorizá-la como esposa e mãe. Portanto, ser professora representava um prolongamento das funções domésticas e instruir e educar crianças, sob o mascaramento da missão e da vocação inerentes às mulheres, significava uma maneira aceitável de sobrevivência, na qual a conotação negativa do trabalho remunerado feminino esvaía-se perante a nobreza do magistério (ALMEIDA, 1996, p. 747, apud RABELO; MARTINS, 2010, p. 6172).

Assim, a partir do momento em que a profissão de professor é feminizada, passa a ter baixo prestígio social. Sousa et al. (2015) aponta essa correlação entre o ingresso das mulheres e a desvalorização da carreira.

É como se a educação feminina, mais tarde contaminando a educação de forma geral, padecesse de mal estar estrutural em relação ao saber. Começando pela formação: sob a visão do alto da hierarquia acadêmica e administrativa, havia algo de suspeito, no sentido de ilegítimo, menor, ou menos ambicioso, na escolha de um curso cujo objetivo era o magistério. A suspeição se confirmava através de inúmeros indicadores: o fato, por exemplo, de que, nos cursos de formação de professores, os professores que formavam professores nas ciências ditas aplicadas não fossem eles próprios cientistas, mas pedagogos. E quando o eram, algo de estranho havia em lecionar numa escola dedicada a formar professores e mulheres; sempre era possível devolver-lhes a acusação que faziam às alunas: a de terem transformado em vocação a ausência de melhor escolha (SOUSA et al., 2015, p. 66).

${ }^{7}$ ALMEIDA, J. S. de. Mulheres na escola: Algumas reflexões sobre o magistério feminino. Cadernos de Pesquisa. São Paulo, n. 96, p. 71-78, fev., 1996. 
No ensino infantil, há muitas crianças que são ensinadas a chamar a professora de "tia", o que sugere proximidade com aquela que é responsável por cuidar de seus alunos como se fosse parte da família - uma "tia" -, alguém que se acredita que faz isso por amor e não por ofício. Esse tratamento evidencia a desvalorização da profissão de professora de Ensino Infantil e Fundamental.

Ensinar é profissão que envolve certa tarefa, certa militância, certa especificidade no seu cumprimento enquanto ser tia é viver uma relação de parentesco. Ser professora implica assumir uma profissão enquanto não se é tia por profissão. Pode-se ser tio ou tia geograficamente ou afetivamente distante dos sobrinhos, mas não se pode ser autenticamente professora, mesmo num trabalho a longa distância, "longe" dos alunos (FREIRE, 1994, p. 11).

Com o passar dos anos, os homens que ingressavam nas áreas da Educação tinham mais autoridade, chegando a cargos maiores como coordenações, direções, lideranças, ou mesmo se tornavam professores de Ensino Médio, Técnico e Profissional, enquanto as mulheres eram mantidas no Ensino Infantil e Fundamental - quadro que é mantido até hoje, no que se refere aos estágios iniciais das escolas.

Dados do censo do Instituto Nacional de Estudos e Pesquisas Educacionais Anísio Teixeira do Ministério da Educação (BRASIL, 2009) mostram que, no Brasil, as mulheres são maioria no Ensino Infantil e, à medida que se avança para o Ensino Médio e a Educação Profissional, elas ficam cada vez menos presentes (Figura 1). Outro estudo (BRASIL, 2012) mostra a relação entre o número de mulheres e homens ingressantes em determinados campos no Brasil (Tabela 1).

A UNESCO (2015) divulgou uma tabela que apresenta a porcentagem de mulheres Graduadas em todas as áreas de conhecimento, por país, em 2013 ou anos próximos. No Brasil (vide Tabela 2), só 33,1\% dos cientistas formados em áreas como Física, Química, Biologia, Matemática, Computação e Estatística são mulheres. Já as áreas da Saúde e bemestar têm $77,1 \%$ de mulheres.

Imaginemos a situação de uma criança que faz parte de uma família tradicional heterossexual, em que sua mãe é responsável por todas as tarefas do lar, além do trabalho que faz fora de casa. Durante seu crescimento, a concepção da criança é a de que todas as atividades familiares e domésticas são responsabilidades de uma mulher que, no caso, é sua mãe. Ao chegar na escola, depara-se apenas com professoras mulheres no Ensino Infantil e Fundamental.

A criança possivelmente está inserida, ainda, em uma cultura que privilegia bonecas como presentes para meninas e jogos mecânicos ou eletrônicos para os meninos. Assim, meninas são estimuladas, desde cedo, ao cuidado com o outro e à maternidade, brincando 
com bonecas, enquanto os meninos são incitados aos jogos eletrônicos ou de montagens, desenvolvendo raciocínio e lógica, habilidades diretamente relacionadas às áreas científicas.

À medida que aquela criança, agora adolescente, avança para o Ensino Médio, a quantidade de professoras mulheres vai diminuindo, sobretudo nas áreas das Ciências da Natureza e Exatas, como se infere dos dados (Figura 1 e Tabela 2). Os meios de comunicação em geral - mídia, filmes, livros, séries, aulas e outros materiais - quase não citam mulheres cientistas. Muitas vezes, quando as citam, são mulheres estereotipadas: pouco sociáveis e esquisitas. Isso sem falar nas várias que são omitidas da História da Ciência, por terem suas contribuições excluídas. Ou seja, além da baixa representatividade de mulheres nessas áreas, as poucas que existem são, frequentemente, menosprezadas. Como essa criança poderá entender as Ciências da Natureza e Exatas como um lugar de todos?

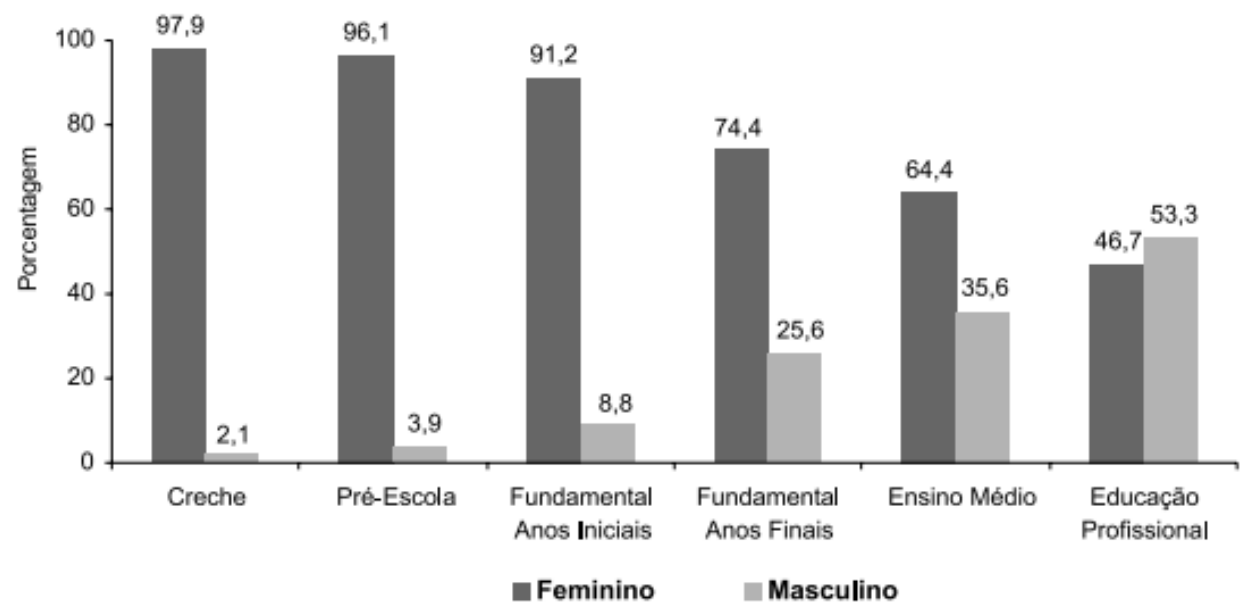

Figura 1: Professoras(es) da Educação Básica - Brasil (2012).

Tabela 1: Distribuição de matrículas em cursos de Graduação em função do gênero.

\begin{tabular}{l|l|l|l}
\hline $\begin{array}{l}\text { Cursos com } \\
\text { mais matrículas } \\
\text { do gênero } \\
\text { feminino }\end{array}$ & $\begin{array}{l}\text { Número } \\
\text { de } \\
\text { matrículas }\end{array}$ & $\begin{array}{l}\text { Cursos com mais } \\
\text { matrículas do gênero } \\
\text { masculino }\end{array}$ & $\begin{array}{l}\text { Número } \\
\text { de } \\
\text { matrículas }\end{array}$ \\
\hline Pedagogia & 556.283 & Engenharia Civil & 143.868 \\
\hline Enfermagem & 198.872 & Ciência da computação & 108.874 \\
\hline Serviço social & 157.242 & Engenharia de produção & 90.266 \\
\hline $\begin{array}{l}\text { Gestão de } \\
\text { pessoas/ } \\
\begin{array}{l}\text { Recursos } \\
\text { humanos }\end{array}\end{array}$ & 135.067 & Engenharia mecânica & 75.938 \\
\hline Psicologia & 131.786 & $\begin{array}{l}\text { Formação de professor } \\
\text { de educação física }\end{array}$ & 71.293 \\
\hline Fisioterapia & 81.982 & Engenharia elétrica & 67.303 \\
\hline Farmácia & 72.342 & Gestão logística & 61.054 \\
\hline
\end{tabular}

Fonte: Brasil (2012). 
Tabela 2: Porcentagem de mulheres Graduadas em quatro campos de conhecimento, em 2012.

\begin{tabular}{c|c|c|c|c}
\cline { 2 - 5 } & Ciências & Engenharia & Agricultura & $\begin{array}{l}\text { Saúde e } \\
\text { bem-estar }\end{array}$ \\
\hline Brasil & 33,1 & 29,5 & 42,3 & 77,1 \\
\hline
\end{tabular}

Fonte: UNESCO (2015).

\subsection{A condição feminina por Beauvoir}

Simone de Beauvoir foi uma escritora, filósofa existencialista, militante feminista e teórica social francesa, que escreveu diversos romances, biografias e outros materiais sobre política, filosofia e questões sociais. Beauvoir ficou mais conhecida depois de seu livro "O segundo sexo", publicado em 1949.

A autora já falava em seus trabalhos sobre a construção que objetifica as mulheres e as nega como sujeitos. No contexto dessa concepção, a autora trabalha o conceito da condição e da situação da mulher na sociedade: não é por ela ter nascido inferior que the faltam oportunidades, mas por ela ter sido colocada em tal lugar. Além disso, esse lugar inferior das mulheres, pré-definido pela sociedade, fixa-as em uma suposta essência (BEAUVOIR, 2009).

Beauvoir (2009) refuta essa ideia e explica que há características, entendidas como essencialmente femininas, que são usadas para justificar determinados processos sociais. A autora identifica esse lugar que é imposto à mulher até mesmo antes de ela tentar lutar para sair dele e explica essa dificuldade de transcendência, conceito que ela também trabalha em relação à liberdade que é tirada das mulheres.

Todo sujeito coloca-se concretamente através de projetos como uma transcedência; só alcança sua liberdade pela sua constante superação em vista de outras liberdades; não há outra justificação da existência presente senão sua expansão para um futuro indefinidamente aberto. Cada vez que a transcedência cai na imanência, há degradação da existência em "em si", da liberdade em facticidade; essa queda é uma falha moral, se consentida pelo sujeito. Se lhe é infligida, assume o aspecto da frustração ou opressão. Em ambos os casos, é um mal absoluto. Todo indivíduo que se preocupa em justificar sua existência sente-a como uma necessidade indefinida de se transcender. Ora, o que define de maneira singular a situação da mulher é que, sendo, como todo ser humano, uma liberdade autônoma, descobre-se e escolhe-se num mundo em que os homens lhe impõem a condição do Outro. Pretende-se torná-la objeto, voltá-la à imanência, porquanto sua transcendência será perpetuamente transcendida por outra consciência essencial e soberana. O drama da mulher é esse conflito entre a reivindicação fundamental de todo sujeito que se põe sempre como 
essencial e as exigências de uma situação que a constitui como inessencial (BEAUVOIR, 2009, p. 30).

A situação da não transcendência das mulheres contribui, portanto, para a deterioração de sua imagem e consequente confinamento delas a determinados lugares. Djamila Ribeiro (2012), em trabalho de pesquisa sobre as obras de Simone de Beauvoir, explica como isso acaba recaindo na suposta essencialidade feminina.

A opressão das mulheres é ainda mais poderosa porque é mascarada por trás da natureza; a crença de que o destino da mulher é ser passiva. E quando elas nisso acreditam e isso internalizam, não veem o mundo como seu e se deixam ficar presas em sua situação imediata. Como a transcendência é negada, é negado também acesso aos outros valores humanos (RIBEIRO, 2012, p. 490).

Ribeiro (2013, p. 506) chama essa opressão da mulher, por essa conjecturada natureza feminina, de sexismo biológico. O conceito é uma referência ao termo racismo biológico, que marcou "a relação de superioridade e inferioridade entre colonizadores e conquistados, mais precisamente na América, que legitimou as relações de dominação europeia, ao atribuir aos negros uma 'inferioridade natural' devido à cor e tamanho do cérebro". Assim, a utilização do termo também é uma referência à ideia de inferioridade natural da mulher. A autora explica que, apesar de haver muitas diferenças entre as opressões de gênero e raciais, o intuito da utilização do termo é o de denominar a opressão que as mulheres sofrem enquanto se naturalizam algumas características que as colocam em posição inferior.

Ao tratar da inferioridade da mulher nos dias atuais, muitos contestam, argumentando com ideias, tais como as de que, hoje: já há igualdade, as mulheres já estão no mercado de trabalho, votam, em muitas áreas já se conquistaram salários iguais para homens e mulheres e várias são líderes em seus grupos. É inegável tudo que já foi alcançado até hoje, há de se ressaltar: com muita luta. No entanto, ainda existem diversos tipos de dominação sobre as mulheres. Inclusive, há questões raciais e étnicas que praticamente não mudaram em séculos. Existem alguns tipos de opressão que ainda estão presentes e são pouco reconhecíveis como violências.

Simone de Beauvoir (2009) já falava, na década de 1940, sobre o conceito de igualdade abstrata versus igualdade concreta, problematizando justamente isso: as mulheres foram conquistando seus espaços, mas onde estão essas mulheres? Que cargos elas estão exercendo? Como elas estão sendo tratadas? Em que áreas elas estão trabalhando? Há reconhecimento delas em seus trabalhos? Elas são visíveis em suas histórias? Como são seus espaços na família e em casa? Que funções estão concentradas 
nas mãos delas? Quase todas essas questões podem ser respondidas somente pelo que foi exposto até agora, mas será aprofundado adiante.

O homem pode, pois, persuadir-se de que não existe mais hierarquia social entre os sexos e de que, grosso modo, através das diferenças, a mulher é sua igual. Como observa, entretanto, algumas inferioridades - das quais a mais importante é a incapacidade profissional -, ele as atribui à natureza. Quando tem para com a mulher uma atitude de colaboração e benevolência, ele tematiza o princípio da igualdade abstrata; e a desigualdade concreta que verifica, ele não a expõe. Mas, logo que entra em conflito com a mulher, a situação se inverte: ele tematiza a desigualdade concreta e dela tira autoridade para negar a igualdade abstrata. Assim é que muitos homens afirmam quase com boa-fé que as mulheres são iguais aos homens e nada têm a reivindicar e, ao mesmo tempo, que as mulheres nunca poderão ser iguais aos homens e que suas reivindicações são vãs (BEAUVOIR, 2009, p. 27).

No livro "As belas imagens", escrito por Simone de Beauvoir (1966), a autora fala sobre a imagem que construímos em nossas relações sociais, sobretudo as imagens que as mulheres acabam também elaborando de si, contaminadas pelos padrões androcêntricos construídos na sociedade. A personagem principal, Laurence, passa por diversas crises em seus relacionamentos como esposa, mãe, filha e amiga e, em diversas passagens, sente-se mal em expor sua opinião em discussões entre várias pessoas, principalmente com homens: ela sempre "falava bobagem", tanto na visão dela, quanto na visão dos presentes. Além disso, recorrentemente ela se compara a eles, tentando entender suas diferenças, questionando seus papeis sociais, quase sempre enxergando muitos defeitos em si, em meio a poucas qualidades.

A "sensibilidade exagerada" de Laurence é sempre questionada por seu marido Jean-Charles e, quando a filha do casal manifesta essa mesma característica, isso é ainda mais rechaçado por ele. Beauvoir (1966), pouco a pouco, mostra como as características que são essencialmente relacionadas à personalidade feminina são construídas na cabeça das pessoas e, inclusive, das mulheres, com imagem negativa.

Além disso, ao longo do livro, muitas discussões entre os homens mostram que eles até podem enxergar as mulheres como potentes e capazes, tratá-las de forma aparentemente igual e tratar a questão das mulheres na sociedade com importância, mas não deixam de inferiorizá-las, o que retoma o conceito de igualdade abstrata versus concreta trabalhado por Beauvoir em outras obras.

- O que penso de minhas colegas, cara senhora? - diz ele a Gisele. - O melhor possível, muitas são mulheres encantadoras e muitas têm talento (em geral, não são as mesmas). Mas uma coisa é certa: nunca nenhuma delas será capaz de discursar num tribunal. Não têm nem as cordas vocais, nem a autoridade, nem - vou surpreendê-los - o senso teatral necessário.

- Há mulheres que fazem sucesso em profissões que a priori lhes pareceriam proibidas - diz Jean-Charles. 
- A mais esperta, a mais eloquente, diante de um júri, eu a faria passar por idiota - diz Thirion.

- Vocês, talvez, vão ter surpresas - diz Jean-Charles. - Mas eu, eu acho que o futuro é das mulheres.

- Talvez, mas sob a condição de que elas não imitem os homens - diz Thirion.

(BEAUVOIR, 1966, p. 77)

Outra questão abordada nessa obra de Simone de Beauvoir (1966) é a de sempre se atribuir um peso negativo aos diferentes comportamentos das mulheres: quando Laurence era sensível demais, isso era um problema; quando seguia sua razão e tomava decisões mais práticas, era seca e sem coração, o que também era criticado: "Laurence está atônita. Uma vez, quando ela demonstrou sensibilidade exagerada, Dominique e depois JeanCharles trataram de sufocá-la completamente. Hoje, Mona critica sua indiferença e Lucien a acusa de não ter coração" (Beauvoir, 1966, p. 103). Quando Laurence emociona-se com a história de uma mulher torturada até a morte, publicada em um jornal, Jean-Charles a tranquiliza, mas algum tempo depois, quando a filha dos dois demonstra também sofrer com histórias que ela assistia na televisão, o marido critica a esposa, acusa-a de influenciar a filha com essas características, ou seja, a imagem da mulher sensível volta a incomodá-lo: "é você que a deixa biruta, com esses teus escrúpulos, tua sensibilidade exagerada" (Beauvoir, 1966, p. 103).

Laurence sente que empalideceu: como se ele a tivesse esbofeteado. Ela tremia, estava fora de si, quando lera a história daquela mulher torturada até a morte. Jean-Charles a abraçara, ela se abandonara confiante em seus braços, e ele dizia: "É horrível", ela pensou que ele também estivesse emocionado. Por causa dele, ela se acalmara, fazendo um esforço para afastar essa lembrança, e havia conseguido. Enfim era por causa dele que ela, desde então, evitara ler os jornais. Na realidade, ele pouco se importara com o caso, dizia "É horrível" só para acalmá-la: e agora atirava-Ihe o incidente na cara, com uma espécie de maldade. Que traição! Tão seguro de si e de seus direitos neste mundo. Furioso se abalamos a imagem que ele tem de nós, a menina e a mãe exemplares, sem ligar a mínima para o que somos realmente (BEAUVOIR, 1966, p. 102).

Simone de Beauvoir era realmente uma mulher com ideias à frente de sua época, mas o que mais impressiona é como as questões que ela já levantava há cerca de 80 anos atrás praticamente não mudaram em sua essência. Como Ribeiro (2012, p. 491) aponta, “a opressão apenas muda de forma e seus mecanismos foram modernizados. Estes nada mais são que opressões antigas ora disfarçadas". 


\subsection{0 sexismo científico}

Recentemente, em agosto de 2017, uma carta escrita por um funcionário de uma das maiores empresas de tecnologia do mundo ${ }^{8}$ foi divulgada na internet. A carta, que era uma comunicação interna entre os funcionários da empresa, afirmava que as mulheres não estavam em cargos altos e em áreas da Tecnologia por diferenças biológicas ${ }^{9}$. Entre outros argumentos, o autor diz que as diferenças de interesses de homens e mulheres em determinadas carreiras estão relacionadas a diferenças de natureza dos sexos. Em 2015, Tim Hunt, prêmio Nobel de Medicina e Fisiologia, disse que as mulheres atrapalham a pesquisa científica, de maneira que três coisas acontecem quando elas estão no laboratório: "você se apaixona por elas, elas se apaixonam por você e, quando você as critica, elas choram". Em 2005, o então presidente da Universidade de Harvard, Lawrence Summers, afirmou em uma conferência que as mulheres seriam menos aptas para as Ciências e Matemáticas por questões genéticas ${ }^{10}$. Em todos os casos expostos, a discussão é a mesma: supostas características biológicas que as inferiorizam pelo "natural", isso é, há um argumento de que a natureza das mulheres é tal que as torna inaptas para determinadas áreas.

A teoria evolucionista de Darwin ${ }^{11}$ (1871, apud DAUDER; SEDEÑO, 2017) já falava de seres superiores e inferiores em função de uma seleção sexual, na qual os machos, de maneira geral, lutariam pelas fêmeas, o que conduz a essa ideia do macho como ser superior.

Aceita-se, geralmente, que as mulheres estão mais fortemente marcadas do que os homens com os poderes da intuição, percepção rápida e, talvez, da imitação; mas pelo menos algumas dessas faculdades são características das raças inferiores e, portanto, de um estado passado e inferior de civilização (DARWIN, 1871, p. 725 apud DAUDER; SEDEÑO, 2017, p. 26, tradução nossa $\left.{ }^{12}\right)$.

\footnotetext{
${ }^{8}$ A empresa é a Google. Sobre a empresa: <https://pt.wikipedia.org/wiki/Google>. Acesso em: 02 set. 2017.

${ }^{9}$ Disponível em: <http://www.bbc.com/portuguese/geral-40848157>. Acesso em: 02 set. 2017.

${ }^{10}$ Disponível em:

$<$ http://www.bbc.com/portuguese/noticias/story/2005/01/050118_harvardcl.shtml>. Acesso em: 02 set. 2017.

11 DARWIN, C. The Descent of Man, and Selection in Relation to Sex. John Murray, Londres, 1871.

12 "Se admite por lo general que en las mujeres están más fuertemente marcados que en los hombres los poderes de intuición, percepción rápida y quizás de imitación; pero al menos alguna de estas facultades son características de las razas inferiores $y$, por tanto, de un estado pasado e inferior de civilización" (DARWIN, 1871, p. 725 apud DAUDER; SEDEÑO, 2017, p. 26).
} 
S. García Dauder e Eulalia P. Sedeño (2017) chamam a atenção para além do sexismo de Darwin, também seu racismo, uma vez que concebia raças dispostas hierarquicamente desde as primitivas às "perfeitas", como as europeias civilizadas, por exemplo. Dentro de cada raça, a mulher sempre estaria em lugar inferior ao macho da mesma raça, mas, uma vez as raças dispostas, também em superioridade/inferioridade, as mulheres europeias, brancas e de classes altas seriam mais evoluídas do que negros africanos.

Darwin deu voz às teorias aristotélicas em relação à inferioridade das mulheres como "homens imperfeitos", trabalhando a ideia de que as mulheres gastam mais suas energias do que os homens alimentando o feto, o que dificultaria a variabilidade genética feminina. Dessa forma, diversas características são associadas às mulheres de forma universal, como pertencentes à natureza de todas elas, além de serem relacionadas a estados menos evoluídos, imperfeitos e inferiores.

Popularmente e em pesquisas científicas, há muitas discussões sobre características de ordem cognitiva ou cerebral que determinem capacidades diferentes em homens e mulheres. Diversos estudos neurocientíficos e fisiológicos têm descartado que haja diferenças significativas entre cérebros de homens e mulheres e que possam influenciar em determinadas características e comportamentos.

Uma das maiores pesquisas sobre o tema (JOEL et al., 2015), realizada por um grupo de cientistas de Israel, Suíça e Alemanha, analisou 1.400 cérebros diferentes de homens e mulheres, comparando-os em relação a diversas propriedades. As amostras eram de voluntários e voluntárias de projetos científicos e foram estudadas a partir de uma técnica que utilizou imagens cerebrais e analisou as diferentes estruturas das áreas do cérebro.

O trabalho mostrou que o cérebro é um "mosaico de características" que não se distingue em categorias femininas e masculinas. Pelo contrário, há maioria de características comuns a homens e mulheres. Daphna Joel et al. (2015) ressaltaram que algumas podem ser mais comuns em mulheres, outras podem ser mais comuns em homens e outras podem ser comuns a ambos os grupos. O que é interessante observar é que os dados revelaram ampla sobreposição entre cérebros de mulheres e homens em traços de personalidade, atitudes, interesses e comportamentos, o que mostra que não há nada que seja "naturalmente" feminino ou masculino.

Em trabalho anterior ${ }^{13}$, a mesma autora já havia pesquisado diferenças cerebrais entre diferentes indivíduos e havia sugerido que o cérebro, se tivesse que ser classificado de

13 Disponível em: <https://www.ncbi.nlm.nih.gov/pmc/articles/PMC3176412>. Acesso em: 03 set. 2017. 
acordo com sexos distintos, estaria mais para um orgão intersexual, uma vez que não possui uma única estrutura relacionada ao masculino ou feminino. Joel (2011) afirmou que não há cérebro "masculino" e "feminino", mas uma forma altamente variável, que independe do sexo. Essa variabilidade é criada pela interação de genes, hormônios e ambiente, tanto no útero, como ao longo da vida.

Ceci, Williams e Barnett (2009) fizeram uma revisão bibliográfica de mais de 400 artigos publicados, capítulos de livros e outros materiais, a fim de analisar os fatores conexos à subrepresentação das mulheres em campos como as Ciências da Natureza e Exatas, no que se refere a habilidades e características delas que se relacionem a essas áreas. Em todo o trabalho, a pesquisa dividiu-se entre estudos que consideram os fatores biológicos determinantes nas habilidades e comportamentos de homens e mulheres e outros que consideram os fatores sócio-culturais mais influentes e conclusivos para essas características desses indivíduos.

Neste trabalho, discutem-se habilidades como visão e rotação espacial e facilidade para cálculos e problemas matemáticos, características, em geral, de pessoas que têm facilidade e interesse por carreiras científicas. Essas capacidades são relacionadas, em muitos desses trabalhos, a níveis hormonais de testosterona, hormônio que determina as características sexuais masculinas. As autoras dizem que praticamente todos os trabalhos que estudam a relação entre níveis de testosterona e habilidades visuo-espaciais são inconclusivos. E ainda acrescentam:

Apesar de alguns estudos identificarem efeitos da testosterona na perfomance espacial, estes resultados não podem ser imediatamente generalizados [...]. Níveis muito altos de testosterona frequentemente são associados com menores, ao invés de maiores, desempenhos espaciais [...] (CECl; WILLIAMS; BARNETT, 2009, p. 223, tradução nossa ${ }^{14}$ ).

O resultado desses estudos sugere que a associação entre níveis de testosterona e sucesso nas carreiras científicas não é conclusiva como dado científico, permitindo inclusive que se infira o contrário, em muitos trabalhos. Outro exemplo dado pelas pesquisadoras é o de um estudo realizado com taxistas de Londres. A pesquisa mostrou que todos os indivíduos desse estudo têm o hipocampo posterior maior, o que significa maior habilidade com memorização que, no caso deles, é desenvolvida pela utilização de mapas ou mesmo da memória visual de ruas e caminhos. Esse estudo apontou o contexto sócio-cultural como determinante nesses casos, uma vez que não haveria desenvolvimento e melhora da memória, se não fosse o trabalho e o contexto dessas pessoas.

14 "Further, despite some studies finding effects of testosterone on spatial performance, such findings cannot be readily generalized [...]. As noted, very high testosterone is often associated with reduced spatial scores, not enhanced ones [...]' (CECl; WILLIAMS; BARNETT, 2009, p. 223). 
Assim, as pesquisadoras afirmam que os fatores biológicos apontados em todos os mais de 400 trabalhos revisados em seu artigo são menos relevantes do que os aspectos sócio-culturais, de forma que: 1) habilidades como rotação e visão espaciais primeiramente não determinariam necessariamente o interesse das mulheres em carreiras científicas; 2) não há uma relação direta entre o sexo ou a produção hormonal relacionada a ele e determinadas características; 3 ) caso haja mulheres com dificuldade de visão espacial e cálculos, o contexto sócio-cultural pode contribuir para que isso não seja um fator decisivo nessa escolha delas.

Em um estudo recente (PARREIRAS-E-SILVA et al., 2017), que envolveu genética, farmacologia e observações comportamentais, administraram-se a camundongos, por via intranasal, duas diferentes formas do neurotransmissor oxitocina, anteriormente identificadas em macacos das Américas, em que há variação na posição relativa dos nove aminoácidos que constituem esse nonapeptídeo. Ele atua como hormônio e está relacionado às contrações uterinas, ao vínculo materno e ao prazer.

Embora, até então, o modelo era o de que a oxitocina tinha papel mais central em fêmeas, os resultados desse trabalho evidenciaram uma associação entre as duas variantes da oxitocina, que teriam papel funcional e evolucionário relevantes, em comportamentos de machos, incluindo cuidados paternos e monogamia (PARREIRAS-E-SILVA et al., 2017).

Pode-se inferir do estudo que as perspectivas científicas biologizantes acerca do papel "natural" da mulher no cuidado com a prole não se sustentam pois, segundo a pesquisa, espécies que expressam essas formas variantes do hormônio oxitocina como parte de um processo evolucionário têm uma participação importante dos machos nos cuidados com os filhotes. Em outras palavras, a oxitocina não serve apenas para a mãe lactar, para a contração uterina e para o vínculo amoroso entre mãe e prole, influi também no macho e modula comportamentos parentais nele (PARREIRAS-E-SILVA et al., 2017).

\subsection{Definições de gênero}

As definições de gênero começam a ser utilizadas pelas feministas americanas, no intuito de se referir, ao utilizar o termo, às relações inteiramente sociais entre os sexos, ou seja, rejeitando todo o tipo de justificativa biológica que utilize os termos "sexo" ou "diferença sexual" (SCOTT, 1995). Além disso, Scott (1995) mostra que estudos de gênero, que tratam da desigualdade entre os gêneros em determinados campos, não só colocam em pauta novas discussões, mas revisam trabalhos e histórias anteriores, por isso são tão importantes. 
A autora explica que os estudos que envolvem relações de gênero são dificultados por não terem força suficiente para mudanças de paradigmas históricos, já que o termo, nesse uso descritivo, evidencia uma série de relações sociais, mas não nos explica como resolvêlas. Ela complementa a ideia, apresentando as proposições teóricas de historiadoras feministas, que ela dividiu em três pilares: o primeiro, que explica as origens do patriarcado ${ }^{15}$; o segundo, que se apoia em teorias marxistas; e, o terceiro, que se inspira em teorias psicanalíticas, explicando a produção e reprodução da identidade de gênero do sujeito. A pesquisadora critica as concepções e aponta, nas três vertentes, a importância de se abordar a questão de gênero como uma categoria de análise que, segundo ela, só começou a ser preocupação teórica no final do século XX.

No mesmo trabalho (1995, p. 21), ela define gênero em duas partes, como "um elemento constitutivo de relações sociais baseado nas diferenças percebidas entre os sexos", e como "uma forma primeira de significar as relações de poder". Essa relação entre gênero, sexo e as relações de poder existentes também são objeto de reflexão de outros estudos nesse campo.

Nicholson (2000) inicia seu trabalho tratando da definição de gênero com raízes na distinção entre os termos gênero e sexo, no sentido de o primeiro tratar do que é socialmente construído e, o segundo, do que é biologicamente dado. Entretanto, ela complementa a definição de gênero, pensando no termo como referência à personalidade e ao comportamento e não aos corpos biológicos.

As relações entre sexo e gênero, na época da segunda fase do feminismo, eram feitas de forma que o sexo poderia justificar diferenças culturais construídas entre homens e mulheres, e o gênero, com sua maior abrangência, complementaria a ideia, sem substituí-lo, mostrando que nem sempre essas diferenças estavam baseadas única e exclusivamente no corpo: são conjuntos de relações sociais, históricas e culturais que compõem essa estrutura.

15 O "patriarcado" ou a "sociedade patriarcal" são conceitos utilizados em trabalhos sobre questões de gênero, com intuito de se referir à dominação masculina presente na sociedade em diversos campos. O termo tem origem na Antiguidade, é reapropriado na concepção socialista de Karl Marx e começou a ser usado pelos movimentos feministas dos anos 1970 que, baseados nos pressupostos de Friedrich Engels sobre o patriarcado, identificavam nele uma parte fundamental do sistema a ser combatido principalmente pelas mulheres. No entanto, há uma discussão entre linhas diferentes de estudos feministas sobre a utilização do termo. A relação de dominação dos homens em relação às mulheres hierarquiza, segundo o modelo marxista, trabalho e reprodução. Dessa forma, o modelo seria heterossexista, pois estaria pressupondo apenas um modelo de família, o heterossexual, no qual o papel reprodutivo e, por isso, inferior, é das mulheres. A crítica do uso do termo vem da concepção de que esse não seria o único sistema de dominação e relações de poder, pois neste modelo, as questões biológicas estão intrínsecas ao conceito, naturalizando e universalizando todas as mulheres, desconsiderando classes, raças, momentos históricos e diferentes mulheres que possam existir. O conceito remete à ideia de que essas relações são "naturais" e não leva em conta todo o processo complexo social, cultural e histórico envolvido e, além disso, tornando o problema ainda mais "imutável". 
Nicholson (2000) propõe, então, que o sexo, conceito variável, seria subsumido ao gênero, que é também variável. Essa ideia é ilustrada por ela em uma crítica que utiliza a analogia da identidade de cada indivíduo com um porta-casacos (acessório comum em países frios), que teria diferentes culturas "colocadas" nele, de diferentes tamanhos e formas, como os casacos. É como imaginar que a sociedade entenda o porta-casacos da mesma maneira em qualquer lugar do mundo, não importanto os casacos que estejam nele: analogamente, o "ser mulher" ou o "ser homem" entendido de forma independente do cenário cultural e social.

Quando se pensa o corpo como um "cabide" no qual são "jogados" certos aspectos de personalidade e comportamento, pode-se pensar no relacionamento entre os dados do "cabide" e aquilo que nele é jogado como mais fraco do que determinista, porém mais forte do que acidental. Não se é obrigado a jogar sobretudos e cachecóis num porta-casacos; pode-se, por exemplo, jogar suéteres e até diferentes tipos de objetos, basta mudar suficientemente a natureza material do cabide. Mas se sempre vemos um porta-casacos cheio de sobretudos e cachecóis, não exigimos muita explicação, afinal trata-se de um porta-casacos (NICHOLSON, 2000, p. 4).

Nicholson (2000) chama essa relação entre corpo, comportamento e personalidade de "fundacionalismo biológico", conceito que ela relaciona criticamente ao de determinismo biológico em seu trabalho, apontando a possibilidade de coexistência entre as questões biológicas e as questões de comportamento e personalidade, todas variáveis sociais, o que, portanto, leva à possibilidade de mudança em construções impostas por supostas naturezas.

A ideia do corpo como um porta-casacos, segundo a autora, é um dos obstáculos à compreensão do que é ser mulher, ou do que é entendido por feminino e masculino e suas relações sociais, já que frequentemente são feitas generalizações, ou seja, o sexo como um dado fixo e universal. A ideia de Nicholson (2000) relaciona-se com a crítica de Scott (1995), mencionada anteriormente, no que se refere ao sexo, portanto, não como um dado, mas como um conceito variável que envolve diversas relações para sua compreensão.

A autora Nicholson (2000) salienta que se deve pensar sobre o que se entende pelo corpo dentro de cada sociedade, considerando as semelhanças e as diferenças, abandonando estereótipos culturais e comportamentais. Por isso o corpo também é definido como uma variável.

O que acontece é que diferenças no sentido e na importância atribuídos ao corpo de fato existem. Esses tipos de diferenças, por sua vez, afetam o sentido da distinção masculino/feminino. A consequência é que nunca temos um único conjunto de critérios constitutivos da "identidade sexual" a partir do qual se possa inferir alguma coisa sobre as alegrias e as opressões inerentes ao "ser mulher" (NICHOLSON, 2000, p. 7). 
Nesse contexto, também é necessário relacionar gênero com as questões de classe, raça, com as diferentes sociedades, culturas e com o momento histórico a que estamos nos referindo. Scott (1995) diz que trabalhos voltados às categorias classe, raça e gênero assinalam

em primeiro lugar, o envolvimento do/a pesquisador/a com uma história que incluía as narrativas dos/as oprimidos/as e uma análise do sentido e da natureza de sua opressão e, em segundo lugar, uma compreensão de que as desigualdades de poder estão organizadas ao longo de, no mínimo, três eixos (SCOTT, 1995, p.73).

Isso significa, entre outros fatores, que, além de falar a respeito do menor número de mulheres em determinados campos, de quantas mulheres ganham menos em cargos idênticos aos dos homens, de quantas estão em cargos menores com qualificações iguais ou muitas vezes até melhores do que as dos homens, de quantas sofrem violências verbal, física, doméstica, moral, sexual, trabalhista, familiar, conjugal, de quantas têm seus estudos interrompidos, seus trabalhos desvalorizados só pelo fato de serem mulheres, entre outros, é essencial, também, pensar na repetição da construção dessas desigualdades, isto é, em fatores sociais e culturais que possam estar relacionados a isso e como se dá essa relação de poder perpetuada por séculos.

Se tratarmos a oposição entre homem e mulher como problemática e não como conhecida, como algo que é contextualmente definido, repetidamente construído, então devemos constantemente perguntar não apenas o que está em jogo em proclamações ou debates que invocam o gênero para explicar ou justificar suas posições, mas também como compreensões implícitas de gênero estão sendo invocadas ou reinscritas (SCOTT, 1995, p. 93).

Raewyn Connell (2015) em seu livro "Gênero: uma perspectiva global" faz uma comparação entre essas diferenças de gênero dentro de contextos diferentes, citando o trabalho de Moodie (1994) ${ }^{16}$ sobre o que é "ser homem nas minas" na África do Sul no final do século XIX. No caso, as minas de ouro passam a ser exploradas por colonos holandeses e britânicos, o que fazia, portanto, com que elas fossem grandes empresas industriais controladas por capital europeu. As práticas de gênero nas relações, segundo a autora, eram totalmente diferentes neste caso, se comparadas às de casais convencionais europeus, em que os homens têm o papel de provedores e as mulheres, o de reprodução e "dona de casa". Os candidatos a trabalhadores, - pertencentes a uma estrutura de raça, já que os brancos eram gerentes e os negros, trabalhadores -, deixavam suas famílias em seus locais de origem rurais, pois além do baixo salário, mantinham vínculos para um dia, voltarem.

16 MOODIE, T. D.; NDATSHE, V. Going for Gold: Men, Mines and Migration. Joanesburgo: Witwatersrand University Press, 1994. 
Dessa forma, os homens trabalhadores moravam em agrupamentos próximos às minas e, assim, precisavam cuidar do trabalho doméstico em seus agrupamentos. Se sexualmente ativos, procuravam parcerias sexuais - sejam mulheres que trabalhavam em cidades próximas, sejam outros homens dos agrupamentos. Geralmente, de acordo com Connell (2015), os homens mais jovens faziam trabalhos domésticos e ofereciam serviços sexuais em troca de proteção, presentes e dinheiro dos homens mais velhos.

Naquele contexto, ser homem significava assumir um papel próximo ao que conhecemos ser assumido pelas mulheres. Tanto homens quanto mulheres poderiam desempenhar funções iguais. A autora acrescenta:

Eles não estavam negando que em uma sociedade patriarcal, em última
instância, os homens detinham o controle, mas enfatizavam uma concepção
de parceria entre mulheres e homens na construção dos lares e
propriedades, em que as mulheres poderiam desempenhar, e de fato
desempenhavam, funções masculinas, participando, por conseguinte, desse
"ser homem" (CONNELL, 2015, p. 61).

No entanto, com o passar do tempo, essa estrutura foi alterada por mudanças históricoculturais e econômicas e as práticas de gênero também acabaram mudando. Há de se notar, assim, que mesmo sendo construída da mesma forma por séculos, ainda pode ser desconstruída.

As concepções de feminino e masculino e as justificativas para a naturalização de cada uma delas estão nos estereótipos do senso comum. Um dos livros ${ }^{17}$ mais vendidos no mundo, considerado best-seller, traduzido em 50 idiomas, que vendeu mais de 50 milhões de cópias, enfatiza a ideia de que homens e mulheres são de planetas diferentes, e que isso é natural, faz parte das características de cada sexo. Connell (2015) ressalta que essa diferença de gênero naturalizada ressalta padrões sociais de variados tipos (inclusive aqueles que utilizam justificativas "científicas").

Um deles é a dominância dos homens na sociedade, já que com seus altos níveis de testosterona eles têm uma "vantagem agressiva" hormonal na competição por cargos mais altos (CONNELL, 2015, p. 91).

Os estudos dessa autora mostram, também, que há muitos trabalhos em que aparecem essas "naturalizações" ou "biologizações" das diferenças entre gêneros.

Força física e velocidade (homens são mais fortes e mais velozes), habilidades físicas (homens têm habilidades mecânicas e mulheres são boas em tarefas trabalhosas), desejo sexual (homens têm mais libido), interesses recreativos (homens gostam de esportes e mulheres fazem fofoca), caráter (homens são agressivos e mulheres são cuidadosas), intelecto (homens são racionais e mulheres têm intuição), e assim por

17 Homens são de Marte; Mulheres são de Vênus, de John Gray, publicado pela primeira vez em 1992. 
diante. Acredita-se amplamente que essas diferenças sejam grandes e "naturais" (CONNELL, 2015, p. 91).

De fato, entre todos os indivíduos do mundo, há diferenças, mas elas estão relacionadas ao contexto social e mudam de acordo com o tempo. Connell (2015) fala em "corporificação social", que significa que os corpos são, ao mesmo tempo, agentes e objetos de uma estrutura social. Essa corporificação social abarca tanto o comportamento dos indivíduos, como também o de grupos e instituições. Dentro dessa perspectiva da autora, o conceito de gênero entra como uma "forma específica de corporificação social", ou seja, refere-se a "estruturas corporais e processos ligados à reprodução humana".

Assim, Connell (2015) conceitua a "arena reprodutiva", que trata de um espaço, o corpo, onde os fatos sociais se materializam, o que não é o mesmo que justificar biologicamente os mecanismos como naturais e "automáticos", mas é uma maneira de categorizar os gêneros, visto que somos uma das espécies que têm reprodução sexuada, mas a única que produziu relações sociais estruturais hierárquicas relacionadas a essas categorias. Sobretudo, o trabalho ressalta que a arena reprodutiva pode ser retrabalhada por processos sociais, como, por exemplo, a luta por métodos de contracepção, que descontrói um desses papéis impostos à mulher.

O conceito de arena reprodutiva não agrupa todos os significados de gênero, já que também se faz necessário o conceito de domínio de gênero. O domínio de gênero trata da ligação das esferas sociais com a arena reprodutiva, ou seja, de como as relações entre pessoas, grupos e objetos estão estruturadas segundo esse conceito, devido à configuração das relações de gênero, configuradas por essa dominação, que pode variar de uma sociedade à outra.

\subsection{Dominação de gênero}

Bourdieu (2017) também se refere à domínio de gênero, mostrando como estamos sujeitos aos diversos tipos de dominação masculina, histórica e culturalmente. Ele apresenta, analogamente, diversas oposições relacionadas à dicotomia masculino/feminino e superior/inferior, como

alto/baixo, em cima/embaixo, na frente/atrás, direita/esquerda, reto/curvo (e falso), seco/úmido, duro/mole, temperado/insosso, claro/escuro, fora (público)/dentro (privado) etc., que, para alguns, correspondem a movimentos do corpo (alto/baixo//subir/descer, fora/dentro//sair/entrar). Semelhantes na diferença, tais oposições são suficientemente concordes para se sustentarem mutuamente, no jogo e pelo jogo inesgotável de transferências práticas e metáforas; e também suficientemente divergentes para conferir, a cada uma, uma espécie de espessura semântica, nascida 
da sobredeterminação pelas harmonias, conotações e correspondências (BOURDIEU, 2017, p. 20).

Essas oposições, segundo o autor, fazem com que haja uma naturalização delas, de forma que nesse contexto, as divisões sexuais tornar-se-iam, também, naturais.

Bourdieu (2017) explica essa relação de dominação masculina pelo conceito de habitus, originado de Aristóteles, o qual ressignificou depois da década de 1960. Esse construto relaciona-se a um estado adquirido do caráter moral, que orienta nossa conduta. $\mathrm{A}$ noção de habitus estaria sob a forma de disposições determinadas por cada meio social e que norteiam as ações, os sentimentos e pensamentos dos indivíduos desse grupo (CATANI, 2017).

O conceito de habitus também está presente em outro trabalho (BOURDIEU, 2004), relacionado ao termo campo. De acordo com Bourdieu (2004), o campo, seja ele científico, literário ou artístico, é um espaço que possui leis próprias e específicas e relaciona-se às leis sociais, podendo exibir autonomias diferenciadas no que concerne a elas. Ele explica que

existe [...] o campo literário, artístico, jurídico ou científico, isto é, o universo no qual estão inseridos os agentes e as instituições que produzem, reproduzem ou difundem a arte, a literatura ou a ciência. Esse universo é um mundo social como os outros, mas que obedece a leis sociais mais, ou menos, específicas (BOURDIEU, 2004, p. 20).

Bourdieu (2004) exemplifica com a possibilidade de dois tipos de Ciência: a "pura", que seria livre de qualquer imposição, e a "escrava", que estaria sujeita a demandas políticoeconômicas. Sua teoria é a de que o campo científico é um mundo social e, por isso, sujeito, necessariamente, a imposições e solicitações cujo grau de independência do mundo social global define sua autonomia. A autonomia no âmbito de cada campo é definida, por sua vez, por forças ou lutas que levam integral ou parcialmente a relações de poder e dominação.

Os agentes sociais condicionados por essas forças definem as estruturas sociais, como também foi trabalhado no conceito de "corporificação social" de Connel (2015). Bourdieu (2004) explica, então, que esses agentes têm disposições adquiridas, habitus, isto é, formas de ser permanentes, duráveis. Essas disposições é que conformam as relações sociais que dominam cada campo.

O habitus, alimentado pela sociedade, pode levar a uma explicação para a constância das relações de dominação de gênero. O estado habitual e permanente do corpo construído socialmente, que tende a ser estável, causa a dificuldade de se estabelecerem mudanças significativas nas relações de gênero, contribuindo fortemente, a todo momento, para que essas características de dominação sejam objetivadas e naturalizadas. Assim, o habitus de 
gênero é incorporado desde cedo nos processos de socialização primária da criança, desde a família até a escola. Essas relações conduzem à objetivação de características, inculcando o lugar masculino e feminino na sociedade.

Chassot (2015), um pesquisador do campo do ensino de Ciências da Natureza, sugere que diversas influências históricas configuram muito da dominação masculina que se perpetua por séculos até hoje e influenciam o ensino nas escolas, conformam as crenças pessoais, além de serem disseminadas pelas várias mídias de comunicação social.

Esse autor apresenta como uma das possíveis explicações para a baixa presença de mulheres nas áreas das Ciências da Natureza e Exatas (salientando, ainda assim, que possa ser uma simplificação) as religiões de extração greco-judaica-cristã e a mitologia, as quais apresentam uma evidente falta de espaço para as mulheres, em relação aos homens, em suas lendas e histórias contadas. As mulheres representavam corpos, sexualidade, pecados, não estudavam, não trabalhavam e eram responsáveis por diversos males da humanidade. Ele coloca o que chama de ancestralidade greco-judaica-cristã como um pilar que sustenta fortemente a configuração das Ciências da Natureza e Exatas masculinas em nossa sociedade: na grega, os mitos e as concepções de Aristóteles, filósofo conhecido; na judaica, a cosmogonia, particularmente Adão e Eva; e, na cristã, a radicalidade de algumas explicações e interpretações, como as trazidas por Paulo de Tarso, Santo Agostinho, Santo Isidoro de Sevilha, Santo Tomás de Aquino e Leão XIII, dentre outros.

Entre os animais, é o ser humano o que possui o cérebro mais desenvolvido, em proporção com o seu tamanho; como também o cérebro é maior nos homens do que nas mulheres. É também o ser humano que apresenta, na cabeça, um maior número de suturas, no homem em quantidade superior à mulher, sempre pela mesma razão, isto é, para que essa região seja arejada, e quanto maior for o cérebro mais ventilação exige (Aristóteles, 2010, p. 79).

Aristóteles (1993, p. 104) ${ }^{18}$ ensinava - e essas concepções se sustentaram pelo menos até o fim da Idade Média - que a semente masculina estaria dotada de todas as características que teria o novo ser. Qualquer imperfeição que a nova criatura viesse a ter era responsabilidade da mulher [...]. Se da semente masculina nascesse uma fêmea, isso se devia a uma impotência de seu pai que então geraria um ser impotente: uma fêmea; assim, a mulher é ela própria um defeito (Chassot, 2015, p. 82).

Também entre os sexos, o macho é por natureza superior e a fêmea inferior, o macho governa e a fêmea é sujeita. Devendo o mesmo ser aplicado ao caso da espécie humana em geral [...] (Aristóteles, s/data, apud Chassot, 2015, p. 83) ${ }^{19}$.

Essas interpretações partem da constatação de diferenças físicas (ou de comportamento) entre homens e mulheres, para inferiorizá-las biologicamente, como se

${ }^{18}$ ARISTÓTELES. Parva Naturalia. Madrid: Alianza, 1993.

${ }^{19}$ ARISTÓTELES. A Política. Rio de Janeiro. Ediouro, s/ data. 
fosse natural que elas fossem "defeituosas" ou "incapazes" disso ou daquilo, o que também é parte da configuração do sexismo. Existem, de fato, construções sociais que a todo momento levam pessoas, sociedades e gerações inteiras a acreditarem que mulheres não podem ou não conseguem executar determinadas atividades, o que prescinde de caráter científico e, ainda menos, de modelos experimentais que sustentem essas crenças.

As concepções estereotipadas de "características ideais" que mulheres devem ter para serem bem sucedidas em determinadas carreiras como as Ciências da Natureza e Exatas, sobretudo a dicotomia "razão" e "emoção", características atribuídas social e essencialmente a homens e mulheres, respectivamente, são grandes responsáveis pelo afastamento delas das áreas científicas, já que moldam, socialmente, o que é ser cientista pelo construído como "natural" e, assim, alimentam a relação desigual de poder existente na sociedade e, por consequência, nessas áreas (FÁVERO, 2010).

Essas construções não só afastam as mulheres dessas carreiras, como acarretam em contextos discriminatórios (FÁVERO, 2010) quando elas já estão atuando nessas áreas, o que acaba, também, afastando-as posteriormente na forma de evasões, desistências e outros mecanismos.

Esse afastamento também se dá na dificuldade de alcance a maiores cargos na hierarquia acadêmica, o que se evidencia por uma barreira "invisível" e indireta denominada "teto de vidro", ideia que também é trabalhada por Londa Schiebinger (2001). Os paradigmas que conduziram aos modelos que norteiam as atuais atividades de pesquisa no campo das Ciências da Natureza e Exatas derivam de estudos desenvolvidos, majoritariamente, ao longo de boa parte de sua história, por homens brancos, ocidentais e associados às classes dominantes (LÖWY, 2009). Esse é um dos fatores que contribui para que se constitua essa barreira simbólica para a permanência das mulheres nessas áreas.

\subsection{O sexismo nas Ciências da Natureza e Exatas - Efeito Matilda}

Além da ideia que se tem sobre as mulheres e seus papeis e o quanto esses estereótipos influenciam a sociedade, no geral, há ainda o conceito sobre as Ciências da Natureza e Exatas e os cientistas que as exercem. O Centro de Gestão e Estudos Estratégicos e o Ministério da Ciência, Tecnologia e Inovação fizeram um estudo a respeito da percepção pública da Ciência e Tecnologia (C\&T) no Brasil, que apresenta dados acerca do interesse, acesso à informação, conhecimento, comportamentos, hábitos e atitudes das pessoas em relação à C\&T, distribuídos entre homens e mulheres (BRASIL, 2015). 
Uma das questões abordadas nessa pesquisa relacionava-se à imagem que se tem de cientistas: a maioria dos participantes do estudo acha que são "pessoas inteligentes que fazem coisas úteis à humanidade" (52,3\%), "pessoas comuns com treinamento especial" $(12,7 \%)$ ou "pessoas que se interessam por temas distantes da realidade das pessoas" $(10,3 \%)$. Há ainda uma parcela menor (3,3\%) que acha que são "pessoas excêntricas de fala complicada", entre outras percepções identificadas.

Outro questionamento feito foi se há alguma instituição que se dedique a fazer pesquisas científicas no Brasil: $87,6 \%$ das pessoas não lembram. Na pergunta: "Você se lembra do nome de algum cientista brasileiro importante?", 93,3\% responderam "não". Esses dados apontam para um distanciamento entre cientistas e população. Esse estereótipo, adicionado àquele referente às mulheres e sua suposta "natureza", indica motivações para que o exercício de atividades voltadas a esse campo do conhecimento ainda seja uma meta distante para as mulheres brasileiras.

Apesar de todos os obstáculos, que incluem séculos de exclusão da instrução formal ao longo da história, muitas mulheres resistiram e resistem, até hoje, nesses campos. Algumas das poucas que conseguiam estudar, ingressavam em áreas científicas. No século XIII, primeiramente na Itália, algumas mulheres ingressaram na Física e na Matemática, consideradas, até hoje, áreas especialmente resistentes às incursões femininas.

Somente no século XVIII, em 1732, Laura Bassi, física, tornou-se a segunda mulher na Europa a receber um grau universitário (depois da veneziana Elena Cornaro Piscopia, em 1678) e a primeira a ser agraciada, na Europa, com uma cadeira na universidade.

No entanto, muitas das mulheres que, ainda com todos os empecilhos, ingressam nessas áreas científicas, acabam afrontando diversas dificuldades ao longo da carreira. Uma delas é sua total invisibilidade na área, o que também faz parte da violência simbólica.

Muitas das mulheres que participaram de diversos estudos e pesquisas não receberam o devido reconhecimento, o que significa que, muitas vezes, não se sabe nem que elas existiram naqueles trabalhos, naqueles grupos de pesquisa, quanto mais que tenham contribuído para determinados feitos ou protagonizado descobertas de importantes realizações científicas.

Por exemplo, Margaret W. Rossiter ${ }^{20}$, historiadora da Ciência, estava pesquisando trabalhos científicos americanos, quando percebeu que no livro American Men of Science ${ }^{21}$ estavam ocultas as biografias de cerca de 500 mulheres cientistas. A partir desse momento,

\footnotetext{
20 Disponível em: <https://en.wikipedia.org/wiki/Margaret_W._Rossiter>. Acesso em: 09 set. 2017.

${ }^{21}$ Hoje o livro chama-se "American Men and Women of Science".
} 
ela começa diversas análises sobre esse mecanismo de camuflar a participação de mulheres nas Ciências da Natureza e Exatas e cunha o termo que se relaciona a esse efeito de diminuir, menosprezar e invisibilizar as mulheres que tiveram participação na área científica, como Efeito Matilda. O efeito homenageia Matilda Electa Gage, feminista ativista que o descreveu em meados do século XIX.

A expressão tem origem no Efeito Matthew, que foi nomeado pela sociologia como o ato de creditar cientistas que tenham mais destaque que outros, mesmo que os merecedores, de fato, desses créditos, sejam esses desconhecidos. O mais irônico é que o próprio Efeito Matthew também teve Efeito Matilda, uma vez que a socióloga da Ciência Harriet Zuckerman teve importante participação no estudo Matthew e não teve o mesmo reconhecimento que o sociólogo Merton, nome frequentemente associado ao trabalho (LIMA, 2013).

Podem-se citar milhares de exemplos de mulheres cientistas cujos trabalhos foram ocultos ou roubados, não recebendo os devidos créditos. Rosalind Franklin, Alice Ball, Marietta Blau, Lise Meitner, Esther Lederberg, entre muitas outras. Marie Curie, apesar de sua grande popularidade, é frequentemente associada a seu marido Pierre Curie como sua assistente e como mera participante de descobertas científicas pelas quais ela é reconhecidamente responsável. 


\title{
5. Metodologia
}

\subsection{A História Oral}

A metodologia de pesquisa adotada neste trabalho baseia-se nos preceitos da História Oral (HO). Ela se baseia na realização de entrevistas com pessoas que possam explicitar informações importantes em seus relatos pessoais, que levem à compreensão de fatos do passado e do presente.

\begin{abstract}
História Oral é uma prática de apreensão de narrativas feita através do uso de meios eletrônicos e destinada a: recolher testemunhos, promover análises de processos sociais do presente e facilitar o conhecimento do meio imediato. [...] História Oral é uma alternativa para estudar a sociedade por meio de uma documentação feita com o uso de entrevistas gravadas em aparelhos eletrônicos e transformadas em textos escritos [...] (MEIHY; HOLANDA, 2013, p. 18).
\end{abstract}

Uma vez que as entrevistas podem ser documentais em um determinado momento histórico, a História Oral, assim, adquire caráter transformador e está diretamente ligada a realidades sociais e culturais (MEIHY, 2006).

Durante todas as fases de execução da história oral temos um compromisso com a transformação sem o que a história oral não tem razão de ser. Sem isso, aliás, não se tem história oral e sim o velho e consagrado uso de entrevistas de cunho testemunhal. A novidade aqui proposta se efetiva na superação do limite culturalista. Porque se credita ao saber universitário, acadêmico, mais do que compreender; assume-se o compromisso com o social como princípio, meio e fim da história oral. O destino transformador, portanto, é a marca de honra da história oral (MEIHY; HOLANDA, 2013, p. 108).

O contexto do desenvolvimento da História Oral parte da Ditadura Militar no Brasil após a Campanha pela Anistia e depois da Abertura Política, pois nasce da importância de registrar as memórias de todo o tempo difícil daquela época (MEIHY; HOLANDA, 2013). A abordagem da $\mathrm{HO}$ foi utilizada pela primeira vez, no Brasil, na década de 1970, pelo Centro de Pesquisa e Documentação de História Contemporânea do Brasil (CPDOC) da Fundação Getúlio Vargas (FGV) do Rio de Janeiro (MEIHY, 1999).

Para a realização da História Oral, há seis momentos principais que podem ser distribuídos da seguinte forma: 1) elaboração do projeto, 2) gravação, 3) estabelecimento do documento escrito e sua seriação, 4) eventual análise, 5) arquivamento e 6) devolução social (MEIHY; HOLANDA, 2013). A elaboração do projeto é a definição de todos os critérios de procedimentos, inclusive decidindo se haverá continuação após a realização da 
entrevista, como possíveis transcrições literais ou transcriações, conceito proposto por Haroldo de Campos (1977).

$\mathrm{Na}$ transcriação, opta-se pela maior adesão ao conteúdo, em vez da forma, ou seja, transforma-se o relato oral em texto, minimizando interferências, como possíveis vícios de linguagem, frases confusas e pausas durante a fala, que se constituiriam em distratores no texto escrito. Ao se transportar a mensagem de um suporte semiótico para outro, é praticamente impossível ser fiel a ambos aspectos. Haroldo de Campos (1977) explica que:

$\mathrm{Na}$ tradução de um poema, o essencial não é a reconstituição da mensagem, mas a reconstituição do sistema de signos em que está incorporada esta mensagem, da informação estética, não da informação meramente semântica (CAMPOS, 1977).

Para além dessa questão, segundo Meihy e Holanda (2013, p. 158), a transcriação proporciona "uma visão geral das ficcionalidades enquanto memória, fala, transcrição, textualização e interpretação".

O segundo passo, o instante da gravação, é a primeira realização, de fato, do projeto. Deve-se decidir onde será a gravação, quem fará parte dela e quais serão os meios de armazenamento e arquivamento do relato. No terceiro passo, haverá a confecção do documento escrito, seja qual for o tipo de transcrição escolhido. A análise terá relação com os procedimentos escolhidos. Meihy e Holanda (2013) explicam que existe uma linha que trabalha História Oral que "considera o leitor como um agente ativo, que, ao ler uma entrevista, não precisa ser conduzido a conclusões que ele saberá elaborar' (p. 31), o que certamente dá mais autonomia ao leitor em relação à análise e interpretação do texto transcriado.

Por fim, o arquivamento, que tem relação com a responsabilidade com o material, e a devolução social, segundo Meihy e Holanda (2013),

[..] diz respeito aos compromissos comunitários requeridos pela História Oral que, sempre, deve prever o retorno ao grupo que a fez gerar. Seja em forma de livro, exposição ou mesmo de doação dos documentos confeccionados, a devolução é capital (MEIHY; HOLANDA, 2013, p. 31).

Meihy e Holanda (2013) também apontam para a observação de que a História Oral não se trata apenas de meras entrevistas, mas de um registro que parte do oral para o escrito e transforma-se em texto que será analisado, registrado e/ou arquivado. Além disso, a HO pressupõe decisões acerca das circunstâncias em que as entrevistas serão realizadas: por exemplo, quais os espaços e tempos e se haverá estímulos externos estruturando o relato ou não. 
A História Oral é dividida em três vertentes: História Oral de vida, História Oral temática e tradição oral. Resumidamente, a primeira trata de relatos de vida, narrativas pessoais que contem histórias de vida. A segunda pressupõe um ponto de partida específico e, por isso, em geral, utilizam-se questionários e entrevistas estruturadas. Por último, a tradição oral se assenta em elementos de memória coletiva, voltando-se à vida de grupos, o que não seria possível somente através de entrevistas (MEIHY; HOLANDA, 2013). Neste trabalho, empregou-se a vertente da História Oral de vida.

\subsection{História Oral de vida}

A vertente da História Oral chamada por Meihy e Holanda (2013) de História Oral de vida é também chamada de biografia, relato de vida, relato biográfico, nota biográfica, narrativa autobiográfica, ou mesmo autobiografia.

Os relatos de vida ou as autobiografias foram escritas desde a Antiguidade até séculos depois: por Santo Agostinho, entre os séculos IV e $\mathrm{V}$ e depois por filósofos mais conhecidos como Rousseau (século XVIII). Entretanto, muito antes disso, por volta de 1365, uma mulher, Christine de Pisan, começou a abrir caminhos para histórias de vida femininas. Meihy e Holanda (2013) dizem que esse registro é importante "porque desloca o olhar masculino e masculinizante" (p. 36) que marcou o surgimento dessa vertente da História Oral.

Christine de Pisan, poeta francesa, foi uma das primeiras escritoras notáveis da época medieval. Em 1399, em sua obra "Epistre au dieu d'amour", ela explora o status da mulher na sociedade, na Educação e a representação feminina na literatura22. Em 1405, ela escreve "La cité des dames", um dos primeiros textos feministas. O que é mais notável em sua obra é que, além de falar da situação das outras mulheres, ela também falava de si: de seus sentimentos, de sua vida e das dores que ela sentia pela morte de seu marido.

A partir do século $X X$, a história de vida passa a ser incorporada às práticas acadêmicas como documento, uma vez que grupos de imigrantes, que não possuíam documentos suficientes, eram estudados por meio de relatos biográficos. A ideia da História Oral e, mais ainda, da história de vida, é a valorização do indivíduo em detrimento do exclusivismo da estrutura social (MEIHY; HOLANDA, 2013).

22 Disponível em: <https://www.biography.com/people/christine-de-pisan-9247589>. Acesso em: 17 set. 2017. 
Uma das possíveis histórias de vida é a autobiografia, que se dá por meio da voz da narradora, que é quem está contando a própria história e faz as possíveis relações dos fatos. Há, assim, uma autonomia e uma independência da(o) entrevistada(o). Maria Isaura Pereira de Queiroz (1988) explica que:

Narrar a própria existência consiste numa autobiografia, e toda história de vida poderia, a rigor, ser enquadrada nesta categoria tomada em sentido lato. Mas, no sentido restrito, a autobiografia existe sem nenhum pesquisador, e é essa sua forma específica (QUEIROZ, 1988).

Assim, entendendo a autobiografia como "autosuficiente" em relação ao pesquisador, a ideia da narrativa autobiográfica dentro das entrevistas é dada de forma que as convidadas possam falar livremente sobre suas trajetórias, enfatizando os pontos que acharem importante mencionar, com o mínimo de interferência do pesquisador, que deve registrar tudo da melhor forma possível.

A partir de relatos sobre a trajetória pessoal, é possível compreender quais fatos do passado e do presente foram/são relevantes para o tema investigado, já que a autobiografia no contexto da História Oral parte de cada voz que cede seu relato profissional ou pessoal, auxiliando, assim, na abordagem de aspectos sociais e culturais mais amplos, como a questão das mulheres na sociedade e, mais especificamente, nas Ciências da Natureza e Exatas.

Neste trabalho, as informações foram coletadas por meio de entrevistas com nove mulheres cientistas. As entrevistas foram narrativas de cunho autobiográfico, em que as convidadas falaram sobre suas trajetórias de vida, enfatizando os pontos que acharam importante mencionar, com o mínimo de interferência da pesquisadora.

As entrevistadas são mulheres cientistas acadêmicas, de diferentes faixas etárias, vinculadas a universidades públicas, das áreas de Bioquímica, Matemática e Física. Elas foram escolhidas para se ter uma diversidade de idades, gerações, áreas das Ciências da Natureza e Exatas e momentos diferentes da carreira. Foi importante a escolha de cientistas acadêmicas e não que estivessem no mercado de trabalho, por exemplo, por razão da possibilidade de maior estabilidade na carreira.

Durante a procura por mulheres cientistas que aceitassem ser entrevistadas, procurouse abarcar uma amostra o mais abrangente possível, em termos de localidade geográfica no Brasil, classe social familiar, tipo de contrato na universidade, área de pesquisa, cargos, raça e etnia, diferença de gerações e de estados civis, mulheres cis e trans ${ }^{23}$. Infelizmente,

23 O termo transexual ou transgênero surge na década de 1920 pelos médicos que patologizavam pessoas que não se "identificavam" com o gênero predito por seu genital (vagina/mulher, pênis/homem). Em outras palavras, são pessoas que não têm necessariamente os corpos entendidos 
nem todas as mulheres cientistas convidadas aceitaram participar. Das nove entrevistadas, uma é negra e todas são mulheres cis. Mais adiante, serão caracterizados outros aspectos de suas vidas pessoais.

\begin{tabular}{|c|c|c|}
\hline Mulheres entrevistadas $^{\mathbf{a}}$ & $\begin{array}{c}\text { Departamentos } \\
\text { das universidades }\end{array}$ & Titulações \\
\hline Alice & Bioquímica & Professora Titular \\
\hline Annie & Matemática & Professora Doutora \\
\hline Enedina & Bioquímica & Professora Titular \\
\hline Grace & Bioquímica & Professora Associada \\
\hline Juliana & Matemática & Professora Doutora aposentada \\
\hline Nagwa & Bioquímica & Professora Titular \\
\hline Nise & Física & Professora Adjunta \\
\hline Rosalind & Estatística & Professora Doutora \\
\hline Stephanie & Física & Professora Titular \\
\hline
\end{tabular}

Quadro 2: Caracterização profissional das mulheres entrevistadas.

a. Os nomes são fictícios e fazem referência às mulheres cientistas do Anexo 2 (p. 102).

Todas as entrevistas foram realizadas nos locais de trabalho de cada uma delas, com exceção de duas professoras que, por atuarem em estados diferentes do local em que se encontrava a pesquisadora, foram entrevistadas por chamadas de vídeo pela internet. Todas as entrevistas foram gravadas em formato de áudio, transcritas, transcriadas e, em seguida, submetidas às entrevistadas para sua validação. Nesta etapa, as professoras que colaboraram com a pesquisa poderiam alterar o que considerassem necessário. Todas autorizaram a utilização do conteúdo do texto final de suas entrevistas, assinando o documento do Anexo 1 (p. 101).

social e culturalmente como masculinos ou femininos. Vale ressaltar que a transexualidade está até hoje (como "transexualismo") na lista de transtornos mentais da Classificação Estatística Internacional de Doenças e Problemas Relacionados à Saúde - CID 10 da Organização Mundial da Saúde OMS). Uma vez que se cunhou pessoas trans como doentes por suas identidades entendidas como "não-biológicas", o restante passa a ser automaticamente categorizado como "normal" ou "biológico", o que patologiza ainda mais as pessoas trans. Dessa forma, o termo cisgênero começa a ser utilizado na década de 1990 pela comunidade trans como classificação política daqueles que as/os nomearam, já que, segundo Hailey Kaas (Disponível em: <https://transfeminismo.com>. Acesso em: 08 dez. 2017), "uma pessoa cis é aquela que politicamente mantém um status de privilégio em detrimentos das pessoas trans, dentro da cisnorma. Ou seja, ela é politicamente vista como 'alinhada' dentro de seu corpo e de seu gênero". Apesar de os dois prefixos, cis e trans, indicarem etimologicamente "estar do mesmo lado" e "cruzar para o outro lado", respectivamente, Hailey Kaas ressalta a importância de não dicotomizar pessoas cis/trans, assim como sexo/gênero, já que o significado é mais amplo do que a simples identificação de si ou não com a genitália de nascimento (identificação esta que é bastante subjetiva). 
Normalmente, é necessário que mais de uma entrevista seja realizada com cada uma das pessoas para que se chegue ao texto final, que será o documento a ser aprovado pela entrevistada e submetido à análise. Assim, pode-se garantir que caso haja algum ponto da entrevista que não tenha ficado claro, que este seja revisto e novamente conversado. Foram feitos dois encontros com oito das nove ${ }^{24}$ entrevistadas para aprofundamento de algumas informações contidas na primeira entrevista.

\subsection{Caracterização dos sujeitos de pesquisa}

O público-alvo deste trabalho é o de mulheres cientistas brasileiras acadêmicas de diferentes faixas etárias, vinculadas a universidades públicas. São da área de Química, Bioquímica, Matemática e Física, sendo que, em cada um dos grupos, há pessoas em momentos diferentes da carreira.

Foram realizadas nove entrevistas. O primeiro ciclo de entrevistas foi feito no segundo semestre de 2015. O segundo ciclo realizou-se no segundo semestre de 2017. Em todas as entrevistas, pediu-se que as convidadas começassem a contar, de forma aberta, sua trajetória de vida. A pesquisadora fez o mínimo de intervenções, deixando que as convidadas falassem livremente.

Neste trabalho, por sigilo, as entrevistadas não estão designadas por seus nomes reais. Para dar mais vida aos relatos, optou-se por substituir os nomes das entrevistadas por nomes de cientistas importantes do mundo. É importante salientar que não houve qualquer intenção de escolha por semelhanças com as entrevistadas, ao propor a cientista cujo nome seria escolhido.

No Anexo 2 (p. 102), há uma caracterização das cientistas homenageadas, contando um pouco de suas trajetórias. São elas: Alice Augusta Ball, Annie Jump Cannon, Enedina Alves, Grace Hopper, Juliana Rotich, Nagwa Abdel Meguid, Nise da Silveira, Rosalind Franklin e Stephanie Kwolek.

As entrevistadas têm trajetórias científico-acadêmicas que envolvem a obtenção dos títulos de Graduadas, Mestras, Doutoras, Livre-docentes e Professoras Titulares. Muitas das entrevistadas realizaram estágios de pós-doutorado no exterior. As áreas de trabalho

24 Somente uma das entrevistadas não cedeu o segundo relato, pois esteve viajando durante a realização das entrevistas. 
(departamentos), bem como os cargos nas universidades públicas onde cada uma das mulheres entrevistadas trabalha, estão organizados no Quadro 2.

\subsection{Análise de conteúdo}

A análise do texto final transcriado inspirou-se nos preceitos da análise de conteúdo proposta por Bardin (1977) para a construção de categorias, que emergem das leituras sucessivas de cada uma das entrevistas de acordo com os critérios léxicos e semânticos propostos por essa autora.

A análise de conteúdo já era utilizada desde os tempos antigos: a hermenêutica, vertente da filosofia, baseava-se na interpretação tanto da linguagem verbal como da nãoverbal, que é o princípio do método. Segundo Bardin (1977, p. 14), "por detrás do discurso aparente geralmente simbólico e polissêmico esconde-se um sentido que convém desvendar". O processo de interpretação, de acordo com a autora, passa por diversos temas desde a interpretação de sonhos, a explicação crítica de diversos textos literários, até a astrologia e a psicanálise.

Essa interpretação continua a existir na análise de conteúdo, mas com procedimentos mais técnicos. Esse tipo de análise começa a se desenvolver no início do século XX nos Estados Unidos com materiais jornalísticos e publicitários e, após a Segunda Guerra Mundial, com materiais de investigação política.

[...] durante os anos da guerra, o Governo americano exortou os analistas a desmascararem os jornais e periódicos suspeitos de propaganda subversiva (principalmente nazi) (BARDIN, 1977, p. 16).

No final dos anos 1940/1950, a definição de análise de conteúdo por Berelson (1952)25 apud Bardin (1977, p. 19) era: "[...] é uma técnica de investigação que tem por finalidade a descrição objetiva, sistemática e quantitativa de conteúdo manifesto da comunicação". Posteriormente, essa definição foi complementada por trabalhos de analistas americanos/as e franceses/as e, após intensos debates sobre a análise de conteúdo ser quantitativa ou qualitativa, estabeleceu-se que há, hoje, as duas abordagens. Na primeira, a informação é da frequência com que surgem determinadas características do conteúdo. Na segunda, é a presença ou a ausência desses atributos (BARDIN, 1977). A autora define a intenção da análise de conteúdo como "a inferência de conhecimentos relativos às condições de produção (ou, eventualmente, de recepção), inferência esta que recorre a indicadores 
(quantitativos ou não)" (p. 38). Assim, Bardin (1977) diz que há saberes deduzidos dos conteúdos, que podem ser de natureza psicológica, sociológica, histórica e econômica, o que confere finalidade implícita ou explícita à análise de conteúdo.

A autora propõe três eixos definidos como fases da análise. 1) a pré-análise; 2) a exploração do material; 3) o tratamento dos resultados, a inferência e a interpretação. 0 primeiro refere-se a organizar e sistematizar as ideias iniciais, já esquematizando as possíveis decisões. Na etapa referente ao segundo item executam-se as decisões tomadas e, por fim, o terceiro cuidará dos resultados (BARDIN, 1977, p. 95).

Apesar de não ser uma etapa obrigatória, a maioria dos trabalhos em que se utiliza a análise de conteúdo como método envolve o processo chamado de categorização. Trata-se de classificar os elementos constitutivos de um conjunto, de acordo com critérios préestabelecidos; baseia-se, principalmente, na divisão do texto completo em fragmentos de texto menores, atribuindo significado a eles e contextualizando-os em classificações comuns. Segundo Bardin (1977, p. 117), o critério de categorização

pode ser semântico (categorias temáticas: por exemplo, todos os temas que
significam a ansiedade, ficam agrupados na categoria <ansiedade>,
enquanto que os que significam a descontração, ficam agrupados sob o
título conceitual <descontração >), sintático (os verbos, os adjetivos), léxico
(classificação das palavras segundo o seu sentido, com emparelhamento
dos sinônimos e dos sentidos próximos) e expressivo (por exemplo,
categorias que classificam as diversas perturbações da linguagem)
(BARDIN, 1977, p. 118).

Para iniciar a categorização, adotam-se pelo menos alguns dos critérios estabelecidos pela autora, como exaustividade (refere-se à permanência de todos os elementos presentes no material, sem nada ser deixado de fora por motivos quaisquer), representatividade (rigor na amostra), homogeneidade (os documentos devem obedecer aos critérios estabelecidos) e pertinência (adequação do material em relação ao objetivo proposto).

Com a categorização, a análise do texto fica mais concentrada no que, de fato, é essencial ser interpretado a partir do texto.

\subsection{Estatísticas textuais como ferramenta na análise de conteúdo}

A partir de análises que enfocam textos escritos, como é o caso do presente trabalho, que parte do texto transcrito e transcriado do relato, é possível realizar estatísticas textuais, 
que ajudam a evidenciar pontos importantes na entrevista. Assim, após a categorização, utilizou-se um software denominado IRAMUTEQ ${ }^{26}$.

A partir da década de 1990, o uso de softwares popularizou-se e, anos depois, o IRAMUTEQ foi desenvolvido por Pierre Ratinaud inicialmente em língua francesa e, posteriormente, introduzido no Brasil em 2013. O IRAMUTEQ é um software gratuito e de livre acesso, que viabiliza a realização de estatísticas textuais, de forma que é possível verificar a frequência de determinados pares de palavras citados no relato. Com essa ferramenta, podem-se construir "árvores" de palavras, que são representações gráficas de matrizes de co-ocorrência simples: as palavras mais citadas ficam em destaque, ligando-se às demais (vide Figuras 2 a 10). Esse método é chamado de análise de similitude.

A junção da categorização com os resultados do IRAMUTEQ é interessante, pois é capaz de evidenciar a partir da classificação do texto e das árvores obtidas as ideias chave e semelhantes entre as entrevistas de forma geral.

Em suma, a análise da pesquisadora começa desde o relato escutado, transcrito, transcriado, categorizado e contextualizado, até a observação e interpretação dos grafos obtidos pelo IRAMUTEQ, que mostram a conexão entre as palavras no texto, o que dá mais significado ainda ao que foi dito explicitamente ou implicitamente na entrevista.

26 Interface de R pour les Analyses Multidimensionnelles de Textes et de Questionnaires, 2008. 


\section{Resultados}

As entrevistas não estão apresentadas na íntegra neste trabalho a pedido das entrevistadas (como são todas cientistas acadêmicas, com as informações que apresentamos aqui, ficaria fácil identificá-las). Apresentaremos alguns trechos importantes para a análise, adiante.

Em todos os relatos das nove entrevistadas, elas iniciaram, de maneira geral, com a narração da infância e adolescência, seguindo para as escolhas profissionais e a descrição de como chegaram ao ponto da carreira que estão hoje, destacando momentos que elas acharam importante mencionar.

As categorias pensadas na análise de conteúdo emergiram dos textos após a transcriação deles. Esse procedimento teve por objetivo dar significado e encontrar partes comuns entre os relatos, para depois relacioná-las à estatística textual e interpretar os dados. Segundo a proposta de Bardin (1977) apresentada anteriormente, a categorização foi feita baseada em critérios semânticos.

\subsection{Categorização}

Foram observadas três categorias principais com duas subcategorias em cada uma delas, como mostra o Quadro 3. Nos Quadros 4, 5 e 6, são apresentadas a categorização dos relatos com suas descrições e alguns exemplos de passagens das histórias de vida das entrevistadas.

\begin{tabular}{|c|c|}
\hline Categorias & Subcategorias \\
\hline Escolha profissional & $\begin{array}{c}\text { Vocação } \\
\text { Influências afetivas }\end{array}$ \\
\hline Permanência na carreira & $\begin{array}{c}\text { Características pessoais } \\
\text { Influências externas }\end{array}$ \\
\hline Momentos marcantes durante a carreira & $\begin{array}{c}\text { Desafios e dificuldades } \\
\text { Prêmios e promoções }\end{array}$ \\
\hline
\end{tabular}

Quadro 3: Categorização elaborada a partir dos dados obtidos. 


\section{Categoria: Escolha profissional}

Apresenta os motivos que levaram as entrevistadas à escolha profissional.

\begin{tabular}{|c|c|c|}
\hline Subcategorias & Critérios & Excertos \\
\hline Vocação & $\begin{array}{l}\text { Remete a escolhas } \\
\text { pela carreira científica } \\
\text { que partiram da } \\
\text { afinidade pessoal com } \\
\text { a área escolhida. }\end{array}$ & $\begin{array}{l}\text { "[...]na verdade, eu nem sei muito bem por quê } \\
\text { eu escolhi fazer Biologia, mas matéria é aquela } \\
\text { coisa na escola, a gente gosta de uma matéria } \\
\text { mais do que da outra [...]" - Grace } \\
\text { "[...] sempre gostei de Ciências e eu gostava } \\
\text { de Química, era tudo coisa fantasiosa quando } \\
\text { criança, laboratório, alquimia, essas coisas. [...]" } \\
\text { - Nagwa }\end{array}$ \\
\hline $\begin{array}{l}\text { Influências } \\
\text { afetivas }\end{array}$ & $\begin{array}{l}\text { São escolhas } \\
\text { profissionais que } \\
\text { tiveram por base a } \\
\text { influência de alguém, } \\
\text { seja a família, amigos } \\
\text { ou mesmo professores } \\
\text { da escola. }\end{array}$ & $\begin{array}{l}\text { "[...] Eu tive um professor de Matemática que } \\
\text { foi muito marcante [...]. E esse professor me } \\
\text { estimulava muito... ele gostava de mim, mas eu } \\
\text { acho que a forma como ele ensinava } \\
\text { Matemática me estimulava muito, estimulava } \\
\text { a minha criatividade. [...]" - Annie } \\
\text { "[...] meu pai foi sempre um 'consertador' de } \\
\text { coisas. Ele consertava tudo dentro de casa e } \\
\text { [...] eu fui experimentando manusear coisas, } \\
\text { consertar coisas". - Stephanie }\end{array}$ \\
\hline
\end{tabular}

Quadro 4: Categorização de termos a partir dos relatos sobre a escolha profissional das entrevistadas.

\section{Categoria: Permanência na carreira}

Refere-se aos mecanismos desenvolvidos ou outros fatores que tenham contribuído para a permanência na carreira.

\begin{tabular}{|c|c|c|}
\hline Subcategorias & Critérios & Excertos \\
\hline $\begin{array}{c}\text { Características } \\
\text { pessoais }\end{array}$ & $\begin{array}{l}\text { Essa subcategoria } \\
\text { explica que a } \\
\text { permanência na } \\
\text { carreira científica pode } \\
\text { se dar por aptidão por } \\
\text { aquela área, gosto, } \\
\text { afinidade, vontade de } \\
\text { seguir a carreira ou } \\
\text { mesmo pelas } \\
\text { narradoras terem } \\
\text { desenvolvido } \\
\text { mecanismos que } \\
\text { facilitaram a } \\
\text { permanência delas } \\
\text { mesmo frente a alguns } \\
\text { obstáculos. }\end{array}$ & 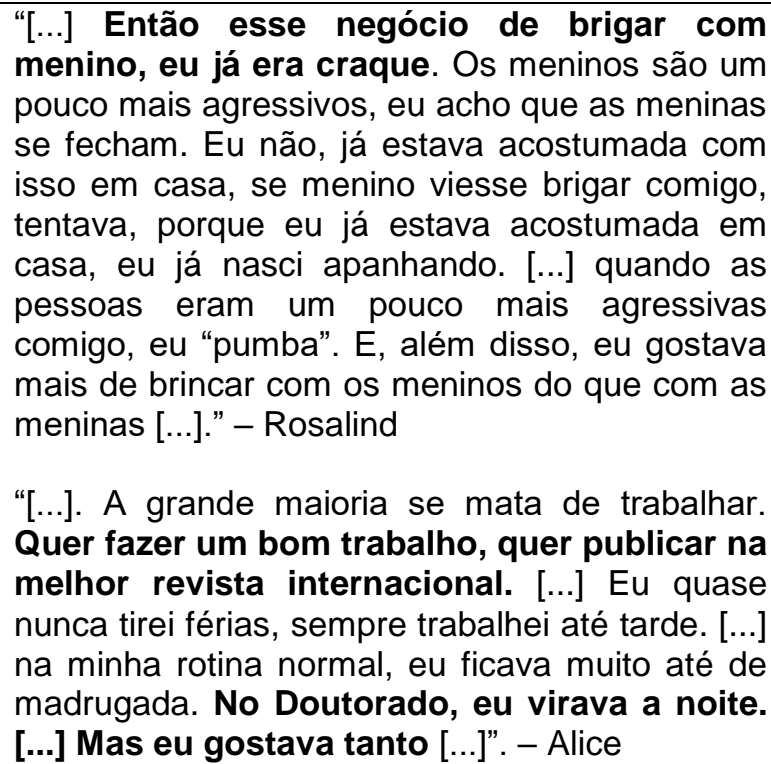 \\
\hline
\end{tabular}




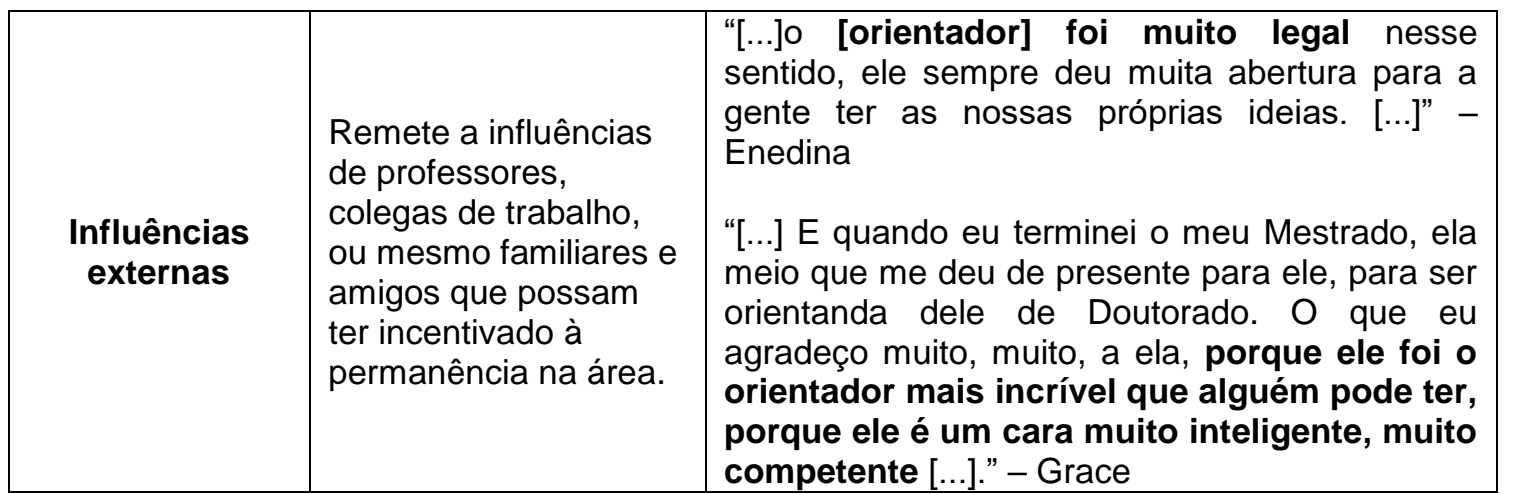

Quadro 5: Categorização de termos a partir dos relatos sobre a permanência na carreira das entrevistadas.

\section{Categoria: Momentos marcantes durante a carreira}

São os momentos que mais marcaram a trajetória das entrevistadas.

\begin{tabular}{|c|c|c|}
\hline Subcategorias & Critérios & Excertos \\
\hline $\begin{array}{c}\text { Desafios e } \\
\text { dificuldades }\end{array}$ & $\begin{array}{l}\text { Remete a } \\
\text { dificuldades que } \\
\text { poderiam tê-las } \\
\text { desanimado ao } \\
\text { longo da carreira. } \\
\text { Aqui estão inclusas } \\
\text { situações de } \\
\text { discriminações de } \\
\text { gênero. }\end{array}$ & $\begin{array}{l}\text { "[...] Eu realmente trabalhei muito, mas eu também } \\
\text { cuidei muito de filho, e quando a gente cuida } \\
\text { muito de filho não dá tempo de fazer tanta } \\
\text { pesquisa quanto a gente quer, não tem jeito, não } \\
\text { tem jeito, não adianta, que mulher que cuida de } \\
\text { filho, que leva e traz, que faz e acontece, que leva } \\
\text { no médico [...]". - Juliana } \\
\text { "[...] Quando eu entrei no Doutorado, foi muito } \\
\text { interessante, porque eu entrei para o ensino de } \\
\text { Ciências e eu não esqueço uma coisa que ele [um } \\
\text { colega] falou, porque era uma universidade de } \\
\text { prestígio onde eu estudei no Doutorado. Ele: [...] } \\
\text { Ah, mas para a área de ensino, eu acho que } \\
\text { Harvard é melhor, não é?" [...]. Qualquer coisa que } \\
\text { eu consiga, ele tenta diminuir. Que coisa } \\
\text { impressionante isso. Mas isso acontece. [...]"- } \\
\text { Nise }\end{array}$ \\
\hline $\begin{array}{l}\text { Prêmios e } \\
\text { promoções }\end{array}$ & $\begin{array}{l}\text { São pontos altos } \\
\text { na carreira, que } \\
\text { deram impulso } \\
\text { para permanecer } \\
\text { na área, ou, de } \\
\text { alguma forma, } \\
\text { marcaram a } \\
\text { trajetória } \\
\text { positivamente. }\end{array}$ & $\begin{array}{l}\text { "[...] Nessa trajetória, eu me tornei a coordenadora } \\
\text { e assessora de Física e Astronomia [...]. Eu fui a } \\
\text { primeira mulher na área [...]." - Stephanie } \\
\text { "[...] fiz uma série de coisas, fiz uns trabalhos } \\
\text { muito bons que foram publicados em ótimas } \\
\text { revistas e tiveram altos índices de citação. [...]"- } \\
\text { Nagwa }\end{array}$ \\
\hline
\end{tabular}

Quadro 6: Categorização de termos a partir dos relatos sobre momentos marcantes na carreira das entrevistadas. 


\subsection{Caracterização das entrevistadas}

Ao final dos relatos, algumas perguntas foram feitas às entrevistadas no intuito de organizar melhor a análise dos dados (Quadro 7), como estado civil, ano de conclusão de estudos e ano de nascimento dos/as filhos/as.

\begin{tabular}{|c|c|c|c|c|c|c|}
\hline & Idade & $\begin{array}{c}\text { Estado } \\
\text { civil }\end{array}$ & $\begin{array}{l}\text { Filho/a } \\
\text { (idade) }\end{array}$ & $\begin{array}{c}\text { Ano de } \\
\text { conclusão } \\
\text { Graduação }\end{array}$ & $\begin{array}{c}\text { Ano de } \\
\text { conclusão } \\
\text { Mestrado }\end{array}$ & $\begin{array}{c}\text { Ano de } \\
\text { conclusão } \\
\text { Doutorado }\end{array}$ \\
\hline Alice & 77 & Divorciada & Não & 1962 & - & 1969 \\
\hline \multicolumn{7}{|c|}{ Foi casada de 1970 a 1973.} \\
\hline Annie & 37 & Solteira & Não & 2001 & 2004 & 2008 \\
\hline \multicolumn{7}{|c|}{ União estável de 2008 a 2015.} \\
\hline Enedina & 43 & Solteira & Não & 1997 & - & 1999 \\
\hline \multicolumn{7}{|c|}{-} \\
\hline Grace & 49 & Divorciada & $\operatorname{Sim}(14)$ & 1989 & 1993 & 1997 \\
\hline \multicolumn{7}{|c|}{ Foi casada de 2002 a 2012. Filho nasceu em 2003.} \\
\hline Juliana & 58 & $\begin{array}{c}\text { Divorciada } \\
\text { (união } \\
\text { estável } \\
\text { atualmente) }\end{array}$ & $\begin{array}{c}\operatorname{Sim}(31 \\
\text { e 26) }\end{array}$ & 1981 & 1989 & 1998 \\
\hline \multicolumn{7}{|c|}{ Foi casada de 1981 a 2005. Filhos nasceram em 1986 e em 1991.} \\
\hline Nagwa & 69 & Solteira & Não & 1971 & - & 1975 \\
\hline \multicolumn{7}{|c|}{ Teve união estável. } \\
\hline Nise & 39 & Solteira & Não & 2002 & 2006 & 2012 \\
\hline \multicolumn{7}{|c|}{-} \\
\hline Rosalind & 55 & Casada & $\begin{array}{c}\operatorname{Sim}(19 \\
\mathrm{e} 16)\end{array}$ & 1984 & 1989 & 1995 \\
\hline \multicolumn{7}{|c|}{ Está casada desde 1990. Filhos nasceram em 1998 e 2001.} \\
\hline
\end{tabular}




\begin{tabular}{|l|c|c|c|c|c|c|}
\hline Stephanie & 57 & Divorciada & Não & 1981 & 1984 & 1988 \\
\hline \multicolumn{6}{|c|}{ Foi casada de 1983 a 1997.} \\
\hline
\end{tabular}

Quadro 7: Caracterização das entrevistadas em relação à idade, estado civil e ano de titulação.

\subsection{Entrevistada Alice}

No antigo Colegial (atual Ensino Médio), podia-se escolher entre Clássico e Científico. O Clássico era composto apenas por disciplinas do campo das Ciências Humanas, enquanto o Científico centrava-se em disciplinas das Ciências da Natureza e Exatas. Alice escolheu o Científico, teve um professor de Química muito bom e, assim, foi direcionando sua escolha profissional.

Da mesma maneira, durante o curso de Química, apaixonou-se pelas aulas de Bioquímica e escolheu a área para o Doutorado e sua atuação. Alice sempre trabalhou muito e dedicou-se integralmente à carreira.

A grande maioria se mata de trabalhar. Quer fazer um bom trabalho, quer publicar na melhor revista internacional. E fica uma coisa que não tem nada a ver com a forma de pensar para a cultura local. Eu quase nunca tirei férias, sempre trabalhei até tarde. Agora não. Agora eu estou cansada. Mas na minha rotina normal, eu ficava muito até de madrugada. No Doutorado, eu virava a noite. [...] Tinham uns experimentos que tinha que fazer, ficava 36 horas, porque eu chegava de manhã e começava a preparar, quando chegava de noite eu ia fazer o experimento. Aí eu fazia a noite inteira. Era melhor, porque era um experimento que precisava de sossego, era bom. Aí, quando chegava de manhã, falava: "eu não vou embora agora, senão eu vou ficar trocando o dia pela noite". Então eu acabava ficando lá e só ia embora no final do dia. Mas eu gostava tanto [...] (ALICE).

Alice conta a história de uma das primeiras professoras titulares de seu Intituto e considera que houve falta de reconhecimento do trabalho dela, apesar de citar também a falta de interesse dela em ocupar cargos administrativos na universidade.

[...] nossa, como ela se dedicou. De uma forma marcante mesmo. Ela se dedicou muito à Química, ao Instituto, à pesquisa. E inclusive no túmulo dela, lá no cemitério, está escrito que ela, eu acho que talvez ela até tenha feito a opção de não ter filhos [...] por causa do trabalho. E ela estava tão velhinha.

[...] E eu não acho que aqui houve um reconhecimento por ela. Justamente porque ela também não foi atrás de cargo. Ela não foi atrás de cargos. E eu acho que o fato dela ser mulher está no contexto. Ninguém falou... você vê, até na política eles estão querendo forçar para ter mais mulheres na política. É a mesma coisa por aqui. As mulheres não têm tanto interesse. Em ter uma atuação política (ALICE). 
A narradora conta, mesmo salientando que acha que isso é uma questão que mudou daquele tempo para hoje em dia, que foi questionada pelo seu orientador sobre querer a vaga de docente, uma vez que tinha se casado. A análise de similitude foi feita a partir de seu relato, obtendo-se a árvore mostrada na Figura 2.

Quando eu fui falar com o [nome do orientador], [...] eu falei "eu quero saber quais são as minhas chances, porque se eu não tenho chance, eu vou pegar esse outro emprego". Ele disse: "ah, você gostaria de trabalhar aqui?", eu casei no Doutorado lá. "Ah, eu não achava que você queria, porque eu achava que você queria casar e ter filhos, e eu não pensei que você ia querer, porque aqui você sabe, quer dizer, você vê: ou a pessoa não é casada, ou ela não tem filho, ou ela é casada, tem filhos, mas não tem marido". Quer dizer: a visão dele era que não dava para ter uma família assim, funcionante, e ter um cargo [...] (ALICE).

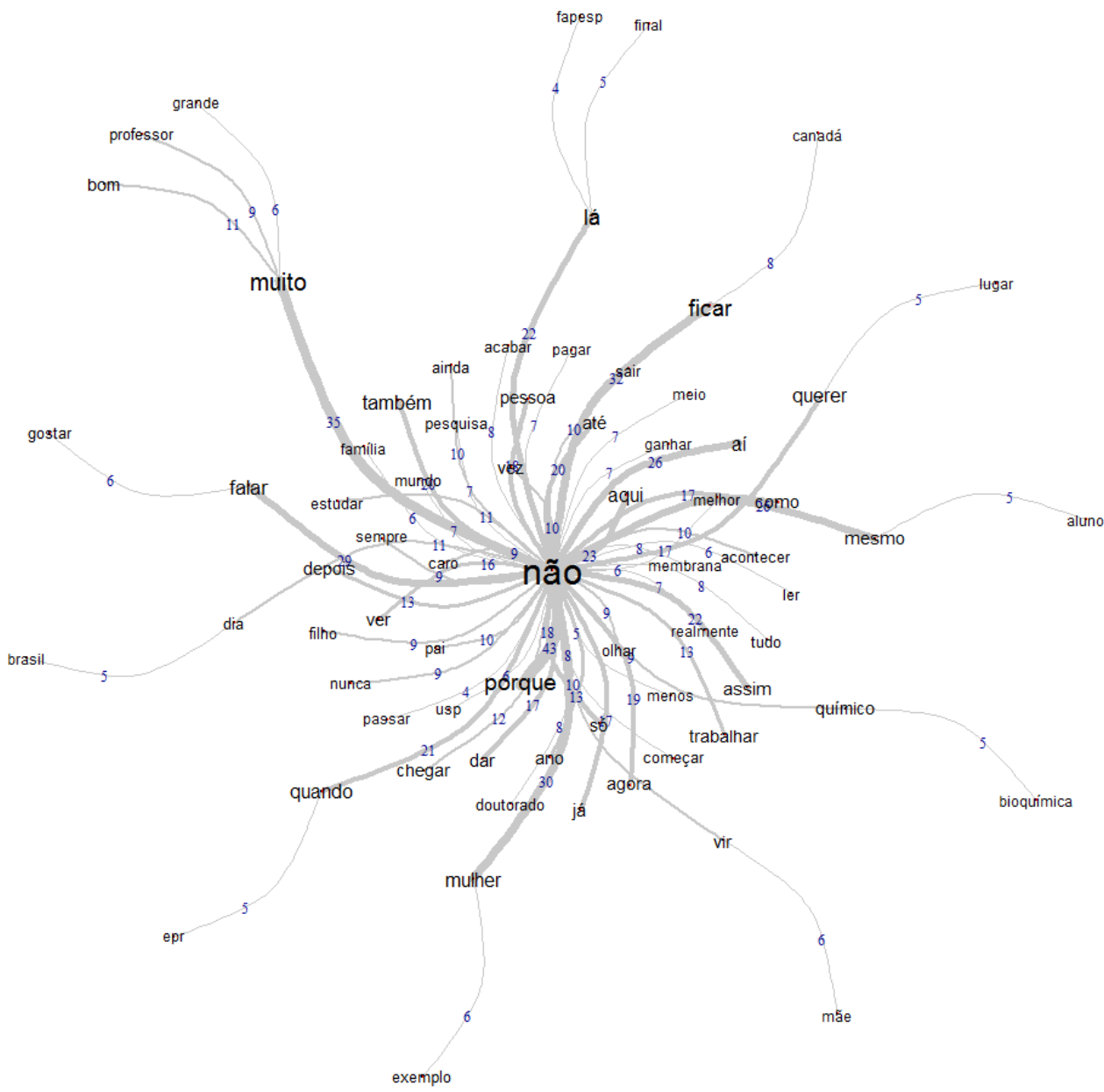

Figura 2: Árvore obtida a partir da análise de similitude do relato de Alice.

Nas árvores apresentadas, cada fio cinza conecta os pares de palavras citados no relato. O número que se encontra sobre o fio, que é chamado de aresta, refere-se à 
quantidade de vezes que o par de palavras aparece no relato. Quanto maior essa frequência, mais grossa a aresta e as palavras citadas têm maiores tamanhos e destaques. Os vértices ou as extremidades da árvore contêm as palavras menos citadas e com menos conexões, enquanto as que aparecem mais e relacionam-se mais vezes com outras palavras ficam no centro em maior evidência. Neste caso e em todos os próximos, pode-se observar a presença da palavra "não", sempre em maior destaque, relacionando-se às demais. Além disso, o par de palavras "não" e "mulher" aparece com grande destaque em todas as representações. Falaremos mais sobre isso adiante.

É importante salientar que os resultados obtidos neste trabalho foram comparados a resultados de outras pesquisas que utilizaram a mesma metodologia. Para se obter uma árvore mais "limpa", de forma que seja possível enxergar as conexões principais, é essencial omitir as palavras com menor frequência ao montá-la. Em muitos desses trabalhos consultados, a palavra "não" foi omitida por ser pouco citada e ter poucas conexões, o que não ocorre aqui.

\subsection{Entrevistada Annie}

Annie é Professora Doutora na área de Matemática da universidade onde trabalha e sempre gostou da disciplina, desde os tempos de escola. Estudou em escola particular, aproximava-se das Exatas de maneira geral, especialmente da Matemática, e foi aluna de um professor que a apoiou em sua escolha pela carreira e a incentivou em seu desenvolvimento e sua criatividade, marcando positivamente sua trajetória.

Com engenheiros na família, pensou em ingressar em Engenharia Civil, até "descobrir" que poderia cursar Matemática Pura, opção até o momento desconhecida para ela. Recebeu apoio da família, já que a Engenharia Civil a colocaria em situações complicadas, segundo ela, por ser mulher, principalmente por haver trabalhos de campo em canteiros de obras. A família questionou sua escolha pela Matemática Pura no sentido de propor que ela seguisse uma carreira mais "aplicada", como Economia, por exemplo.

Praticamente durante todo o seu percurso, era a única mulher na sala de aula. Segundo a entrevistada, durante toda sua trajetória, houve diversas situações em que o fato de ser uma das poucas mulheres era uma questão, mas isso só passou a ser percebido muitos anos depois. Ela relata que, seguindo sua carreira acadêmica, sentia falta de "modelos", de representatividade dentro da área, já que havia pouquíssimas professoras titulares e Livredocentes mulheres naquele instituto. 
A partir da Pós-Graduação, ela relata algumas situações que a incomodaram muito, desde constrangimentos e situações ruins vividas no dia a dia ou na ida a eventos científicos, até reflexões recentes sobre situações em sala de aula como professora e também imaginando circunstâncias vividas pelas próprias alunas, já que há predominância de homens.

Depois teve [...] um evento onde havia 60 participantes e 3 mulheres, e eu era uma das 3. Lembro de um cara chegar e falar assim: "ah, como é que você se sente sendo uma das únicas 3 mulheres do evento?", "bom, depois dessa pergunta, um pouquinho pior" (ANNIE).

Em um momento muito importante da entrevista, Annie relatou que, às vezes, ao pensar em como deveria se vestir em eventos científicos, sentia que tinha que ser "menos mulher" para ser mais reconhecida em seu trabalho, ou seja, "mais matemática"; ou então "menos matemática" para ser "mais mulher". Ela relatou que era quase que uma opção a ser feita entre ser mulher ou matemática. A árvore obtida na análise de similitude está na Figura 3.

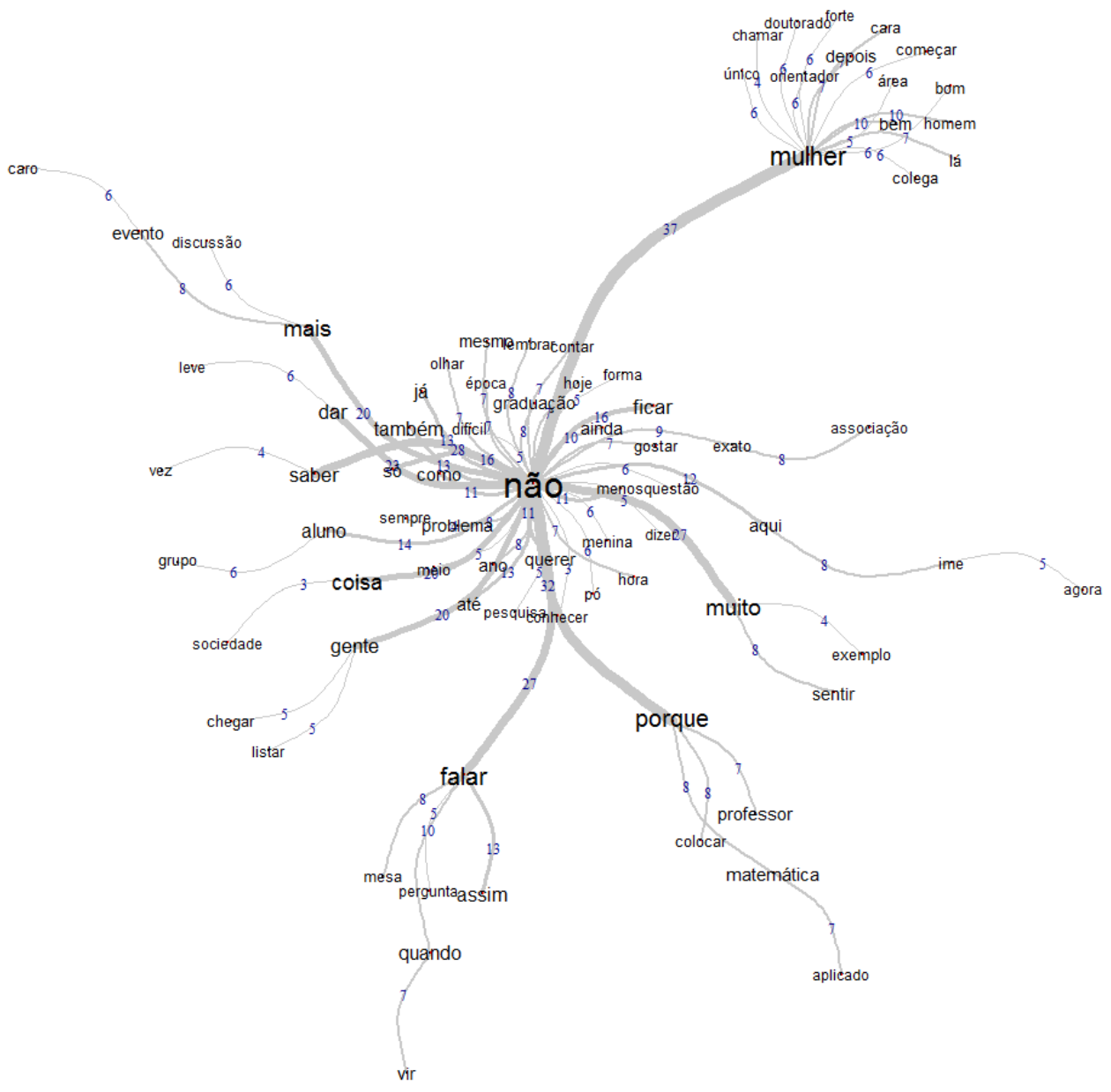

Figura 3: Árvore obtida a partir da análise de similitude do relato de Annie. 
Eu lembro que eu me sentia... eu me preocupava muito com que roupa eu ia vestir quando eu ia dar uma palestra em um evento, porque não podia nem ser feminina demais, nem de menos, sabe? Tinha que saber a dose certa, porque senão... Isso é uma coisa que eu acho muito forte... que ou você não é mulher, ou você não é uma matemática tão boa, entendeu? Ou você é feminina demais para ser um bom matemático, uma boa matemática, ou você é feminina de menos para ser mulher. Então é quase como se você estivesse fazendo uma opção entre ser matemática e ser mulher. Isso é bem forte, eu acho. [...]

Eu acho que durante a Graduação e Pós-Graduação tive um processo de desfeminilização na forma de me vestir, na forma de me comportar e que, depois, quando eu fui ganhando consciência sobre o problema e já era professora, fui recuperando isso (ANNIE).

\subsection{Entrevistada Enedina}

Enedina é da Bioquímica e, desde muito cedo, já se interessava pela área. No Ensino Fundamental teve um ótimo professor de Ciências, o que contribuiu para o fascínio pelo campo e a levou a um Ensino Médio técnico em Bioquímica. Sempre foi uma boa aluna, fez cursos no exterior e foi convidada a fazer Iniciação Científica.

Quando eu voltei para o Brasil, fiz uma pergunta em sala de aula que meu professor muito esperto de Bioquímica falou que ele só respondia no laboratório [...], porque ele achou minha pergunta boa e queria me mostrar o laboratório para me convencer a começar a trabalhar com ele. E eu fui trabalhar com ele, fiz Iniciação Científica com ele em todos os meus anos de faculdade, do primeiro ao sexto.

Sempre houve muito incentivo da família, pois os pais de Enedina são cientistas também, pesquisadores e professores universitários, então não considera ter tido grandes problemas no momento da escolha da carreira, pelo contrário, sempre teve apoio. Quanto a diferenças de gênero, disse não sentir essa questão.

Agora, eu nunca senti qualquer preconceito em relação ao meu gênero na minha carreira científica, nunca presenciei. A minha turma de colégio, é até engraçado, eram quase todas meninas. Em Bioquímica [modalidade de curso de auxiliar de técnico na época da lei 5692], não sei por quê. Minha turma de faculdade era meio a meio, no meu pós-doc eu era a única mulher no laboratório, mas era um laboratório pequeno também (ENEDINA).

$\mathrm{Na}$ opinião de Enedina, há mais mulheres na Bioquímica por ser uma área que possui mulheres cientistas visíveis na mídia. A análise de similitude de seu relato está mostrada na Figura 4.

Acho que outro motivo é que existem muitos modelos [...]. Então, você tem Mayana Zatz, Suzana Herculano, Lygia da Veiga Pereira direto na televisão 
"ó, eu sou cientista", e as meninas vão olhar isso e falar "ah, eu quero ser cientista também".

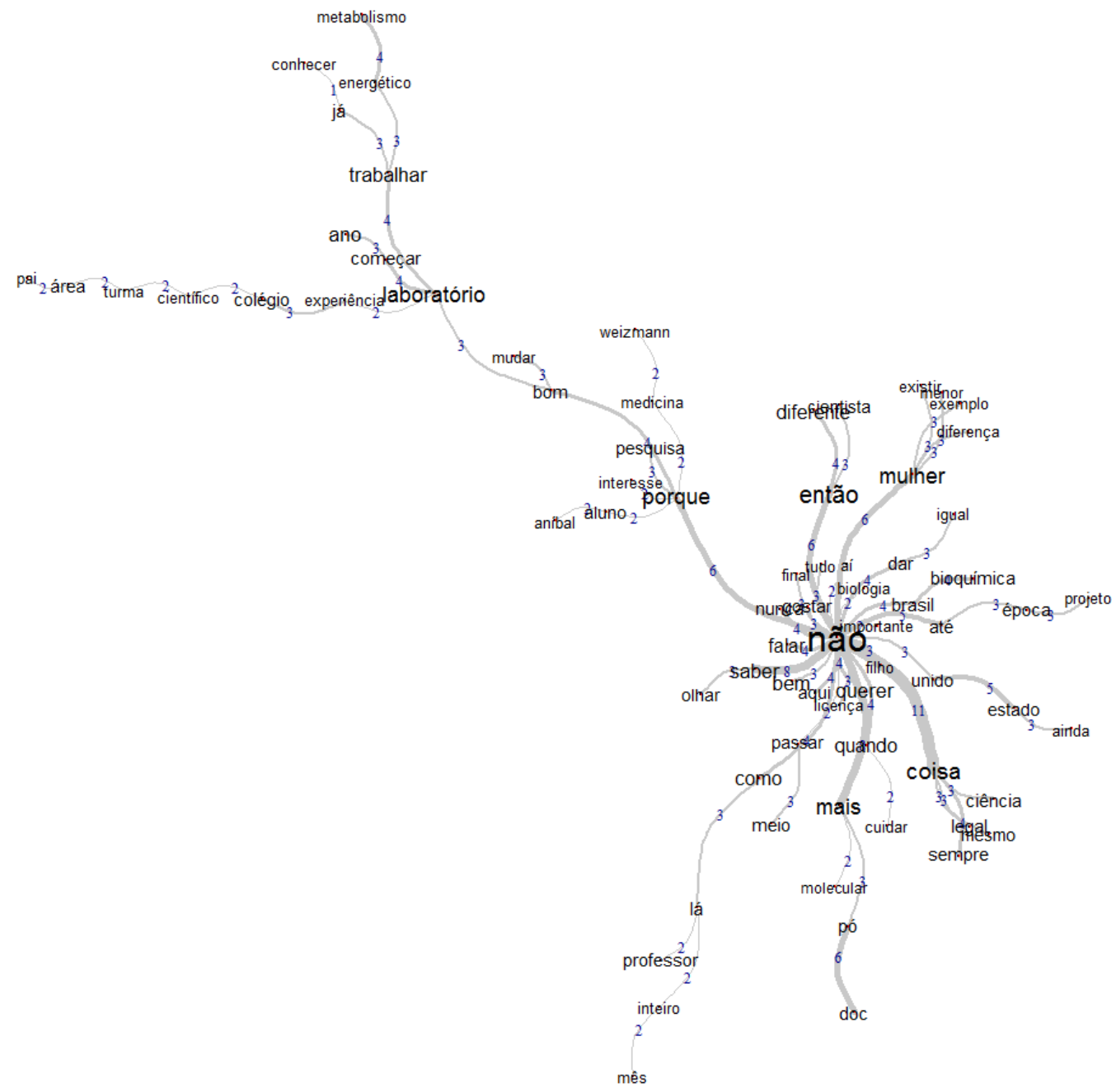

Figura 4: Árvore obtida a partir da análise de similitude do relato de Enedina.

\subsection{Entrevistada Grace}

Grace é formada em Biologia e trabalha atualmente na área de Bioquímica. É Professora Doutora em sua universidade e, desde a infância, interessava-se mais pelas áreas das Ciências da Natureza do que pelas outras disciplinas: ela relata que pode ser um interesse que venha do professor, mas que não sabe o exato motivo pelo qual foi atraída por essas áreas. 
Ao longo de toda sua Graduação, não sabia exatamente que área seguiria, aproveitava a faculdade mais como lazer, estudava apenas o necessário para passar nas disciplinas e não chegou a fazer Iniciação Científica ou estágio. Mas seu interesse pela Bioquímica surgiu bem cedo, apesar da pouca motivação acadêmica.

No decorrer do curso, eu realmente percebi que o meu interesse eram as
coisas moleculares. Que não tinha jeito, eu gostava de Bioquímica, eu
gostei muito de Genética. Eu nem tive Biologia Molecular, porque naquela
época não era consolidado como uma disciplina, eram umas coisas
pinceladas. Então a gente tinha um pouquinho de Genética Molecular,
gostei muito (GRACE).

A família sempre apoiou suas decisões e, segundo ela, mesmo a Biologia sendo sua escolha, área que, nas palavras da entrevistada, "não dá muito futuro", a família nunca foi contra isso. No entanto, algumas pessoas da família estranharam a carreira acadêmica, questionando "se ela nunca trabalharia, se só ficaria na faculdade".

Tinha uma parte da minha família mais distante, que depois de tantos anos na faculdade, "nunca sai da faculdade", "nunca sai da faculdade", fica com aquela coisa: "Mas essa menina não vai trabalhar nunca?". "Então essa menina nunca trabalhou". Havia isso, mas isso era mais "tiração de sarro". Mas em relação aos meus pais não, eles sempre me apoiaram muito (GRACE).

Devido à ausência de experiência em laboratório, ela procurou estágios antes de ingressar no Mestrado. Depois, todo o seu Mestrado e Doutorado, na área de Bioquímica, mais especificamente em Biologia Molecular, foi abrindo portas para seus outros trabalhos, pós-doutorado no exterior e outras atividades. Acabou conseguindo emprego em uma universidade do exterior, onde ficou por anos até voltar para o Brasil em um concurso. Ela cita algumas vezes o "choque" de línguas ao se mudar de país, tanto na ida, quando saiu do Brasil, quanto na volta.

E você chega já se achando meio burrinha, porque você é brasileira, a gente se sente assim. Na primeira reunião do laboratório, você entra no lugar e eles começam a falar aquelas coisas [...] em inglês, você sai tonta. Então, o primeiro mês foi muito difícil. [...]

E foi um grande trabalho, de verdade, porque eu tive que escrever projeto, escrever um memorial, e eu praticamente não falava mais português. Quer dizer, falar, falava. Falava em casa, falava com minha mãe, falava com meu filho, falava com as pessoas quando eu tinha que falar, mas eu não pensava mais em português, eu não escrevia em português, então eu tive muita dificuldade, nesse tempo, para organizar as coisas todas e vir fazer o concurso. E, na verdade, eu fiquei muito surpresa quando eu passei (GRACE).

Durante sua trajetória, a narradora relata ter escutado que era "muito bonitinha para fazer Ciência" ou que se enfeita muito para trabalhar na área.

A gente era da mesma turma de laboratório, a gente estava em laboratório distintos. Ela me disse que escutou no corredor um docente do 
departamento falando o seguinte: "Ah, mas essas duas aí", eu e ela, "Essas duas não vão dar certo, elas são muito bonitinhas para fazer Ciência". Eu não sei quem era o docente e não quis saber no momento. Falei "também não me importa" (GRACE).

Também diz que sentia, mesmo de forma sutil, que precisava produzir um pouco a mais do que os homens precisavam produzir para que tivesse a mesma credibilidade em seu trabalho (Figura 5).

É como se a gente, de fato, sempre tivesse que ser um pouquinho mais competente para chegar no mesmo lugar. Em alguns lugares é quase subliminar, mas sempre tem. Sempre tem. Você sempre tem que fazer um pouquinho a mais. E é como se fosse... demorar mais para você se estabelecer, para você se transformar em alguém aceito. Você precisa fazer mais para ganhar a mesma credibilidade que um homem ganha com um pouquinho menos de esforço (GRACE).

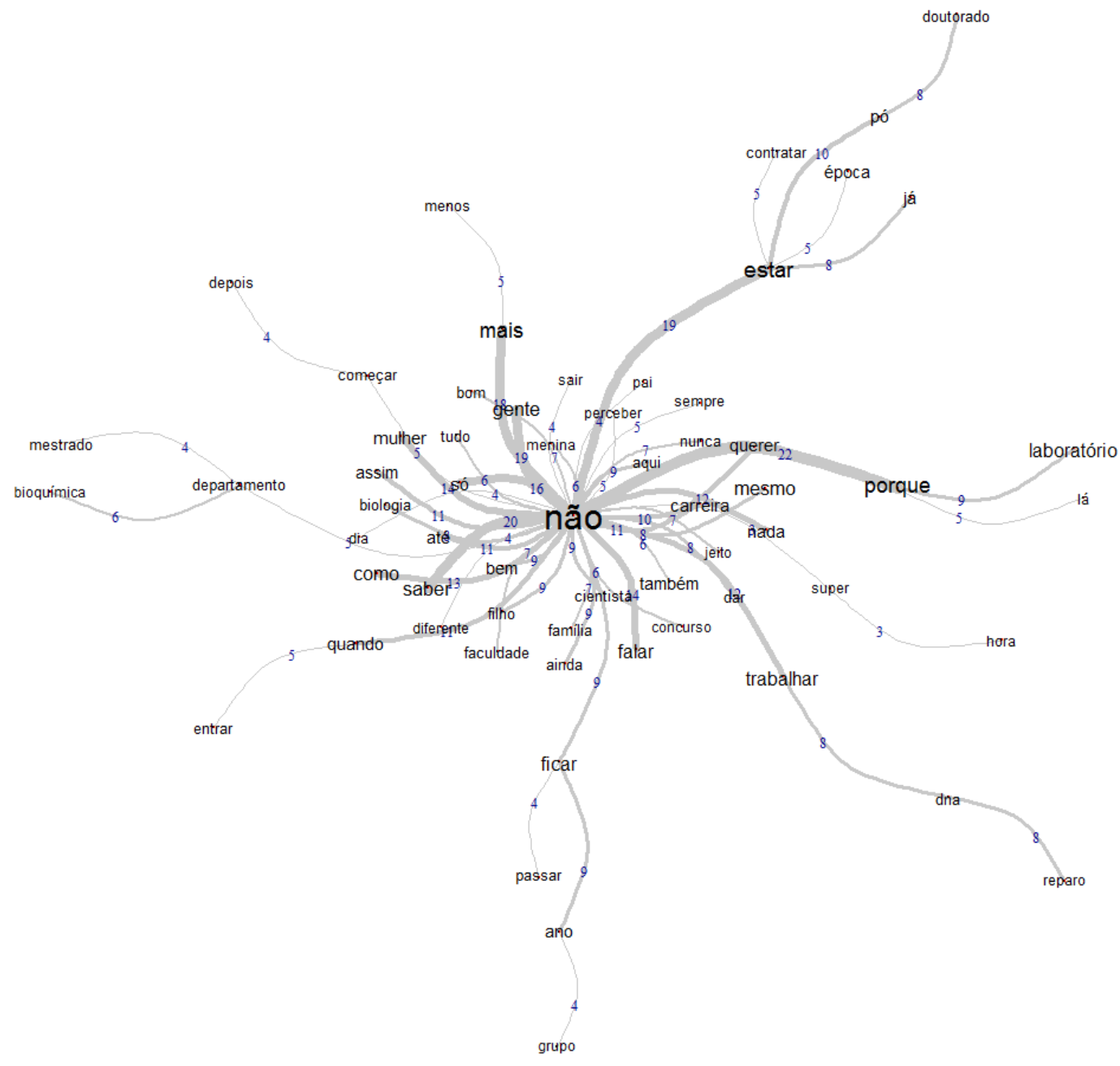

Figura 5: Árvore obtida a partir da análise de similitude do relato de Grace. 


\subsection{Entrevistada Juliana}

Juliana trabalhou desde cedo ajudando sua mãe com serviços de "office-boy", profissão que já se espera ser exercida por homens, como diz o próprio nome em inglês. Depois trabalhou como professora, monitora, estagiária, entre outros trabalhos, enquanto cursava Matemática.

A narradora seguiu para a Graduação em Matemática e, posteriormente, para a PósGraduação na Matemática Pura de forma quase que intuitiva. Ela relata que nunca pensou muito sobre qual carreira seguiria, apenas sentia que era o que deveria fazer e fazia. Foi feita análise de similitude do relato de Juliana e obteve-se a árvore mostrada na Figura 6.

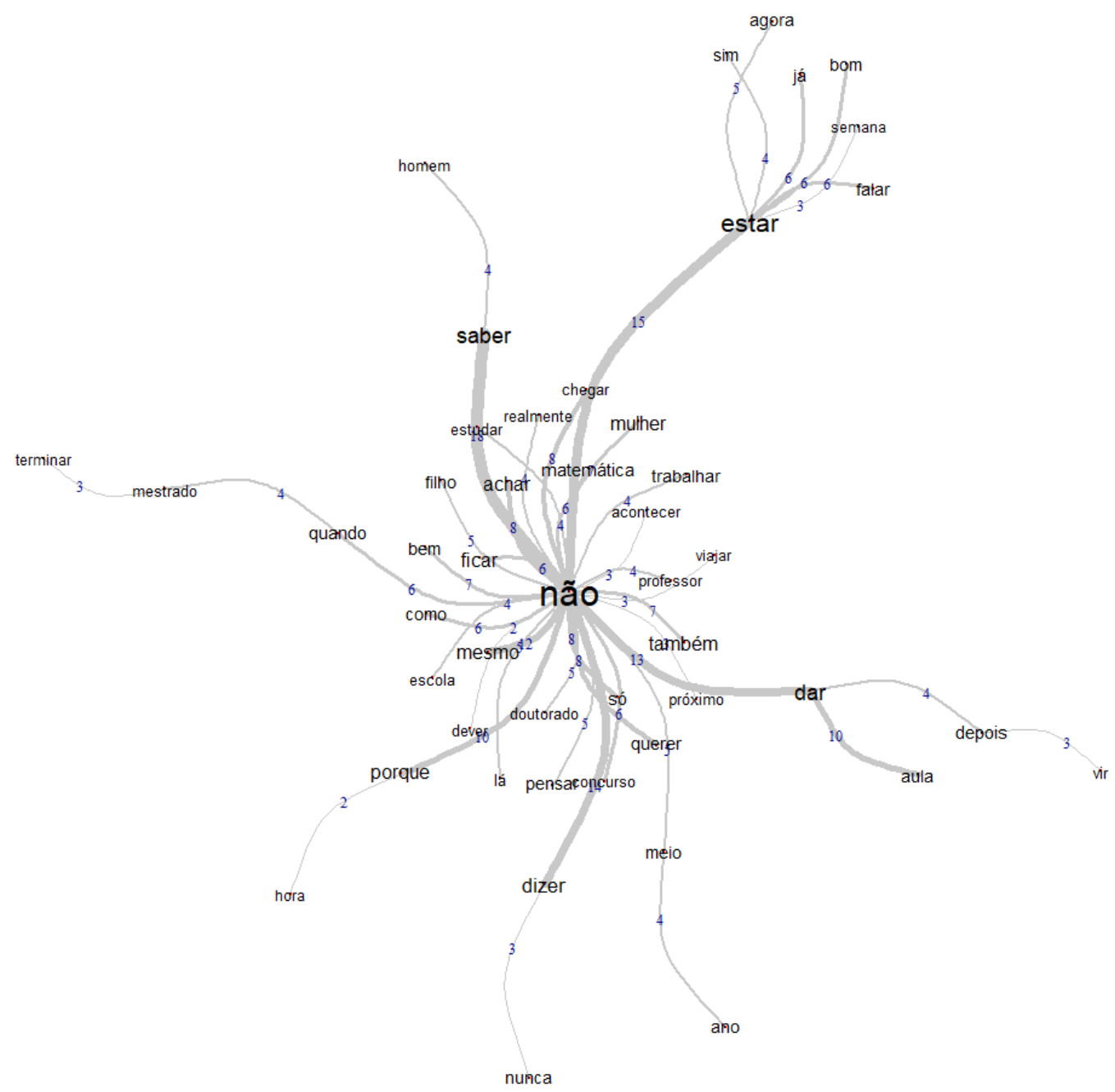

Figura 6: Árvore obtida a partir da análise de similitude do relato de Juliana. 
Eu nunca tinha pensado em fazer carreira acadêmica, sabe essa coisa de "puxa, você tem que sentar e fazer" não era um negócio que eu pensava, que eu sabia sequer como era, simplesmente foi acontecendo. Na época, foi acontecendo mesmo (JULIANA).

Juliana conta que a vontade de ser professora apareceu antes da de fazer Matemática, e sua família, de maneira geral, sempre a apoiou muito, pois para eles o importante era ter um diploma, já que eles não tiveram a mesma oportunidade. Alguns parentes questionavam sua escolha profissional no sentido de desconsiderar a Matemática uma carreira.

Acho que pensaram que Matemática não é profissão. Se fosse para ser professora, que eu fosse ser professora de Letras. Mulher fazer Letras pode, se não, se é para ter profissão, você tem que ter profissão: é advogado, médico, dentista ou engenheiro - profissão (JULIANA).

Juliana conta que apesar de ter se dedicado muito à carreira, também teve papel importante em sua vida pessoal cuidando dos filhos que nasceram durante o Mestrado e o Doutorado.

Eu realmente trabalhei muito, mas eu também cuidei muito de filho, e quando a gente cuida muito de filho não dá tempo de fazer tanta pesquisa quanto a gente quer, não tem jeito, não tem jeito, não adianta, que mulher que cuida de filho, que leva e traz, que faz e acontece, que leva no médico, então enquanto essa estrutura continuar sendo essa... E carreira acadêmica é um negócio muito absorvente, absorve muito, muito (JULIANA).

A entrevistada também diz que algumas vezes percebeu que o trabalho menos intelectual era dado às mulheres.

E tem um cara que gosta de pôr você para fazer coisas, por exemplo, se você está dando aula em uma equipe, as mulheres acabam fazendo mais serviço de "ah, você vai digitar a lista". Então, o trabalho braçal é muito dado às mulheres em uma equipe. Não todas as equipes, é claro, mesmo quando a coordenadora é mulher, acaba sobrando "ah, você vai digitar isso, você vai corrigir, vai carregar as plantas, você..." (JULIANA).

\subsection{Entrevistada Nagwa}

Nagwa sempre gostou muito de Química e de Ciências quando criança. Ela conta que em uma aula sobre a dualidade partícula-onda, achou as Ciências fascinantes e, desde então, tornou-se questionadora, sempre buscando os motivos subjacentes a determinados fenômenos, lendo e estudando muito. Logo que ingressou na área de Química, desde cedo, já começou a dar aulas e, a partir de seu interesse pessoal, seguiu carreira nesse campo. 
[...] não tive contato algum aqui com a parte científica, não fiz nem Iniciação Cientifica, nada disso, mas sempre gostei de Ciências e eu gostava de Química, era tudo coisa fantasiosa quando criança, laboratório, alquimia, essas coisas. Então eu fiz Química Industrial, eu gostava de laboratório, até fiquei na dúvida entre Filosofia e Química, porque eu gostava muito de ler e por fim optei por Química, isso há um bom tempo atrás. Eu gostava de laboratório, é uma coisa de que eu sempre gostei bastante, e gosto de Química, gosto bastante de Química.

$\mathrm{Na}$ hora em que eu estava para me formar, não tinha feito estágio aqui e nem conhecia pesquisa e nada disso. Naquela época, você não tinha tanta informação em rede, não tinha nada disso, o seu conhecimento dependia de onde você cresceu e família, mas na minha família é tudo semianalfabeto, quer dizer, não tinha cientistas e não tinha nada, eu não tinha nem ideia do que era; só tinha uma atração por resolver problemas, de saber por que as coisas são assim e não são assado, mesmo nos experimentos do laboratório (NAGWA).

Da mesma maneira seguiu para a Pós-Graduação e, durante seus estudos para a prova de ingresso de Doutorado, começou a interessar-se pela Bioquímica, sua área de trabalho até hoje. Para Nagwa, um grande problema na carreira das mulheres cientistas é o entendimento delas próprias sobre seus papeis sociais e profissionais. Foi feita a análise de similitude de seu relato, obtendo-se a árvore mostrada na Figura 7.

O problema é que tem muito preconceito das próprias mulheres, isso eu acho que é uma coisa. Nos meetings, mesmo internacionais, quando você chega sempre acham que você é secretária. Se você vai ser speaker num meeting, você chega lá, a secretária olha para você, ela não te incorpora como uma speaker, é diferente. Vem um homem, é diferente o tratamento, vem com crachá e para você é diferente, você tem que falar três vezes a mesma coisa, então são coisas pequenas, eu não acho que é uma coisa clara, você sente assim nas entrelinhas (NAGWA).

[...] isso é um pouco social, por isso que eu falo que as mulheres são as piores nesse ponto, as mulheres são facilmente chefiadas por homens, é sempre um negócio um pouco tenso, eu acho.

[...] as mulheres são responsáveis, porque elas criam os filhos diferentes das filhas, começa por elas próprias, porque elas deveriam criar um pouco mais igual e não é assim no geral e isso eu percebo que permanece.

[...] eu acho que a mulher tem que perseverar, se ela quer aquilo, e ir contra; é lógico que, muitas vezes, ela tem que mostrar muito, mesmo que ela seja melhor, tem que ser muito melhor para ser considerada, isso aí é verdade e tem preconceito. Você emprega um funcionário e ele fica 6 meses de licença e você não tem outro funcionário, então melhor pegar homem, melhor funcionário homem do que mulher. Então, tem todas essas coisas que são complexas e que as mulheres no fim têm que enfrentar, quer queiram, quer não, biologicamente não tem jeito, ela tem que ter os filhos.

[...] mudou bastante, os homens participam muito mais, mas tem a coisa biológica, quem vai amamentar é você. Vai botar na barriga, gerar por nove meses, não deve ser muito agradável, não tem jeito. Aí também é um pouco de Biologia. Mas lógico, acho que os homens têm que participar mais (NAGWA). 


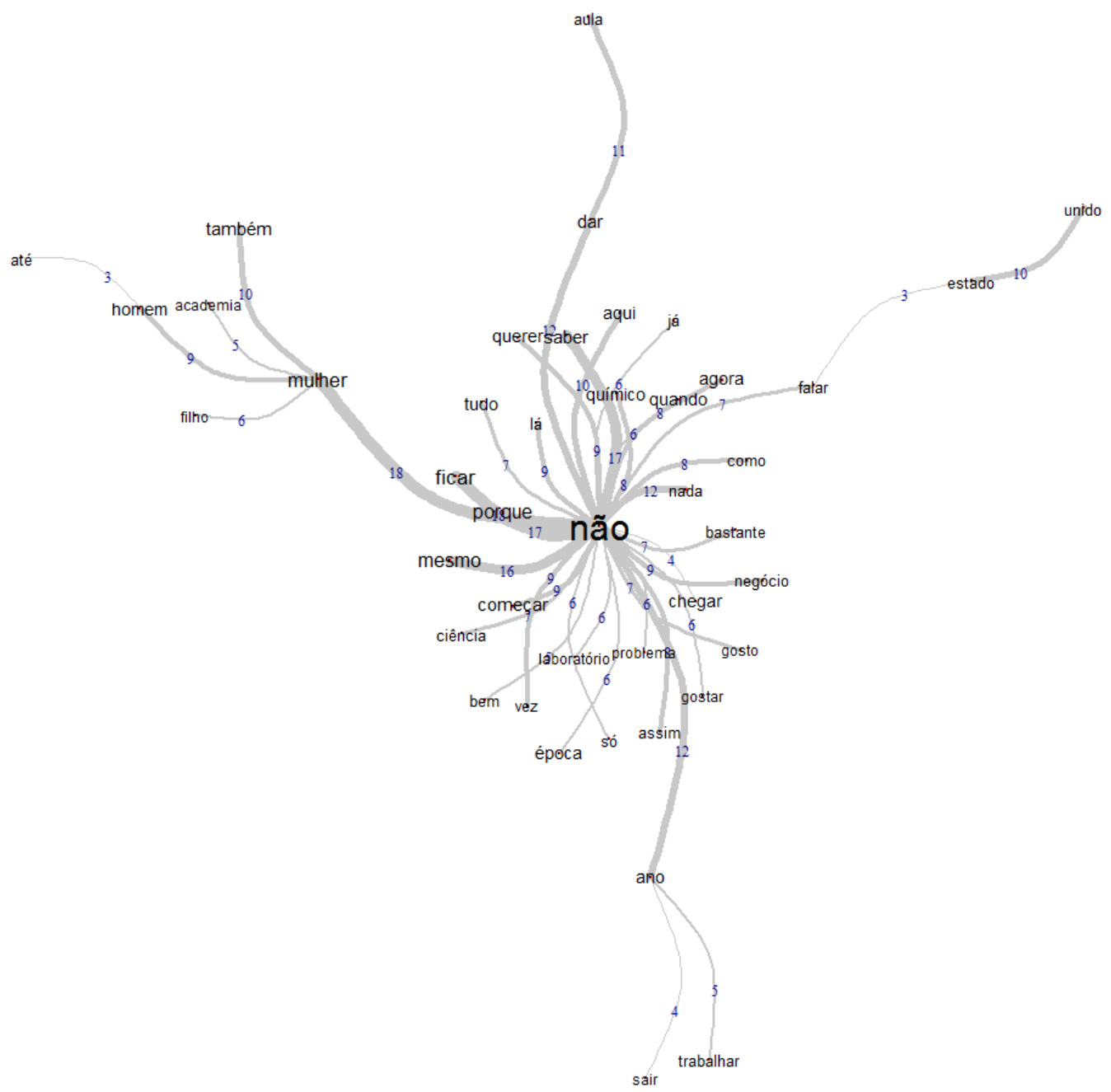

Figura 7: Árvore obtida a partir da análise de similitude do relato de Nagwa.

\subsection{Entrevistada Nise}

Nise é formada em Física e, atualmente, é Professora Doutora de uma universidade brasileira. Desde os 8 anos de idade já manifestava sua paixão pela Astronomia: adorava céu, estrelas e cometas, até mais tarde saber que esse campo era parte da Física. Muito antes da universidade, já frequentava o ambiente dela, já que sua escola técnica era dentro do campus universitário. Isso certamente permitiu um grande contato de Nise com a área acadêmica, o que a auxiliou em sua escolha profissional e a colocou em contato, desde 
muito cedo, com a universidade, já que durante todo o tempo em que ela esteve como estudante lá, dedicou-se a trabalhos dentro da própria universidade.

Além disso, Nise quis seguir carreira acadêmica por ter a sensação de ser um caminho praticamente obrigatório para quem está na Física. A análise de seu relato no IRAMUTEQ resultou no grafo apresentado na Figura 8.

Mas o Mestrado e o Doutorado eram uma coisa que eu pensava no sentido de que, quando você entra na Física, ou pelo menos quando a gente entrava lá, existia muito essa coisa de... na verdade, ainda existe... essa ideia de que você não é ninguém em Física só com uma Graduação. Enquanto em outras carreiras, se você faz uma Graduação em Engenharia, você tem uma profissão, você é engenheira, você faz coisas. Mas em Física, só a Graduação não conta muita coisa. Você não consegue, não tem muitas possibilidades, mesmo de mercado de trabalho, é muito reduzido (NISE).

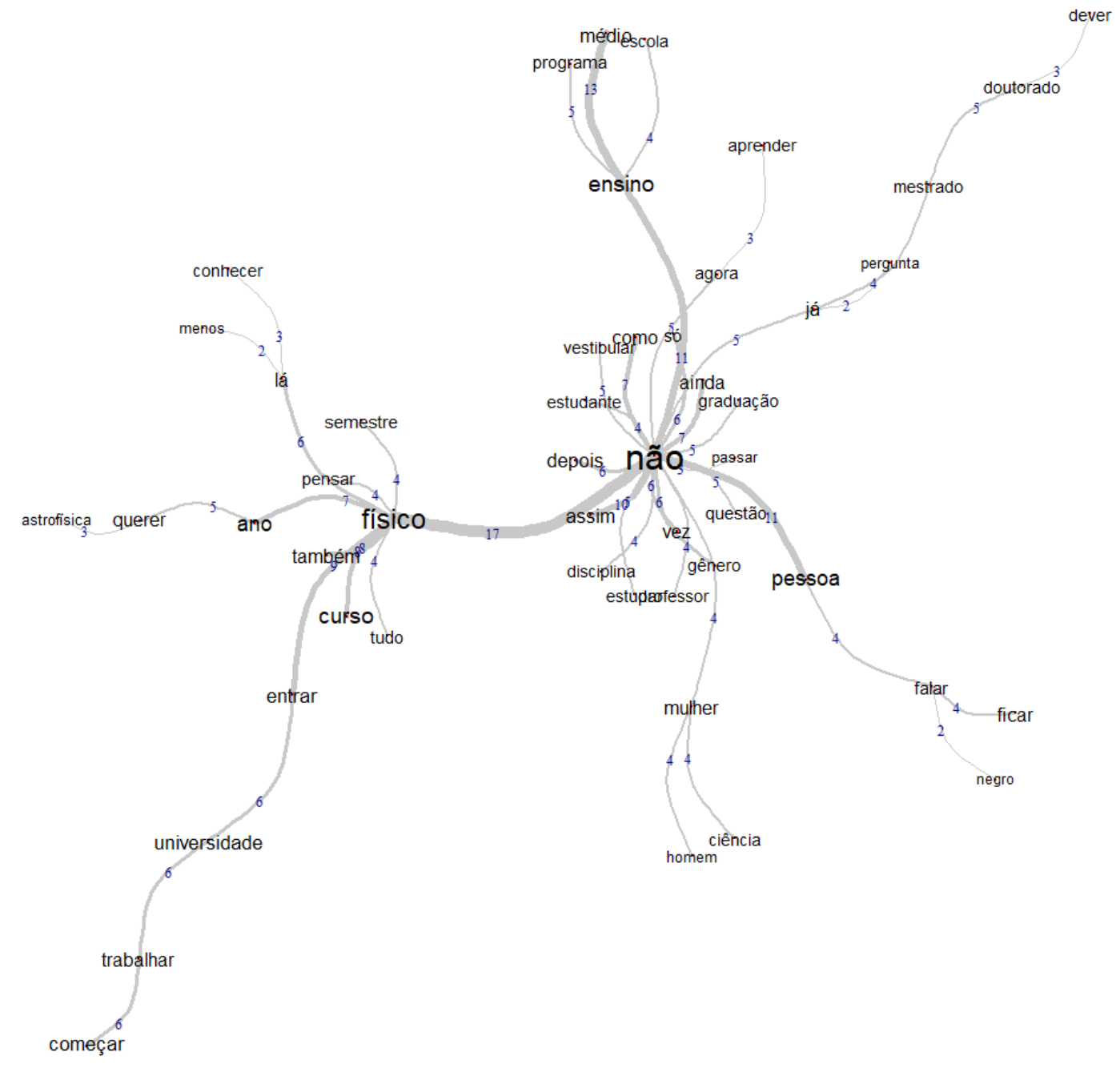

Figura 8: Árvore obtida a partir da análise de similitude do relato de Nise. 
Nise reconhece a questão de gênero nas Ciências da Natureza e Exatas e acredita que precisa haver uma conscientização do problema para que possamos avançar nessa discussão. Sua Pós-Graduação foi na área de História e Filosofia da Ciência.

Outra coisa também que pode contribuir, nesse mesmo sentido, são esses eventos, essas reuniões, esses encontros de mulheres cientistas. Eu acho que é necessário haver um trabalho de conscientização do que significa ser mulher na Ciência, porque nós temos ainda muitas mulheres na Ciência que não percebem que ser mulher na Ciência é diferente de ser homem na Ciência. E isso é um processo que só acontece através de conscientização, as pessoas têm que compreender que esses processos são engendrados e que é consciência, despertar da consciência. As pessoas têm que perceber que gênero é algo que influencia a carreira delas. Então a gente pode ver e escutar muitos discursos que colocam que não há diferenças, que nunca se sofreu preconceito, que não tem nada, mas isso a gente sabe que não é verdade. Não querendo tirar a autonomia da experiência que as pessoas têm. Não estou querendo desconsiderar as experiências que as pessoas têm, mas é uma questão de consciência sobre a experiência e é essa consciência que precisa ser adquirida. $E$ eu acho que esses eventos, esses espaços, podem contribuir para isso. A pessoa começa a enxergar que realmente há tratamentos diferenciados e há toda uma atmosfera que propicia que homens acabem indo melhor na carreira do que as mulheres. Então essa é uma coisa (NISE).

\subsection{Entrevistada Rosalind}

Rosalind sempre gostou mais das disciplinas de Exatas e acha que isso pode ter sido influenciado pelos bons professores que teve durante sua trajetória escolar. Ao longo da vida escolar, identificava-se mais com os meninos e, por isso, tinha mais amigos do que amigas.

E eu não gostava muito das meninas, as meninas eram muito fofoqueiras. Então, eu jogava bola com os meninos [...]. Eu estou falando sério, eu não gostava de andar com as meninas. Uma época cheguei até a passar esmalte, mas não gostava daquilo, cheguei à conclusão de que eu não gostava daquilo (ROSALIND).

Como a narradora tinha dois irmãos meninos, ela relata que desenvolveu essa identificação com os meninos também por causa disso e, ainda, criou maneiras de enfrentar os meninos com essa experiência. A análise de similitude feita a partir de seu relato está apresentada na Figura $\mathbf{9}$.

Eu tenho dois irmãos homens maiores e minha irmã. Eu sou a maior dos quatro. Então esse negócio de brigar com menino, eu já era craque. Os meninos são um pouco mais agressivos, eu acho que as meninas se fecham. Eu não, já estava acostumada com isso em casa, se menino viesse brigar comigo, tentava, porque eu já estava acostumada em casa, eu já nasci apanhando (ROSALIND). 
Rosalind cursou Engenharia Química antes de seguir carreira na Matemática e na Estatística, área que está até hoje. Ela acredita que essas identificações com meninos ou meninas têm relação com a forma com que se enfrentam situações do dia a dia.

Então eu ia brincar com os meninos, era mais moleca mesmo, de jogar bola, gostava de correr... como tinha os meus irmãos, também. lam todos lá, eu nem tinha boneca, minha mãe não comprava boneca, então brinquedo que tinha lá era igual para todo mundo, então a gente brincava muito de bola, brincava de carrinho, de bolinha de gude, andava de bicicleta.... é que naquela época, no interior, você brincava na rua, com os vizinhos de rua. Então, as minhas amigas não eram muito... eu não brincava só com meninas, eu brincava com meninas e meninos, da escola e da rua. Eu acho que isso ajuda a você entrar num ambiente predominantemente masculino e não se sentir... acho que ajuda você ter uma influência mais mista (ROSALIND).

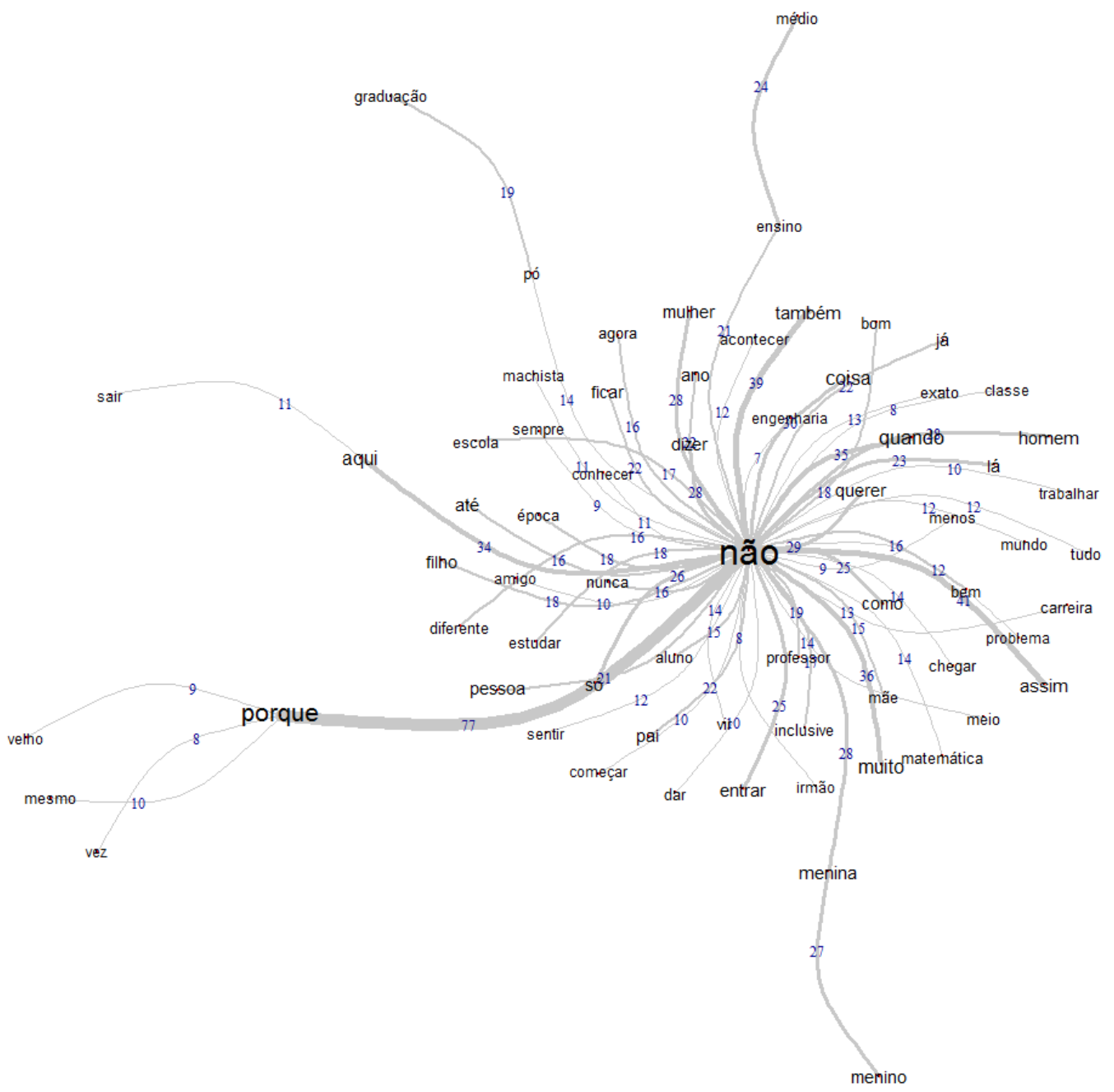

Figura 9: Árvore obtida a partir da análise de similitude do relato de Rosalind. 


\title{
6.11 Entrevistada Stephanie
}

Stephanie é formada em Física e professora titular em sua universidade. Ao longo de sua infância, seu contato com a área científica já era grande desde cedo, pois seu pai a convocava, junto com seus irmãos, para ajudá-lo a consertar objetos em casa, tarefa que a agradava mais do que aos irmãos e facilitou seu caminho para a Física.

Estudava em escola pública durante o dia e, à noite, trabalhava no laboratório do colégio montando kits de Química e Física. Quando entrou na Graduação, pela lista de ingresso eram oito alunas em um total de oitenta alunos. Entre essas oito, duas nunca ingressaram, de fato, e as outras cinco abandonaram o curso, de forma que a narradora se formou sozinha como única mulher naquele ano.

Então, foi aí que eu tive a clara percepção de que eu estava fazendo alguma coisa onde não tinha mulheres. Onde não se esperava que as mulheres assumissem posições de liderança (STEPHANIE).

Ela relata que, na época (final da Ditadura Militar no Brasil), praticamente todas as lideranças estudantis eram masculinas, não era só nas áreas das Ciências da Natureza e Exatas que havia tão poucas mulheres em papeis de liderança, o que a incomodava.

Stephanie concluiu a Graduação, seguiu carreira acadêmica, ingressou na PósGraduação como uma das poucas mulheres na área, fez Mestrado, Doutorado e PósDoutorado no exterior.

Durante sua trajetória, deparou-se com momentos em que seu papel como mulher cientista era questionado, não ouvido e não valorizado da maneira que esperava. $\mathrm{O}$ grafo obtido a partir da análise de similitude de seu relato está na Figura 10.

\begin{abstract}
Aí, você entra na carreira e o tempo todo é desafiada porque te confundem com a secretária, com a que está lá para distribuir brinde, a esposa de alguém, então ainda tem essas coisas que são desagradáveis. Você ainda é interrompida enquanto fala, tentam te explicar seu próprio trabalho, essa é mesmo uma delícia: quando tentam te explicar uma coisa que você fez; ignoram quando você dá opinião e, daqui a pouco, repetem o seu ponto de vista como se fosse criatividade deles, você enfrenta todo esse padrão, que ainda existe (STEPHANIE).
\end{abstract}

Ainda assim, continua sua carreira até hoje, pois tem força e "agressividade", característica que ela atribui no relato aos homens em um momento, e em outro, a si mesma.

Físicos são muito agressivos, usam qualquer instrumento para fazer sua ideia brilhar. Uma vez estava em um evento, em que nós tínhamos um debate importante sobre uma questão da nossa área e eu tinha uma opinião 
e um outro colega tinha uma outra opinião. Nós debatemos e obviamente a minha opinião terminou sendo a opinião que parecia a mais correta. $\mathrm{Na}$ saída, ele se virou para mim e disse que ele não conseguiu muito explanar a opinião que ele tem, porque o meu perfume o tinha atrapalhado. [...]

[...] É nesse momento [início da carreira docente] que as mulheres enfrentam, eu diria, a maior barreira, porque coincide esse momento com o momento em que as mulheres se tornam mães. $E$ que, na verdade, elas vão ter que compatibilizar tudo isso e o sistema não enxerga que, ao se tornar mãe, você não vai conseguir ter a mesma produtividade e isso faz com que as mulheres fiquem para trás. É medido nesse instante em que você tem que crescer e eu via como as mulheres iam ficando mais para trás e como você tinha que ser agressiva com seu dinheiro, financiamentos de estudantes, montar toda a sua estrutura. [...]

Olha, naturalmente eu sou uma pessoa bastante agressiva (STEPHANIE).

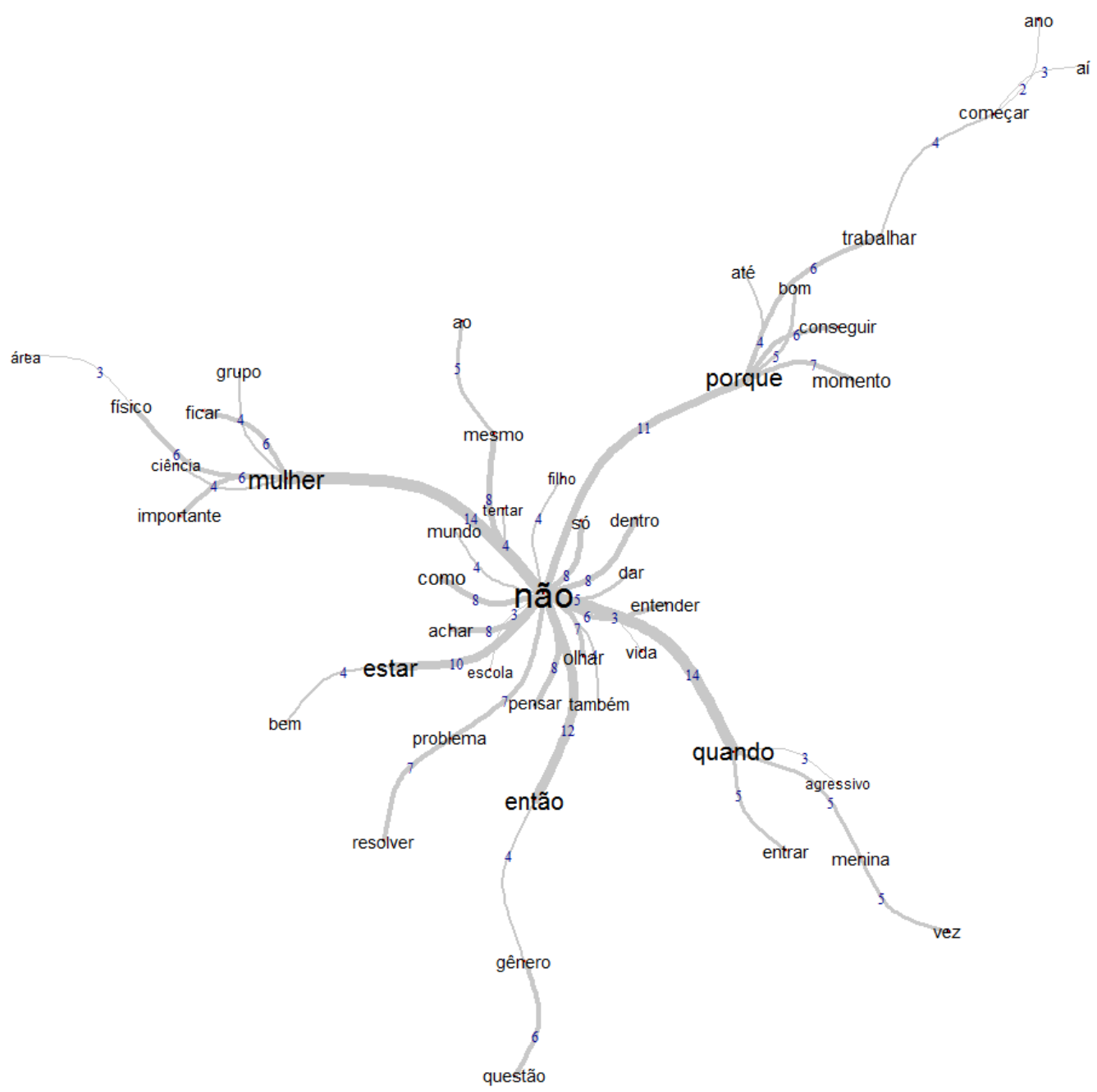

Figura 10: Árvore obtida a partir da análise de similitude do relato de Stephanie. 
Os nove relatos foram unidos em um único texto para fins de uma observação mais ampla e o texto final foi submetido à análise de similitude. O grafo obtido está apresentado na Figura 11 a seguir.

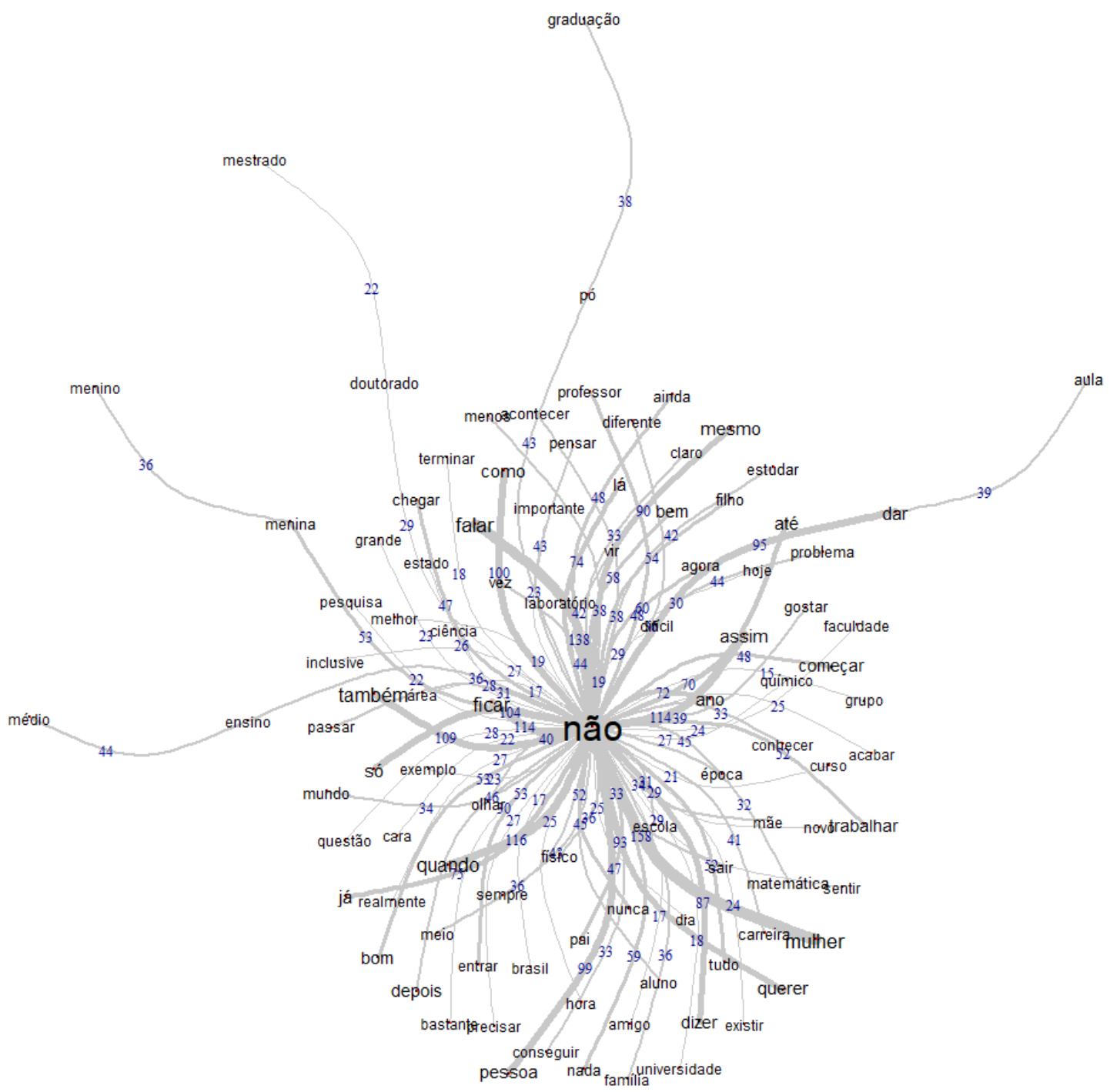

Figura 11: Árvore obtida a partir da análise de similitude de um único texto com todos os relatos.

\subsection{Discussão}

É importante notar que, em todos as entrevistas, destaca-se a negação de algo, sendo o "não" a palavra mais citada em todos os casos e, por isso, seu destaque é maior em todas as árvores obtidas. Nos excertos a seguir, as entrevistadas negam que sentiram ou sentem 
diferenças de gênero em suas carreiras científicas (Annie e Enedina), ou mesmo negam uma característica "das mulheres", de maneira geral (Nagwa).

Até então, eu comecei a sentir essas coisas, mas eu ainda achava que era uma coisa isolada, eu não me sentia muito intimidada... ou pelo menos não percebia em sala de aula. Mesmo em congresso, eu achava que era algo isolado. Tanto que quando eu conversei com as alunas [...], elas contaram que se sentem intimidadas nas aulas da graduação para fazer perguntas (ANNIE).

Eu acho que existe diferença de gênero, mas não existe prejuízo para a mulher. Eu acho que a gente é diferente, mas são curvas de Gauss também, as pontas podem ser completamente diferentes do meio, então existem diferenças entre as mulheres e entre os homens também (ENEDINA).

Acho que isso também tem um limite do que você vai conseguir tirar. O que tem que fazer é isso, compensar de alguma forma, esperar mais para subir na carreira ou coisas do tipo, porque por mais que o homem assuma essa parte, tem algumas coisas que as mulheres não gostam de fazer (NAGWA).

A negação é tema importante na Filosofia e está presente em diversos estudos psicanalíticos sobre o tema. Frege (1918-1919; 2002) ${ }^{27}$ apud D’Agord (2006) propõe que a negação é uma expressão discursiva de linguagem, não sendo expressão de conceitos autônomos.

Ele mostra que, se a negação não dá existência ou tira a existência de nada, ela deve ser concebida como discursiva. É ao tema da contradição a que Frege chega, como forma última de mostrar o funcionamento da negação no discurso: dados dois pensamentos, $A$ e a negação de $A$, sempre existe um, e somente um, que é verdadeiro. É, portanto, somente através do funcionamento discursivo oferecido pela negação (através da contradição) que seria possível atingir a verdade lógica (validade). [...] É na fala que é possível encontrar hesitações [...] (D’AGORD, 2006, p. 243).

Das concepções psicanalistas freudianas, há duas ideias sobre a negação: uma é a negação enquanto contrário de algo ou oposto e, a outra, como constituinte do que é negado. Em ambos os casos, a negação abre a possibilidade da afirmação, o que significa que não é por se ter algo negado, que se deve excluí-lo. Essa negação, segundo D’Agord (2006), é interessante para pensar o "não" se abrindo a novas significações.

Junqueira (2010), em seu trabalho sobre as práticas discursivas em relação à identidade de gênero e sexualidade nas escolas, apresenta duas possibilidades de análise da negação, uma elaborada a partir de estudos psicanalíticos e, outra, a partir de análises discursivas.

Pela precisão, é importante observar que Sigmund Freud utiliza dois termos para "negação". O primeiro [...], geralmente reservado para designar a recusa da percepção de um fato que se impõe no mundo exterior. $O$

27 FREGE, G. A negação: uma investigação lógica. In: Investigações lógicas. Porto Alegre: EDIPUCRS, 1918-1919/2002. 
segundo, [...] comumente traduzido como "denegação" ou "negativa", referese ao processo pelo qual o sujeito continua a defender-se de um desejo, pensamento ou sentimento [...]. A "recusa" é aparentemente mais deliberada, enquanto que nem sempre a "denegação" é percebida por quem a pratica. [...] Para os analistas do discurso, a noção de negação pode carregar certa ambiguidade e relacionar-se à interdiscursividade e a universos polifônicos de enunciação. Afinal, até mesmo uma negação descritiva pode não apenas "descrever um estado de coisas", mas também envolver contestação ou oposição a asserções anteriores (explícitas ou não) [...] (JUNQUEIRA, 2010, P. 126).

A palavra "não", que representa essa negação, está no centro dos grafos referentes às palavras mais citadas concomitantemente em cada uma das nove entrevistas realizadas e analisadas (Figuras 2 a 10). Nessa análise, é interessante observar o par que relaciona as palavras "não" e "mulher", que aparece sempre em grande destaque, algumas vezes como um dos três pares mais encontrados no relato. Como esses resultados surgem da análise de entrevistas livres, este pareamento do "não" ao "mulher" surge espontaneamente, não derivando de perguntas indutoras de qualquer espécie (tais como, "Você se sente mulher na área científica? Sim ou não?" ou "O que é ser mulher nas Ciências da Natureza e Exatas para você?").

Assim, o par de palavras "não" e "mulher" marca uma possível negação do "ser mulher" nessas carreiras científicas. Essa negação de si, mulher, é possivelmente a negação do que é construído por "feminilidade", "feminino" ou mesmo pelo "ser mulher" e o que se entende pelo "lugar de mulher" na sociedade. Michelle Perrot (1989, p. 12), ao discutir sobre o autoocultamento das vidas das mulheres, que contribui para o silenciamento que a sociedade impõe a elas, diz que o "consentimento da negação de si [...] está no âmago das educações femininas, sejam elas religiosas ou laicas".

É essencial destacar que essa possível negação da "feminilidade" não seria necessariamente uma negação da própria identidade (entendida dessa forma) ou uma mudança de identidade de gênero; trata-se, na verdade, de uma busca por reconhecimento em um "lugar" na sociedade diferente daquele estabelecido, preferencialmente similar ao ocupado por aqueles que estão em posições dominantes no que se refere aos privilégios advindos delas. Esse fato também é importante considerando-se qual lugar na sociedade é ocupado pelas mulheres, ou reconhecido por elas como tal. Ao se avaliar a hierarquia dos privilégios associada socialmente a esse lugar dito feminino, a procura por um lócus diferente, de reconhecimento e poder, também pode atravessar distintos espaços, como o de mulher negra nas Ciências da Natureza e Exatas: neste caso, a busca por um lugar dominante perpassa o ser-mulher e o ser-negra também. 
Bairros (1995) ${ }^{28}$ apud Ribeiro (2017, p. 70) diz que "de acordo com o ponto de vista feminista, portanto, não existe uma identidade, pois a experiência de ser mulher se dá de forma social e historicamente determinadas". Além disso, a compreensão de "ser mulher" decorre da perspectiva de cada mulher em um "lugar" na sociedade, mas existem outros; não se trata de uma "competição" de opressões, mas de perspectivas diferentes de mulheres diferentes que estão em outros "lugares" na sociedade.

Assim uma mulher negra trabalhadora não é triplamente oprimida ou mais oprimida do que uma mulher branca na mesma classe social, mas experimenta a opressão a partir de um lugar que proporciona um ponto de vista diferente sobre o que é ser mulher numa sociedade racista e sexista (BAIRROS, 1995, apud RIBEIRO, 2017, p. 70).

Ao se analisar a Figura 8, nota-se que, além da palavra "mulher", o "não" relaciona-se também à palavra "negro", quando a entrevistada é negra. Salientando que não necessariamente há nesse caso um desejo de "masculinização" estereotipada dessa e das outras mulheres entrevistadas, muito menos uma intenção de negação de sua própria negritude, o que pode haver é um anseio de reconhecimento de si, ou de seu trabalho, em outra perspectiva que não aquela que Ihe nega qualquer privilégio.

Annie, que é da área de Matemática, contou que, quando fazia apresentações e palestras e escolhia "ser feminina", seguindo padrões construídos socialmente como "femininos" - vestir determinadas roupas, enfeitar-se ou maquiar-se -, era como se escolhesse que dessem menos credibilidade ao seu trabalho; do contrário, se se vestisse de acordo com o que é construído socialmente como menos feminino, ou mais masculino, teria seu trabalho valorizado: "é quase como se você estivesse fazendo uma opção entre ser matemática e ser mulher" (Annie).

Annie contou que chamava a atenção o fato de ela ser mulher em um ambiente totalmente masculino, o que sempre a intimidava de alguma forma, seja por comentários dos colegas, seja pela forma que a tratavam.

Depois teve também um congresso, onde também houve alguns comentários, acho que mais de uma ocasião no Doutorado... essa coisa de que teve um evento onde havia 60 participantes e 3 mulheres, e eu era uma das 3. Lembro de um cara chegar e falar assim: "ah, como é que você se sente sendo uma das únicas 3 mulheres do evento?", "bom, depois dessa pergunta, um pouquinho pior" (ANNIE).

No relato de Grace, também é citada a ideia de não seguir, nas Ciências da Natureza e Exatas, o que a sociedade enxerga como "feminino".

E tem uma pressão até, de novo, que é uma coisa muito velada, para você não ser uma mulher muito arrumada. Eu não acho que eu sou uma mulher

28 BAIRROS, L. Nossos feminismos revisitados. In: RIBEIRO, Matilde (Org.). Revista Estudos Feministas, Dossiê Mulheres Negras, Florianópolis, v. 3, n. 3, 1995. 
muito arrumada, mas um monte de gente está o tempo inteiro falando, comentando coisas a respeito da minha aparência (GRACE).

Stephanie atribui em determinado momento do relato, como já foi apresentado, a agressividade como uma característica masculina, que ela diz que é muito presente na Física, sua área. Neste caso ela diz: "físicos são muito agressivos. Usam qualquer instrumento para fazer sua ideia brilhar" (STEPHANIE). Em outro momento do relato, ela atribui a si mesma essa característica: "naturalmente eu sou uma pessoa bastante agressiva" (STEPHANIE). Ela conta em seu relato sobre um momento em que o fato de ser mulher e cientista parecia "incompatível" aos olhos de seus colegas cientistas.

\begin{abstract}
Às vezes quando eu entrava em uma reunião em que ninguém me conhecia, aconteceu isso uma vez, foi muito engraçado; nota que eu consigo ver humor, porque eu vejo o aspecto social da coisa. Eu fui com o comitê, que era de um órgão internacional bastante importante e eram pessoas de diferentes áreas. $\mathrm{E}$ todo mundo foi contatado pelo sobrenome. Então eles não tinham noção de que tinha uma mulher no grupo e a gente combinou por e-mail "olha, vamos nos encontrar no lobby, no café da manhã do hotel. Um hotel minúsculo, provavelmente tinha só nós e mais umas pessoas, então vamos nos encontrar no café da manhã do hotel". Me sentei em uma mesa e fiquei esperando. Os outros chegavam e imediatamente se identificavam como iguais. Eram homens de meia idade, vamos dizer generosamente chamando pessoas de 60 anos de meia idade, barba branca, com estereótipo de cientista. Nenhum pensou que eu era cientista. Vendo até onde ia isso, as pessoas se juntavam e se dirigiam meio que em grupo até o local onde seria a reunião, que era em um prédio muito próximo, eu entrei depois. Quando eu entrei na sala, um deles se virou para mim e pediu para eu trazer cafezinho. Entende? Mas é porque para ele eu não podia ser cientista (STEPHANIE).
\end{abstract}

Rosalind contou também sobre como sempre se deu melhor com meninos do que com meninas em sua infância, e como isso contribuiu para a formação de sua personalidade mais incisiva, mais "agressiva" (característica que ela também atribui aos meninos em seu relato), menos quieta. Ela também cita um acessório entendido socialmente como típico de mulheres, que é o esmalte, para ilustrar sua repulsa pelo "ser menina".

E além disso eu gostava mais de brincar com os meninos do que com as meninas, as meninas realmente eram muito "titititi", sabe o que eu estou falando? Fala mal de uma, fala mal de outra, no outro dia está junto. [...] Eu não entendia as meninas, elas brigavam, elas choravam, elas xingavam uma a outra, uma semana depois estavam juntas de novo, falando mal de outras. Isso me deixava muito irritada. Eu não gostava. Eu estou falando sério, eu não gostava de andar com as meninas. Uma época cheguei até a passar esmalte, mas não gostava daquilo, cheguei à conclusão de que eu não gostava daquilo (ROSALIND).

Nagwa, em seu relato, cita um trabalho divulgado sobre uma mulher que recebeu a provocação de que deveria trabalhar "igual a um homem" e o quanto isso pode desestimular mulheres que não sentem que é possível serem diferentes do que são.

É, tem vários trabalhos sobre isso, até saiu um agora que deu escândalo, que ela recebeu a carta do referee falando que "era bom você trabalhar 
igual a um homem", ela botou no twitter e saiu em tudo quanto foi lugar. Os dados mostram, tem esse negócio, então [...] é lógico que se você não tem bastante energia ou bastante determinação ou é cabeça dura, chega uma hora que você está desestimulada e esse que é o ponto. Quer dizer, você fica batendo a cabeça contra a parede, lógico que chega uma hora que você vai falar "tchau", então isso tudo pode desestimular.

Foi evidenciada, também, a ideia do "feminino" associado à maternidade. É possível observar o "não" relacionado à palavra "filho" nas representações gráficas de alguns relatos, como da Alice, Enedina e Nagwa (Figuras 2, 4 e 7), três entrevistadas que não têm filhos, mas também em relatos de mulheres que têm filhos, como Juliana e Rosalind (Figuras 6 e 9), por exemplo, o que permite inferir essa ideia da negação não por fuga ou por mudança de identidade, mas pelo questionamento das posições ocupadas por elas na carreira, para além da biologia ou do corpo feminino.

E eu acho que tem essa coisa de ter filhos envolvidos, a carga sempre vai ser maior, você tem que dar esse desconto do filho. Então, se desconta seis meses ou um ano, eu não sei o número, mas isso vai acontecer (ENEDINA).

E também em termos de ser bem-sucedida na carreira, tem outro problema. Porque a gente está na carreira acadêmica, mas eu diria que em geral a gente não chega nos cargos mais elevados por causa de filhos, é diferente. [...] Uma coisa que o reitor falava: "as pessoas entram aqui, casam, têm filhos e aí diminuem [o ritmo de trabalho]". Aquilo foi um tapa na cara, principalmente das mulheres (ROSALIND).

Eu realmente trabalhei muito, mas eu também cuidei muito de filho, e quando a gente cuida muito de filho não dá tempo de fazer tanta pesquisa quanto a gente quer, não tem jeito, não tem jeito, não adianta, que mulher que cuida de filho, que leva e traz, que faz e acontece, que leva no médico (JULIANA).

Você emprega um funcionário e ele fica seis meses de licença e você não tem outro funcionário, então melhor pegar homem, melhor funcionário homem do que mulher. Então, tem todas essas coisas que são complexas e que as mulheres no fim têm que enfrentar, quer queira, quer não, biologicamente não tem jeito, ela tem que ter os filhos. [...] mas tem a coisa biológica, quem vai amamentar é você. Vai botar na barriga, gerar por nove meses, não deve ser muito agradável, não tem jeito (NAGWA).

Ela se dedicou muito à Química, ao Instituto, à pesquisa. E inclusive no túmulo dela, lá no cemitério, está escrito que ela, eu acho que talvez ela até tenha feito a opção de não ter filhos [...] por causa do trabalho (ALICE).

Dos nossos dados percebe-se que o lugar feminino é, a todo momento, questionado por violências simbólicas e isso mostra que o lugar da mulher no "feminino" construído socialmente pode ser inferido facilmente, mesmo que a partir de significados implícitos: se há cuidado com a família e se esta é posta como prioridade, a competência profissional pode ser colocada em dúvida; se não se dedica à família ou se não tem família, é uma mulher mal-amada, "encalhada", 'solteirona”, "masculina”. Invertendo-se os papeis, nota-se 
a diferença: os homens nessa segunda condição são estudiosos ou trabalhadores; e, na primeira condição, são super-heróis que conseguem fazer tudo.

Em síntese, os resultados do presente estudo mostram que, se não queremos, mulheres, ter o trabalho questionado, a competência posta em dúvida, a credibilidade em risco, qual o lugar que é possível ser necessário que se assuma? O de não-mulher.

Esses resultados corroboram aqueles encontrados na literatura que mostram que a atribuição e a consciência de características ditas "masculinas" em mulheres é muito comum em áreas profissionais como as Ciências da Natureza e Exatas. Maria Helena Fávero (2010) cita Davey $(2008)^{29}$ que, em um de seus trabalhos, fala sobre os procedimentos adotados por mulheres em suas identidades e carreiras e apresenta relatos de mulheres jovens em áreas tidas como masculinas como a Tecnologia da Informação e a Engenharia. Nas entrevistas, nenhuma questão de gênero era colocada de forma direta, mas as entrevistadas abordavam o tema espontaneamente, segundo a autora.

Nos resultados do estudo citado, os dados mostram que as participantes negavam sofrer discriminações de gênero e diziam ter construído suas carreiras com base em suas competências. Entretanto, é importante apontar que os dados também apresentam que essas mulheres desempenhavam funções e características construídas socialmente como "masculinas", como terem menos responsabilidades familiares e serem mais racionais. "Elas enfatizam a atividade política organizacional como uma forma de sociabilidade baseada na identidade e estilo de interação masculina e não feminina" (FÁVERO, 2010, p. 185).

Outro exemplo citado pela Fávero (2010) apresenta um trabalho de Besecke e Reilly $(2006)^{30}$ que enumera aspectos importantes sobre a questão de haver poucas mulheres em áreas profissionais em que há predominância de homens e conclui com algumas afirmações a respeito disso.

1. a existência de vieses de gênero e contextos discriminatórios no ensino de meninos e meninas e moças e rapazes no que se refere ao ensino de matemática e ciências de um modo geral, o que prejudica 0 desenvolvimento da autoconfiança e a escolha futura das meninas de carreiras relacionadas às ciências e tecnologias;

2. a existência de concepções estereotipadas na sociedade em geral, sobre o que seja ser cientista, tomado erroneamente como brilhantes e ao mesmo tempo socialmente incompetentes;

3. a importância de que todos os estudantes e particularmente as meninas tenham experiências positivas em relação à ciência e que tomem

29 DAVEY, K. M. Womens's accounts of organizational politcs as a gendering process. Gender, Work and Organization, v. 15, n. 6, p. 650-671, 2008.

30 BESECKE, L. M.; REILLY, A. H. Factors Influencing career Choice for Women in Science, Mathematics and Tecnology: The importance of a Transforming Experience. Advancing Women in Leadership Online Journal, v. 21, Summer, 2006. 
consciência dos estereótipos de gênero, sobretudo aqueles relacionados à dicotomia razão e emoção e de sua articulação com as escolhas profissionais (BESECKE; REILLY, 2006, apud FÁVERO, 2010, p. 189).

Essa atribuição do que é ser "feminino" e ser "masculino" relacionada às profissões é uma discussão que, segundo Michelle Perrot (2005), vem do prolongamento de funções ditas "naturais", maternais e domésticas, que constrói um modelo de mulher que é compatível com profissões como enfermeira, assistente social, professora primária, costureira, assistente etc. Essas funções são, na verdade,

Qualificações reais fantasiadas como "qualidades" naturais e subsumidas a um atributo supremo, a feminilidade: tais são os ingredientes da "profissão de mulher", construção e produto da relação entre os sexos (PERROT, 2005, p. 253).

Assim, codificar homens e mulheres em "pacotes" de características físicas fixas como se só existisse um tipo de mulher e um tipo de homem universal, leva as mulheres ao afastamento de profissões que elas pensam não se encaixarem, ou, se elas não se afastam, levam-nas a papeis diferentes daqueles esperados socialmente. Há, portanto, a "profissão de mulher" descrita por Perrot (2005), que é fruto de construções sociais, ou seja, pode ter diferentes configurações dependendo do tempo e do local histórico.

Enraizada no simbólico, no mental, na linguagem, o "ideal", a noção de "profissão de mulher" é uma construção social ligada à relação entre os sexos. Ela mostra as armadilhas da diferença, inocentada pela natureza, e erigida em princípio organizador, em uma relação desigual (PERROT, 2005, p. 258).

Essa relação desigual é alimentada cotidianamente no próprio ambiente de trabalho, por meio de violências muitas vezes não intencionais (FÁVERO, 2010), como mostrado em nosso trabalho. 


\section{Conclusões}

O objetivo central deste estudo, que era o de desvelar alguns dos fatores que conduzem as mulheres à desistência da carreira científica ou que sejam obstáculos para sua ascensão às posições de maior destaque nesse campo de trabalho, foi atingido. Este trabalho voltou-se a cientistas que já estão na carreira e têm relativa estabilidade nela, supondo que estas personagens possam ter desenvolvido mecanismos que as auxiliaram em seus percursos e em sua permanência e ascensão no campo. A hipótese norteadora do estudo desenvolvido é a de que a compreensão de seus percursos poderia elucidar quais fatores foram mais determinantes para o traçado da carreira destas professoras pesquisadoras. A partir dessa compreensão, é possível, também, refletir sobre como as meninas podem ser, desde cedo, incentivadas a gostar, ingressar e investir nessas áreas.

As entrevistas e análises que se sucederam, juntamente com o estudo da literatura, foram essenciais para que os primeiros três objetivos deste trabalho fossem contemplados: conhecer a história das mulheres na sociedade, na Educação e nas carreiras científicas; refletir sobre os papeis sociais construídos em nossa cultura e como eles também influenciam nas escolhas profissionais das mulheres e investigar mecanismos desenvolvidos por mulheres cientistas para permanência na carreira.

As vozes das mulheres entrevistadas protagonizaram o trabalho, que buscou conhecer a história delas, compreendendo também como se deram suas escolhas profissionais e quais os obstáculos que enfrentaram para permanecerem em seus campos profissionais, ainda que elas tenham diferentes graus de percepção quanto às questões de gênero subjacentes às suas escolhas. Além disso, a aproximação com estudos sobre a temática foi essencial para o conhecimento das histórias destas e de outras mulheres, além de ter contribuído para o conhecimento da condição das mulheres na sociedade em geral.

Foi interessante refletir sobre como os estereótipos de gênero são fortalecidos desde muito cedo na vida das crianças. Antes do nascimento, é comum o anseio pela descoberta do sexo do bebê: "É menino ou menina?" é uma pergunta que já carrega uma série de expectativas sobre como será o comportamento da criança que está por vir, expectativas que são praticamente universais. "É menino? Então vai adorar futebol" ou "É menina? Vai ser uma princesa" são falas comuns em nossa sociedade. Tende-se a padronizar, classificar, justificar, procurar semelhanças, de forma que tudo se torne mais compreensível e concreto no âmbito do que se conhece e, assim, aceito, quando as características mais valorizadas deveriam ser, justamente, a diversidade e a diferença. 
Nessas classificações, os estereótipos acabam moldando "lugares permitidos" para cada um de nós. O que se entende por "lugar de mulher" na sociedade abrange uma série de restrições, desde a forma de se vestir, falar e se comportar, até o que se espera dos desejos, da sexualidade, do corpo, das vontades, das profissões, dos cargos, da vida como um todo. Em nossa sociedade, o "lugar de mulher" é mais restrito do que o "lugar de homem". A exposição de meninos e meninas a um conjunto de atividades desde muito cedo, como os brinquedos - bonecas para as meninas e brinquedos mais estimulantes para os meninos -, ou as atividades que incentivam os meninos a se aventurarem mais do que as meninas, já esboça grande parte dos problemas que podem influenciar meninas a acreditarem que não teriam vocação para áreas como as Ciências Naturais e Exatas, por exemplo.

Quando as mulheres enfrentam todas as barreiras a que são submetidas e chegam a interessar-se e ingressar nas carreiras científicas associadas a esse campo do conhecimento, é preciso ultrapassar outros obstáculos, já que as pessoas que ocupam esses espaços também são sujeitas aos estereótipos dominantes socialmente e tiveram as suas oportunidades e vivências regidas por eles.

Muitas delas imaginam que precisam se "enquadrar" em um ambiente que, por definição, não pertenceria a elas. Dessa forma, quando nos resultados deste trabalho, se sobressai a ideia de "negar a feminilidade", na verdade, o que está evidente é esse "deslocamento para fora dos territórios que lhes foram reservados" explicado por Perrot (1989, p. 10). Ou seja, o comportamento fora do perfil "lido" como "feminino" é, na essência, uma forma de buscar maior credibilidade naquele lugar que elas ocupam, e materializa o desejo de reconhecimento naquela posição que seja igual ao atribuído aos homens.

Assim, muitas destas mulheres que ocupam campos predominantemente masculinos sentem que quanto mais "feminina" uma mulher - isso é, quanto mais normativa ela for no contexto do que se espera de seu comportamento, suas atitudes, sua aparência, seus gostos - menos apta ela está a um lugar que é histórica e culturalmente ocupado por homens. Quanto menos "feminina" for essa mulher, no sentido de se colocar nesse lugar de maior probabilidade de reconhecimento, mais possível será que ela ocupe esse lugar ainda que ao preço de ser identificada como aquela que não é "feminina", de fato, e ser criticada por isso. É importante dizer que, ainda que a liberdade dos homens para trabalho e estudos seja muito maior historicamente do que a das mulheres, quando eles estão em campos majoritariamente ocupados por mulheres (pelos mesmos estereótipos que as 
afastam das Ciências Exatas), também enfrentam preconceitos de outra ordem e questões muito similares, como por exemplo na Educação Infantil| ${ }^{31}$.

Outro objetivo do trabalho foi refletir sobre possibilidades de caminhos para o incentivo de meninas a ingressarem na carreira e o de mulheres a permanecerem nela. Um caminho para as mudanças começarem a acontecer, além do esforço para que os estereótipos já referidos sejam quebrados, é o da naturalização da presença de todas as mulheres em quaisquer espaços, inclusive os campos das Ciências Naturais e Exatas. É essencial não padronizar as características de todas as pessoas, não esperar determinados comportamentos para atribuir valor ao indivíduo, não pressupor opiniões e condutas, em outras palavras, valorizar a diferença. Uma história contada por Chimamanda Adichie (2015) retrata bem esse aspecto.

\begin{abstract}
Quando eu estava no primário, em Nsukka, uma cidade universitária no sudeste da Nigéria, no começo do ano letivo a professora anunciou que iria dar uma prova e quem tirasse a nota mais alta seria o monitor da classe. Ser monitor era muito importante. Ele podia anotar, diariamente, o nome dos colegas baderneiros, o que por si só já era ter um poder enorme; além disso, ele podia circular pela sala empunhando uma vara, patrulhando a turma do fundão. É claro que o monitor não podia usar a vara. Mas era uma ideia empolgante para uma criança de nove anos como eu. Eu queria muito ser a monitora da minha classe. E tirei a nota mais alta. Mas, para minha surpresa, a professora disse que o monitor seria um menino. Ela havia se esquecido de esclarecer esse ponto, achou que fosse óbvio. Um garoto tirou a segunda nota mais alta. Ele seria o monitor. O mais interessante é que o menino era uma alma bondosa e doce, que não tinha o menor interesse em vigiar a classe com uma vara. Que era exatamente o que eu almejava. Mas eu era menina e ele, menino, e ele foi escolhido (ADICHIE, 2015, p. 15).
\end{abstract}

A autora finaliza esse trecho com a ideia da representatividade, que é essencial na quebra de estereótipos. Caso os meios de comunicação, a escola, os livros falassem de mulheres cientistas contando suas histórias, as meninas teriam modelos de mulheres cientistas em que poderiam se espelhar e as chances de elas se interessarem por essas carreiras aumentariam.

Se repetirmos uma coisa várias vezes, ela se torna normal. Se vemos uma coisa com frequência, ela se torna normal. Se só os meninos são escolhidos como monitores da classe, então em algum momento nós todos vamos achar, mesmo que inconscientemente, que só um menino pode ser o monitor da classe. Se só os homens ocupam cargos de chefia nas empresas, começamos a achar "normal" que esses cargos de chefia só sejam ocupados por homens (ADICHIE, 2015, p. 16).

Para a construção de um conhecimento mais igualitário, é fundamental que todas as crianças sejam incentivadas a manifestarem seus desejos livremente e que tenham

31 Palhares, I. Homens ainda são minoria entre professores de creche e pré-escola. $\mathbf{O}$ Estado de $\mathbf{S}$. Paulo. Disponível em: <http://educacao.estadao.com.br/noticias/geral,homens-ainda-sao-minoriaentre-professores-de-creche-e-pre-escola,70001839941>. Acesso em: 17 dez. 2017. 
oportunidades de conhecer e gostar de brincadeiras variadas, temas diferentes, disciplinas diferentes, de exercitar comportamentos e atitudes diferentes, de experimentar cores, objetos e sensações variadas, sem delimitar o que é "permitido" ou não para cada uma delas. Esse ambiente mais igualitário acarretaria um leque maior de escolhas, as quais, inclusive profissionais, seriam mais livres, tanto para elas, quanto para seus colegas. Isso tornaria o futuro ambiente profissional delas mais acolhedor, menos taxativo e normativo e também as auxiliaria a não desistirem depois, por não sentirem que aquele seria seu lugar de pertença.

É importante, também, que sejam revistas as políticas de incentivo a todos/as os/as profissionais na carreira científica e acadêmica. Premiações para mulheres, políticas de permanência na carreira para mulheres, auxílio para pesquisadoras e pesquisadores poderem levar seus filhos a eventos, reconhecimento às mulheres na carreira, dentre outras iniciativas, auxiliariam também esse processo.

Considerando as limitações de um trabalho de pós-graduação, diante da complexidade das questões apresentadas, ansiou-se, em seu desenvolvimento, por oferecer uma contribuição ao estudo das questões de gênero, buscando suscitar reflexões acerca do que se pode, ainda, fazer para colaborar para a educação de crianças e jovens, a quebra de estereótipos e preconceitos, e para o incentivo de meninas ao ingresso, e de mulheres à permanência, no campo das Ciências da Natureza e Exatas. Estas ações podem contribuir para a construção de um mundo mais igualitário e, portanto, mais justo. 


\section{Considerações sobre a pesquisa}

A bibliografia sobre o tema ainda não é tão vasta assim: no Brasil, estudos de gênero nas Ciências da Natureza e Exatas são praticamente pioneiros. Assim, a obtenção de dados estatísticos foi bastante dificultada, no primeiro ano de desenvolvimento deste Mestrado (2015). A partir da metade de 2016, e ao longo de 2017, alguns orgãos de pesquisa dedicaram-se à produção de alguns dados que foram bastante relevantes para este trabalho; no entanto, fazem-se necessários, ainda, outros estudos estatísticos. Um exemplo é o de algumas universidades brasileiras não possuírem bancos de dados em que o número de discentes e docentes (Graduação e Pós-Graduação) seja apresentado em função do gênero. Como pensar em políticas de incentivo às mulheres para o ingresso na carreira científica sem esses dados oficiais?

Uma das reflexões iniciais neste trabalho foi sobre a visão que se tem de Ciência e, por consequência, de cientistas e até que ponto isso tem influência na escolha de estudantes por uma carreira futura. Para isso, foi realizado um estudo, em paralelo ao trabalho apresentado nesta Dissertação, com o objetivo de buscar alguns dos estereótipos que as crianças têm sobre cientistas.

O trabalho foi realizado em três salas de sexto ano de uma escola municipal de São Paulo durante um evento que estava sendo promovido nessa escola em que houve diversas atividades sobre questões de gênero, visibilidade e protagonismo das mulheres. O total de alunos participantes, somando as três turmas, foi de 63 crianças.

Primeiramente, apresentou-se a vida e a trajetória científica de Rosalind Franklin, primeira cientista a obter os dados necessários para a visualização de um modelo para a estrutura do DNA, uma das muitas mulheres praticamente excluídas e omitidas da história. Falou-se às crianças de seu gosto pelas Ciências, sobre como foi sua vida de cientista, contando tudo aos alunos sem mencionar seu gênero. Em seguida, pediu-se a eles que desenhassem essa pessoa como a imaginavam e que representassem suas características de acordo com a imagem que eles tinham sobre a profissão de cientista. Não foi fornecida qualquer pista sobre o gênero da pessoa cuja história estava sendo apresentada; buscou-se utilizar uma linguagem neutra, evitando artigos e identificando-a como "pessoa cientista" em tudo o que foi contado sobre Rosalind. Após os desenhos terem sido elaborados e entregues, foi feita uma breve apresentação final, esclarecendo que se tratava de Rosalind Franklin, seguida de uma exposição sobre outras mulheres cientistas importantes.

A grande maioria $(72 \%)$ dos alunos desenhou cientistas homens caracterizados por alguns estereótipos como jaleco, óculos, ambiente de laboratório ou fisionomia de "louco"; 
algumas crianças desenharam cientistas mulheres (19\%) e, outras, sem gênero definido (9\%). Há de se ressaltar que algumas das crianças que representaram cientistas homens, desenharam mulheres como assistentes deles (9\%).

Muitas crianças incluíram balões de fala que tentavam representar a visão que elas têm do contexto de muito estudo e trabalho, nos quais essas(es) cientistas estão incluídos, como "sou inteligente", "quero café", ou mesmo sinais de que se tratavam de ambientes que eles entendem como científicos, com vidrarias de laboratório, cálculos anotados e experimentos (os desenhos estão no Anexo 3, p. 104).

Apesar das várias atividades que estavam sendo desenvolvidas na escola durante o evento sobre questões de gênero, a grande maioria das crianças teve dificuldade de imaginar que pudesse existir uma mulher cientista. Boa parte das que representaram mulheres disse ter "desconfiado" que seria uma mulher, por conta do evento. Este resultado indica que a representação espontânea de uma mulher cientista poderia ser inferior aos $19 \%$ verificados neste estudo.

Em relação às entrevistas realizadas para este trabalho, embora apenas uma das nove mulheres entrevistadas seja negra e nenhuma delas seja transgênero ou transexual, buscamos, de alguma forma, pensar sobre todas as mulheres em todas as etapas deste trabalho, considerando-as em sua diversidade, com base em estatísticas e histórias de vida. A primeira mulher negra engenheira no Brasil foi Enedina Alves Marques (Anexo 2, p. 102), não à toa um dos nomes fictícios utilizados para designar uma das entrevistadas deste trabalho. Há pouquíssimos registros de mulheres cientistas trans; no Brasil, então, nem se fala. Mas Joan Roughgarden (Anexo 2, p. 102) é importantíssima, pois é uma cientista trans muito à frente de seu tempo, crítica das teorias de seleção sexual de Darwin.

Em sua palestra no TEDx ${ }^{32}$, Joan dá alguns exemplos de espécies de animais que não se encaixam nas definições de macho e fêmea amplamente conhecidas pela Biologia e que não são exceções, pelo contrário, são muito comuns, como alguns peixes que são intersexuais ou que "mudam de sexo" ao longo da vida. Ela também cita espécies que têm comportamentos não-normativos em relação à sexualidade - alguns animais são homossexuais e bissexuais -, e em relação a "papeis de gênero", que são diferentes daqueles que conhecemos - como machos que cuidam da prole enquanto as fêmeas caçam e acasalam com outros machos, por exemplo.

32 TEDx são conferências realizadas em diversos países do mundo, sem fins lucrativos, com a finalidade de disseminar ideias. As palestras são curtas e divulgadas em vídeos na internet. A referida palestra de Joan Roughgarden foi realizada em 2011 e está disponível em: <https://www.youtube.com/watch?v=KJ3lcCa0G4Y>. Acesso em: 08 dez. 2017. 
Comparando com o que evidenciamos neste estudo, é importante salientar que não existe um tipo de mulher universal. Então, quando se fala em pensar em políticas de incentivo ou em práticas sociais para "mulheres", está-se pensando em todas as mulheres, mas, atualmente, o espaço amostral estatístico referente a gênero inclui mais mulheres brancas, cis e de classes mais elevadas.

Propor entrevistas com mulheres cientistas foi muito importante, entre outros motivos, por ouvir a história de vida destas pessoas que estão em posições de sucesso, o que é essencial para protagonizar suas vozes como sujeitos principais de histórias de cientistas. Ainda, escrever todas as linhas deste trabalho na minha voz, também de mulher cientista, foi primordial para todo este percurso, que aqui se encerra, mesmo que por ora. Há de se concluir a escrita deste trabalho, mas não a luta nem o desejo de construir uma sociedade em que haja liberdade para todas as pessoas. 


\section{REFERÊNCIAS ${ }^{33}$}

ADICHIE, C. N. Sejamos todos feministas. Trad. Christina Baum. São Paulo: Companhia das Letras, 2015.

ÁVILA, R. C. Notas sobre a mulher contemporânea no ensino superior. Mal-Estar e Sociedade, ano II, n. 2. Barbacena, p. 91-106, 2009.

BARDIN, L. Análise de conteúdo. Trad. Luís Antero Reto e Augusto Pinheiro. Lisboa: Edições 70, 1977.

BEAUVOIR, S. As belas imagens. Trad. Lucila Ribeiro Bernardet. São Paulo: Difusão Europeia do Livro, 1966.

O segundo sexo. Trad. Sérgio Milliet. 2. ed. Rio de Janeiro: Nova Fronteira, 2009.

BOURDIEU, P. A dominação masculina. Trad. Maria Helena Kühner, 4 ed. Rio de Janeiro: BestBolso, 2017.

Os usos sociais da ciência: por uma sociologia clínica do campo científico. Trad. Denice Barbara Catani. São Paulo: Editora Unesp, 2004.

BRASIL. Instituto Brasileiro de Geografia e Estatística (IBGE), 2003 a 2013. Indicadores IBGE: Principais destaques da evolução do mercado de trabalho nas regiões metropolitanas abrangidas pela pesquisa. Disponível em: <http://www.ibge.gov.br/home/estatistica/indicadores/trabalhoerendimento/pme_nova/retrosp ectiva2003_2013.pdf>. Acesso em: 13 jul. 2017.

Instituto Nacional de Estudos e Pesquisas Educacionais Anísio Teixeira (INEP), Ministério da Educação (MEC), 2007. Censo do professor. Disponível em: <http://portal.mec.gov.br/plano-nacional-de-formacao-de-professores/censo-do-professor>. Acesso em: 07 jun. 2017.

Instituto Nacional de Estudos e Pesquisas Educacionais Anísio Teixeira (INEP), Ministério da Educação (MEC), 2009. Estudo exploratório sobre o professor brasileiro com base nos resultados do Censo Escolar da Educação Básica. Disponível em: $<$ http://download.inep.gov.br/download/censo/2009/Estudo_Professor_1.pdf>. Acesso em: 26 maio 2017.

Instituto Nacional de Estudos e Pesquisas Educacionais Anísio Teixeira (INEP), Ministério da Educação (MEC), 2012. Censo da Educação Superior. Disponível em: $<$ http://portal.mec.gov.br/index.php?option=com_docman\&view=download\&alias=14153coletiva-censo-superior-2012\&Itemid=30192>. Acesso em: 6 jun. 2017.

Conselho Nacional de Desenvolvimento Científico e Tecnológico, 2014. Bolsas no país: distribuição segundo grande área e sexo do bolsista. Disponível em: <http://cnpq.br/documents/10157/adb76b26-3a8a-4478-9605-e7325e9de50e>. Acesso em: 08 ago. 2016.

${ }^{33}$ Elaborada de acordo com as normas indicadas na ABNT NBR 6023, da Associação Brasileira de Normas Técnicas (ABNT). 
Centro de Gestão e Estudos Estratégicos (CGEE) e Ministério da Ciência, Tecnologia e Inovação (MCTI), 2015. Pesquisa sobre a Percepção Pública da Ciência e Tecnologia no Brasil. Disponível em: <http://percepcaocti.cgee.org.br>. Acesso em: 10 maio 2017.

\begin{tabular}{lllll}
\multicolumn{2}{c}{. Instituto Brasileiro de Geografia e Estatística (IBGE), 2016. Pesquisa Nacional por } \\
\hline Amostra & de & Domicílios & 2015. & Disponível em: e
\end{tabular} $<$ https://ww2.ibge.gov.br/home/estatistica/populacao/trabalhoerendimento/pnad2015/default. shtm>. Acesso em: 01 dez. 2017.

Instituto Brasileiro de Geografia e Estatística (IBGE), 2016. PNAD 2015: rendimentos têm queda e desigualdade mantém trajetória de redução. Agência IBGE Notícias. Disponível em: <https://agenciadenoticias.ibge.gov.br/agencia-noticias/2013agencia-de-noticias/releases/9461-pnad-2015-rendimentos-tem-queda-e-desigualdademantem-trajetoria-de-reducao.html>. Acesso em: 01 dez. 2017.

Instituto Brasileiro de Geografia e Estatística (IBGE), 2017. Tarefas domésticas impõem carga de trabalho maior para mulheres. Agência IBGE Notícias. Disponível em: e $<$ https://agenciadenoticias.ibge.gov.br/agencia-noticias/2012-agencia-de-

noticias/noticias/18568-tarefas-domesticas-impoem-carga-de-trabalho-maior-para-

mulheres.html>. Acesso em: 01 dez. 2017.

. Instituto de Pesquisa Econômica Aplicada (IPEA), 2017. Retrato das Desigualdades de Gênero e Raça - 20 anos. Disponível em: $<$ http://www.ipea.gov.br/portal/images/stories/PDFs/170306_apresentacao_retrato.pdf>. Acesso em: 07 set. 2017.

CAMPOS, H. de. A arte no horizonte do provável. São Paulo: Perspectiva, 1977.

CATANI, A. M. et al. Vocabulário Bourdieu. 1. ed. Belo Horizonte: Autêntica Editora, 2017.

CHASSOT, A. I. A Ciência é masculina? É sim, senhora! 7. ed. São Leopoldo: Editora Unisinos, 2015.

CECI, S. J.; WILLIAMS, W. M.; BARNETT, S. M. Women's Underrepresentation in Science: Sociocultural and Biological Considerations. American Psychological Association, Psychological Bulletin, v. 135, n. 2, p. 218-261, 2009.

CONSELHO NACIONAL DE DESENVOLVIMENTO CIENTÍFICO E TECNOLÓGICO (CNPq). Diretório de Grupos de Pesquisa (DGP). Número de mulheres cientistas já iguala o de homens, 2013. Disponível em: <http://www.cnpq.br/web/guest/noticiasviews//journal_content/56_INSTANCE_a6MO/10157/905361 >. Acesso em: 30 jul. 2016.

CONNELL, R. Gênero: uma perspectiva global. São Paulo: nVersos, 2015. 335 p.

D’AGORD, M. A negação lógica e a lógica do sujeito. Ágora, v. IX, n. 2, p. 241-258, julho/dezembro 2006.

DAUDER, S. G.; SEDEÑO, E. P. Las 'mentiras' científicas sobre las mujeres. Madrid: Catarata, 2017.

FÁVERO, M. H. Psicologia do gênero: Psicobiografia, Sociocultura e Transformações. Curitiba: Editora UFPR, 2010.

FREIRE, P. Professora sim, tia não: cartas a quem ousa ensinar. São Paulo: Editora Olho d’Água, 1994. 
JOEL, D. et al. Sex beyond the genitalia: The human brain mosaic. PNAS, v. 112, n. 50, 2015. Disponível em: <www.pnas.org/cgi/doi/10.1073/pnas.1509654112>. Acesso em: 07 set. 2017.

JOEL, D. Male or female? Brains are intersex. Frontiers in Integrative Neuroscience, v. 5, n. 57, 2011. Disponível em: <https://www.ncbi.nlm.nih.gov/pmc/articles/PMC3176412/>. Acesso em: 07 set. 2017.

JUNQUEIRA, R. D. A homofobia não é um problema. Aqui não há gays nem lésbicas: Estratégias discursivas e estados de negação da discriminação por orientação sexual e identidade de gênero nas escolas. Revista de Psicologia da UNESP, v. 9, n. 1, p. 123-139, 2010.

LERNER, G. The Creation of Feminist Consciousness: From the Middle Ages to Eighteen-Seventy. Nova lorque: Oxford University Press, 1993.

LIMA, B. S. O labirinto de cristal: as trajetórias das cientistas na Física. Revista Estudos Feministas, v. 21, n. 3, p. 883-903, 2013. Disponível em: <http://www.scielo.br/pdf/ref/v21n3/07.pdf>. Acesso em: 09 set. 2017.

LOURO, G. L. Mulheres na sala de aula. In: Priore, M. D. História das mulheres no Brasil. São Paulo, Contexto, 1997, p. 443-481.

LÖWY, I. Ciências e gênero. In: HIRATA, H. et al. (Org.). Dicionário crítico do feminismo. São Paulo: Editora UNESP, 2009.

MEIHY, J. C. S. B. Oral History in Brazil: Development and Challenges. Oral History Review. v. 26, p. 127-136, 1999.

Os novos rumos da História Oral: o caso brasileiro. Revista de História. n. 155, p. 191-203, 2006.

MEIHY, J. C. S. B.; HOLANDA, F. História Oral: como fazer, como pensar. São Paulo: Contexto, 2013.

MOSCHKOVICH, M.; ALMEIDA, A. M. F. de. As chances das mulheres na universidade. Revista Fapesp. Disponível em: <http://revistapesquisa.fapesp.br/wpcontent/uploads/2015/12/040-043_P_G\%C3\%AAnero_238.pdf?809ff8>. Acesso em: 24 jun. 2016.

NICHOLSON, L. Interpretando o gênero. Revista Estudos Feministas, v. 8, n. 2, p. 9-41, 2000.

PARREIRAS-E-SILVA, L. T. et al. Functional New World monkey oxytocin forms elicit an altered signaling profile and promotes parental care in rats. Proceedings of the National Academy of Sciences (PNAS), v. 114, n. 34. Disponível em: <www.pnas.org/cgi/doi/10.1073/pnas.1711687114>. Acesso em: 16 set. 2017.

PERROT, M. Práticas da memória feminina. Revista Brasileira de História, v. 9, n. 18, p. 09-18, 1989.

As mulheres ou os silêncios da história. Bauru: EDUSC, 2005.

Minha história das mulheres. Trad. Angela M. S. Corrêa. São Paulo: Contexto, 
QUEIROZ, M. I. P. de. Relatos Orais: do "indizível" ao "dizível". In: SIMSON, O. M. V. Experimentos com Histórias de Vida (Itália-Brasil). São Paulo: Vértice, 1988.

RABELO, A. O.; MARTINS, A. M. A mulher no magistério brasileiro: um histórico sobre a feminização do Magistério. In: CONGRESSO LUSO-BRASILEIRO DE HISTÓRIA DA EDUCAÇÃO, 4, Uberlândia, 2010. Anais. Aveiro: FCT, 2010. p. 6167-6176. Disponível em: <http://www2.faced.ufu.br/colubhe06/anais/arquivos/556AmandaO.Rabelo.pdf>. Acesso em: 07 set. 2017.

RATINAUD, P.; DEJEAN, S. Interface de R pour les Analyses Multidimensionnelles de Textes et de Questionnaires (IRAMUTEQ). Laboratoire LERASS. Versão 0.6, alpha 3, 2008.

RIBEIRO, D. O que é lugar de fala? Belo Horizonte: Letramento: Justificando, 2017.

Beauvoir explica: O fenômeno da reificação das mulheres na mídia brasileira. Sapere Aude, Belo Horizonte, v.3, n.6, p.489-492, 2012.

Para além da biologia: Beauvoir e a refutação do sexismo biológico. Sapere Aude, Belo Horizonte, v.4, n.7, p.506-509, 2013.

RODOVALHO, A. M. O cis pelo trans. Revista Estudos Feministas, v. 25, n. 1, p. 365-373, 2017. Disponível em: <http://www.scielo.br/scielo.php?pid=S0104026X2017000100365\&script=sci_arttext\&tIng=pt>. Acesso em: 10 dez. 2017.

SCHIEBINGER, L. O feminismo mudou a ciência? Trad. Raul Fiker. Bauru: EDUSC, 2001.

SCOTT, J. Gênero: Uma categoria útil de análise histórica. Educação \& Realidade. v. 20, n. 2, p. 71-99, 1995.

SOUSA, C. P. et al. Memória e autobiografia: formação de mulheres e formação de professoras. Revista Brasileira de Educação, 1996. Disponível em: <https://www.researchgate.net/publication/283212791_Memoria_e_autobiografia_formacao_ de_mulheres_e_formacao_de_professoras>. Acesso em: 22 mar. 2018.

TELES, M. A. de A. Breve história do feminismo no Brasil e outros ensaios. São Paulo: Alameda, 2017.

TILLY, L. A. Gênero, história das mulheres e história social. Trad. Ricardo Augusto Vieira. Cadernos Pagu, v. 3, p. 29-62, 1994.

UNITED NATIONS EDUCATIONAL, SCIENTIFIC AND CULTURAL ORGANIZATION (UNESCO). Unesco Science Report: Towards 2030. UNESCO Publishing, 2015. Disponível em: <http://unesdoc.unesco.org/images/0023/002354/235406e.pdf>. Acesso em: 20 mai. 2016.

VOZERIA. Direção: Raphaela Comisso: Brasil, 2015. 1 DVD (55 min).

WORLD ECONOMIC FORUM (WEF). The Global Competitiveness Report, 2017. Disponível em: <https://www.weforum.org/reports/the-global-competitiveness-report-20172018>. Acesso em: 01 dez. 2017.

Global Gender Gap Report, 2017. Disponível em: <http://reports.weforum.org/global-gender-gap-report-2017/dataexplorer/\#economy=BRA>. Acesso em: 01 dez. 2017. 


\section{ANEXOS}

\section{Anexo 1}

\section{Documento de autorização de uso do conteúdo das entrevistas}

Todos foram assinados pelas entrevistadas e encontram-se arquivados. Não os exibimos devido ao compromisso de sigilo com as entrevistadas.

\section{AUTORIZAÇÃO}

Eu, , autorizo a utilização do conteúdo da entrevista por mim concedida em e em a Renata Rosenthal, para o desenvolvimento de sua pesquisa de Mestrado.

Todas as informações serão tratadas com sigilo total.

de de 2017.
Cidade
dia
mês

Renata Rosenthal

Assinatura da entrevistada 


\section{Anexo 2}

\section{Cientistas citadas neste trabalho}

Alice Augusta Ball (1892-1916) era estadunidense e química. Desenvolveu um óleo injetável que foi o método mais eficiente para o tratamento da lepra ou hanseníase até os anos 1940. Foi também a primeira mulher e a primeira negra a se graduar na Universidade do Havaí e a obter um Mestrado.

Fonte: Wikipedia. Disponível em: <https://pt.wikipedia.org/wiki/Alice_Ball>. Acesso em: 10 dez. 2017.

Annie Jump Cannon (1863-1941) era estadunidense e astrônoma. Seu trabalho foi importante para a atual classificação das estrelas baseada em suas temperaturas. Classificou mais de 300 mil corpos estelares.

Fonte: Wikipedia. Disponível em: <https://pt.wikipedia.org/wiki/Annie_Jump_Cannon>. Acesso em: 10 dez. 2017.

Enedina Alves Marques (1913-1981) era brasileira e engenheira. Formou-se em Engenharia Civil em 1945 pela UFPR e foi a primeira mulher a se formar em Engenharia no estado e a primeira engenheira negra do Brasil. A Usina Capivari-Cachoeira, o Colégio Estadual do Paraná e a CEU - Casa do Estudante Universitário de Curitiba foram alguns de seus maiores trabalhos como engenheira.

Fonte: Wikipedia. Disponível em: <https://pt.wikipedia.org/wiki/Enedina_Alves_Marques>. Acesso em: 10 dez. 2017.

Grace Murray Hopper (1906-1992), norteamericana e analista de sistemas da Marinha dos Estados Unidos nas décadas de 1940 e 1950, também foi almirante. Ela criou o primeiro compilador e a primeira linguagem de programação de computadores próxima da linguagem humana.

Fonte: Wikipedia. Disponível em: <https://pt.wikipedia.org/wiki/Grace_Hopper>. Acesso em: 10 dez. 2017.

Joan Roughgarden (1946-) é americana, mulher trans e bióloga. Escreveu mais de cem obras. É conhecida por suas críticas à teoria da seleção sexual de Charles Darwin. 
Juliana Rotich (1977-) é do Quênia, negra e profissional de Tecnologia da Informação. Desenvolveu ferramentas web para tópicos relacionados ao meio ambiente. Também é autora de artigos, blogueira, palestrante e ficou conhecida por suas reflexões sobre tecnologia na África, expressando preocupações com a perda de áreas indígenas de captação de água e florestas no Quênia.

Fonte: Wikipedia. Disponível em: <https://en.wikipedia.org/wiki/Juliana_Rotich>. Acesso em: 10 dez. 2017.

Nagwa Abdel Meguid é egípcia e geneticista, vencedora do Prêmio L'Oreal UNESCO para Mulheres na Ciência, África e Oriente Médio. Sua pesquisa estudou mutações genéticas que causam síndromes conhecidas, como o autismo. Não foram encontrados registros do ano em que nasceu.

Fonte: Wikipedia. Disponível em: <https://en.wikipedia.org/wiki/Nagwa_Abdel_Meguid>. Acesso em: 10 dez. 2017.

Nise da Silveira (1905-1999) era brasileira e médica psiquiatra, aluna de Carl Jung. Era radicalmente contrária às formas que julgava serem agressivas em tratamentos de sua época, como o confinamento em hospitais psiquiátricos, eletrochoque, insulinoterapia e lobotomia.

Fonte: Wikipedia. Disponível em: <https://pt.wikipedia.org/wiki/Nise_da_Silveira>. Acesso em: 10 dez. 2017.

Rosalind Franklin (1920-1958) era britânica e química. Seu trabalho foi essencial para a compreensão dos modelos de estruturas do DNA, RNA, vírus, carvão e grafite como conhecemos hoje. Ela utilizava espectroscopia de raio-x em seus experimentos.

Fonte: Wikipedia. Disponível em: <https://en.wikipedia.org/wiki/Rosalind_Franklin>. Acesso em: 10 dez. 2017.

Stephanie Louise Kwolek (1923-2014) era polaco-estadunidense e química, inventora da fibra designada como Kevlar, de alta resistência mecânica, podendo atingir mais de cinco vezes a resistência do aço. Atualmente, o Kevlar é empregado na fabricação de coletes à prova de balas e equipamento de segurança.

Fonte: Wikipedia. Disponível em: <https://pt.wikipedia.org/wiki/Stephanie_Kwolek>. Acesso em: 10 dez. 2017. 


\section{Anexo 3}

\section{Desenhos elaborados pelas crianças na pesquisa feita em paralelo ao Mestrado}

Os exemplos estão agrupados segundo os Quadros 8 a 11 mostrados a seguir.

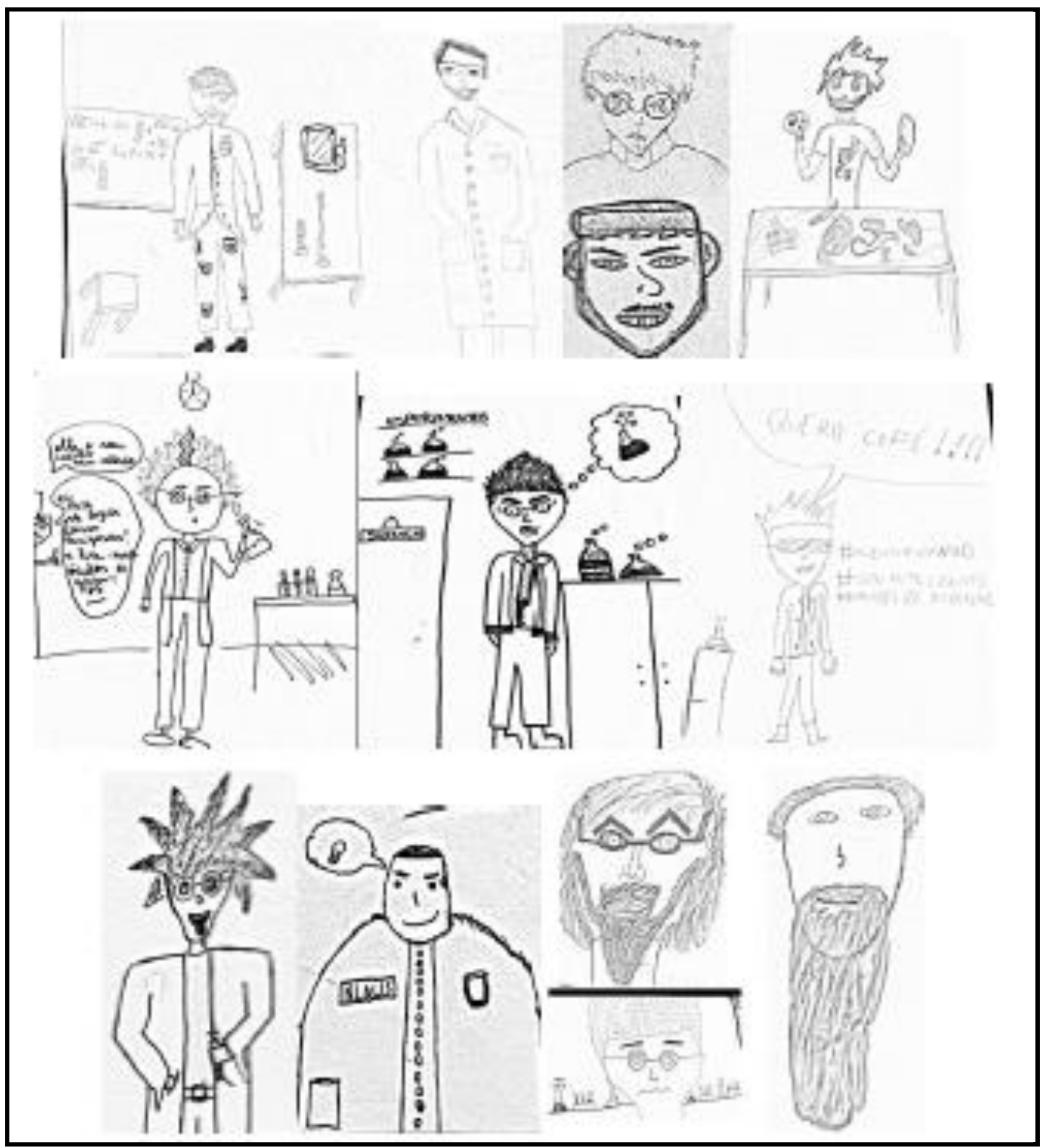

Quadro 8: Exemplos de desenhos elaborados pelos alunos, nos quais o cientista é um homem com fisionomia "brava", "séria", "agressiva" ou "louca", de jaleco, em ambiente de laboratório, com objetos nas mãos que indicam experimentos. 


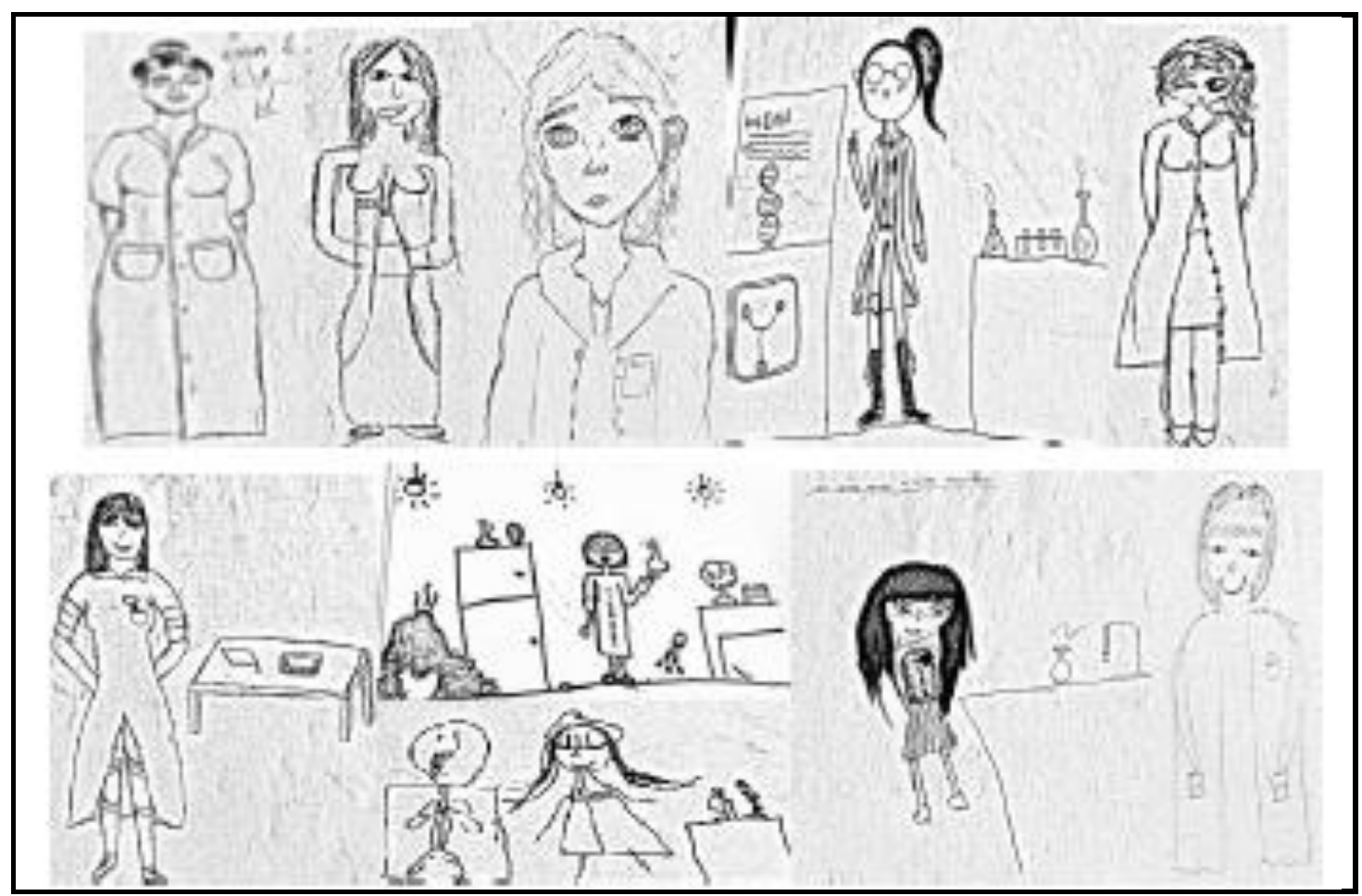

Quadro 9: Exemplos de desenhos elaborados pelas crianças, nos quais a cientista é mulher, em que se expressam alguns de seus estereótipos sobre cientistas.

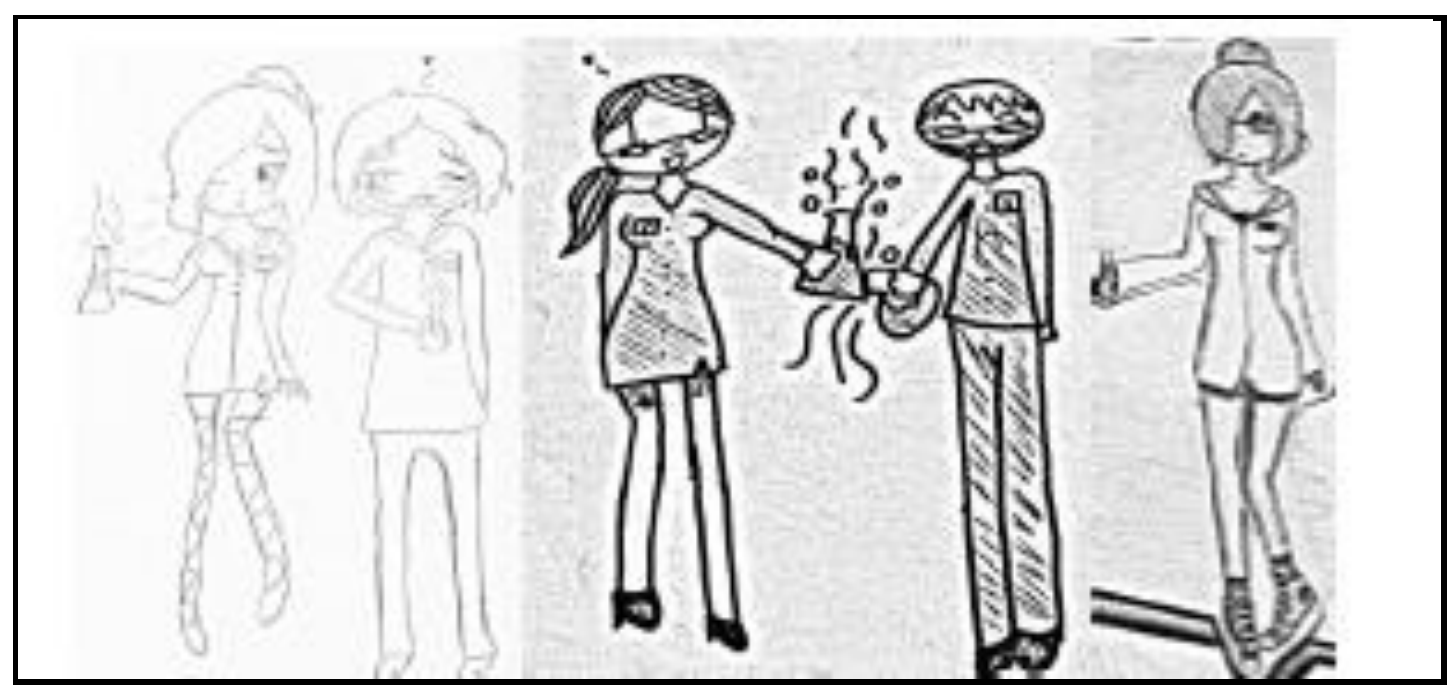

Quadro 10: Exemplos de desenhos elaborados pelos alunos nos quais as mulheres são assistentes do cientista. No caso da primeira ilustração (da esquerda para a direita), está escrito nos bolsos dos jalecos "assistente" e "chefe". Na segunda figura, a criança relatou que se tratava do mesmo caso. $\mathrm{Na}$ terceira, a criança havia feito como no primeiro, mas depois que foi apresentada "a resposta", ela pediu o desenho, destacou o homem, riscou o "assistente" do bolso da moça e o entregou novamente. Vale salientar a sexualização do corpo das assistentes: todas com saias curtas e com certa sensualidade. 


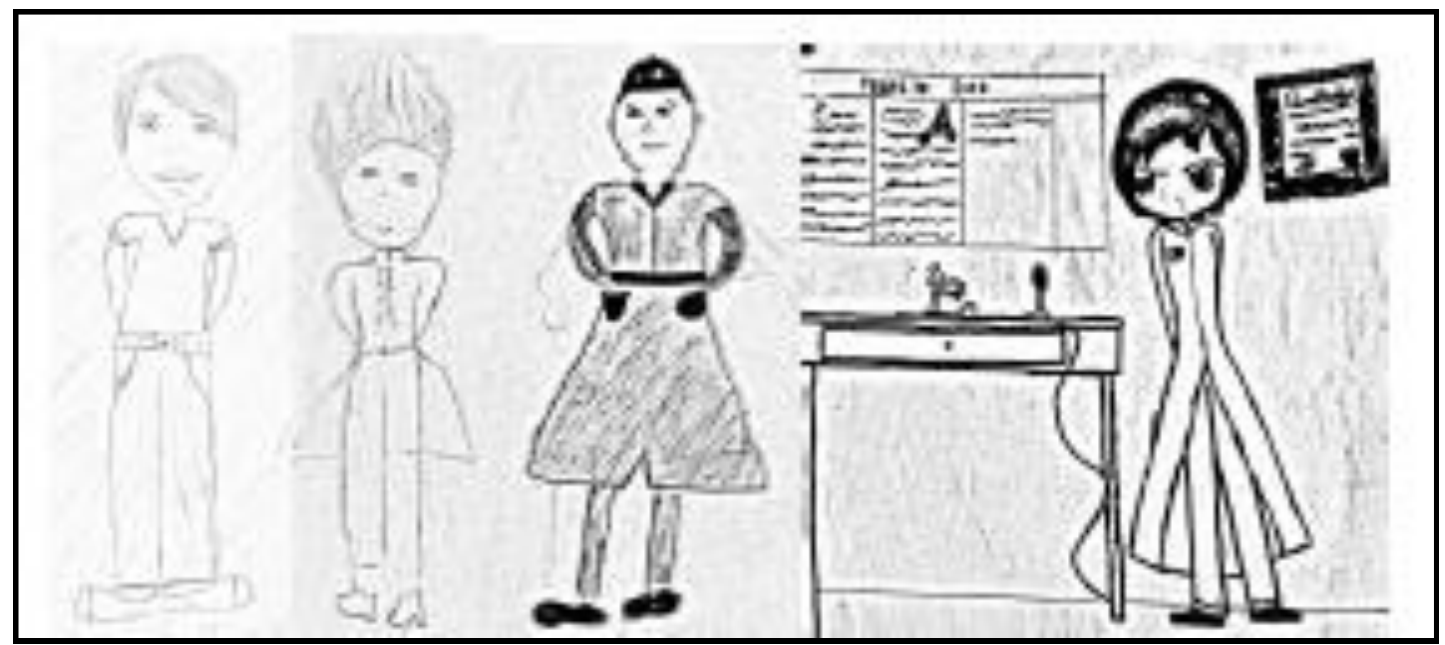

Quadro 11: Exemplos de desenhos nos quais o cientista não tem gênero definido. Nesses casos foi perguntado: "você pensou se o cientista era um homem ou uma mulher?". 